\title{
AVALIAÇÃO DO PROCESSO DE REPARAÇÃO TECIDUAL EM ÚLCERAS CRÔNICAS UTILIZANDO CURATIVOS DE CELULOSE BACTERIANA ASSOCIADOS OU NÃO À LASERTERAPIA
}

\begin{abstract}
Dissertação de mestrado apresentada ao Programa de Pós-Graduação Interunidades Bioengenharia - Escola de Engenharia de São Carlos / Faculdade de Medicina de Ribeirão Preto / Instituto de Química de São Carlos da Universidade de São Paulo como parte dos requisitos para a obtenção do título de Mestre em Ciências.
\end{abstract}

Área de Concentração: Bioengenharia

Orientadora: Profạ. Drª. Ana Maria Minarelli Gaspar

São Carlos,

2012 
AUTORIZO A REPRODUÇÃO E DIVULGAÇÃO TOTAL OU PARCIAL DESTE TRABALHO, POR QUALQUER MEIO CONVENCIONAL OU ELETRÔNICO, PARA FINS DE ESTUDO E PESQUISA, DESDE QUE CITADA A FONTE.

Ficha catalográfica preparada pela Seção de Tratamento da Informação do Serviço de Biblioteca - EESC/USP

Sanchez, Fernanda

S211a Avaliação do processo de reparação tecidual em úlceras crônicas utilizando curativos de celulose bacteriana associados ou não à laserterapia. / Fernanda Sanchez; orientadora Ana Maria Minarelli Gaspar. -- São Carlos, 2012 .

Dissertação (Mestrado-Programa de Pós-Graduação de Interunidades em Bioengenharia e Área de Concentração em Bioengenharia) -- Escola de Engenharia de São Carlos, Faculdade de Medicina de Ribeirão Preto; Instituto de Química de São Carlos da Universidade de São Paulo, 2012.

1. Celulose. 2. Úlcera. 3. Própolis. 4. Laser. I. Título. 


\title{
FERNANDA SANCHEZ
}

Título: "Avaliação do processo de reparação tecidual em úlceras crônicas utilizando curativos de celulose bacteriana associados ou não à laserterapia"

\begin{abstract}
DISSERTAÇÃO APRESENTADA AO PROGRAMA DE PÓS-GRADUAÇÃO INTERUNIDADES BIOENGENHARIA EESC/FMRPIIQSC DA UNIVERSIDADE DE SÃO PAULO PARA OBTENÇÃO DO TÍTULO DE MESTRE EM CIÊNCIAS NA ÁREA DE BIOENGENHARIA.
\end{abstract}

Aprovado (a) em: $23,10 / 20 / 2$

PROFa. DR ${ }^{a}$. ANA MARIA MINARELLI GASPAR (ORIENTADORA)

Resultado: APROVADA

PROF. DR. MAURICIO FERRAZ DE ARRUDA

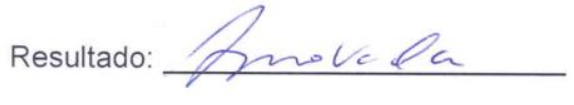

PROFa. DR ${ }^{a}$. SYBELE SASKA SPECIAN

Resultado:

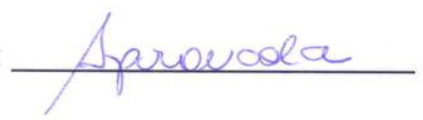

Universidade Estadual Paulista "Júlio de Mesquita Filho" - UNESP

Assinatura:

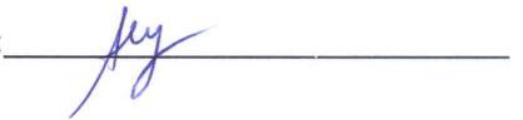

IMES FAFICA - Instituto Niunicipal de Ensino Superior de Catanduva

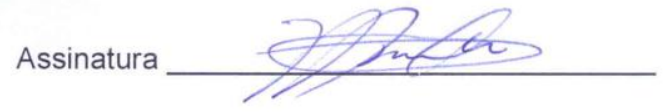

Universidade Estadual Paulista "Júlio de Mesquita Filho" - UNESP

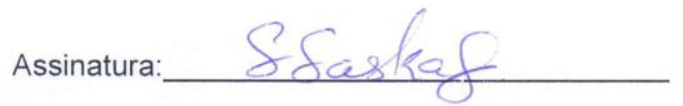


Este trabalho é dedicado a todos os membros de minha família, que juntos formam a base para a sustentação de todo o meu conhecimento. 


\section{AGRADECIMENTOS}

À minha orientadora, amiga e exemplo de profissional $\operatorname{Prof}^{\mathrm{a}}{ }^{\mathrm{Dr}}{ }^{\mathrm{a}}$ Ana Maria Minarelli Gaspar, que me deu essa grande oportunidade, com quem aprendi tudo sobre a pesquisa e que me deu força pra continuar.

À colega Dra. Sybele Saska, pela grande ajuda e muitos ensinamentos.

Às empresas Fibrocel e Apis Flora, pelas membranas de CB e extrato de própolis, respectivamente.

Ao Pós-doutorando Hernane Barud pelo tempo dedicado ao meu trabalho e muitas ideias.

Ao Dr. Hermes Pretel e à DMC pelo fornecimento do aparelho de laser.

Aos alunos do Laboratório de Materiais Fotônicos do Instituto de Química da UNESP de Araraquara e ao Prof Sidney Ribeiro pelo espaço cedido.

Ao aluno João Vitor pelo auxílio com a produção das membranas.

Aos grandes amigos do programa Interunidades Bioengenharia de São Carlos pela amizade e por tornarem a vida de pós-graduando mais divertida.

Aos meus queridos pacientes que confiaram em meu trabalho e por quem tenho muito carinho, devo muito à eles.

Ao Lar São Francisco de Assis e Vila Vicentina pela recepção carinhosa.

À Fundação de Amparo à Pesquisa do Estado de São Paulo- FAPESP, pelo auxílio financeiro.

Às melhores pessoas que eu conheço na vida, meus pais Sérgio e Leida, pelo maior incentivo de todos para que eu iniciasse, me mantivesse firme e concluísse mais essa etapa da vida (todo o agradecimento do mundo ainda seria pouco perto do que vocês merecem).

Ao Saulo e Gabriela pelos bons exemplos e por trazer a luz.

Ao meu amigo-irmão Pico pelos anos de amizade, carinho e por ter me mostrado o caminho para a vida acadêmica.

À minha sogra e amiga Mariusa pelas preces, positividade e grande ajuda.

Ao meu marido e grande amor Fernando pela compreensão, paciência e imenso apoio na passagem desse árduo caminho. 
Por fim, porém de maior importância, ao meu filho Felipe, a razão do meu viver e por quem vale a pena continuar lutando, agradeço por me ensinar a ser uma pessoa melhor.

Meus sinceros agradecimentos às todas essas pessoas que contribuíram direta ou indiretamente para que este trabalho se concretizasse. 
“A sua profissão é privilégio e aprendizado (...) Toda pessoa que serve além do dever, encontrou 0 caminho para a verdadeira felicidade."

André Luiz 


\section{RESUMO}

SANCHEZ, F. Avaliação do Processo de Reparação Tecidual em Úlceras Crônicas Utilizando Curativos de Celulose Bacteriana Associados ou não à Laserterapia. 2012. 84 f. Dissertação de Mestrado. Programa de Pós-Graduação Interunidades Bioengenharia EESC/FMRP/IQSC Universidade de São Paulo, São Carlos, 2012.

Úlceras crônicas são algumas das principais causas de morbi-mortalidade, devido a sua alta probabilidade de infecção e sepse; por esse motivo, elas tem um impacto significativo na saúde pública e no dispêndio de recursos com assistência médica. Úlceras (ou feridas) são caracterizadas por uma perda de substância tecidual, provocando a descontinuidade do tecido cutâneo e adjacentes, alterando a estrutura anatômica e fisiológica das regiões afetadas. As mais comuns são: cirúrgicas, venosas (de estase, varicosa), arteriais, neurotróficas (hanseníase, diabetes, alcoolismo), por pressão ou mistas. A membrana de celulose bacteriana (CB) é utilizada como curativo temporário para tratamento dessas úlceras de pele de diversas origens, devido à excelente conformação no corpo, manutenção da umidade local, redução da dor e aceleração da regeneração do epitélio. A própolis tem mostrado possuir efeitos antibacteriano, antifúngico, antiviral, anti-inflamatório, hepatoprotetor, antioxidante, antitumoral e imunomodulatórios. Outro tratamento para úlceras muito utilizado é a laserterapia de baixa intensidade (LBI), cujos efeitos regenerativos são comprovados; além de promover a cicatrização de úlceras, promove o alívio da dor, melhora da circulação local e diminuição da inflamação. O objetivo deste trabalho foi avaliar a eficácia da aplicação de curativos temporários de CB pura ou com própolis associados ou não a aplicação de LBI em indivíduos que apresentavam úlceras crônicas. A amostra conteve 8 pacientes, num total de 12 úlceras, divididos aleatoriamente em 05 grupos: Grupo Membrana de CB Pura (G1), Grupo Membrana de CB com Própolis (G2), Grupo Laser (G3), Grupo Membrana de CB Pura + Laser (G4), Grupo de Membrana de CB com própolis + Laser (G5). Sessenta e sete por cento das úlceras tratadas evoluíram para cicatrização total, apresentando aumento da velocidade de cicatrização em comparação com o tempo de existência da úlcera. Do restante das úlceras tratadas, somente uma teve sua área final aumentada devido a fatores como diabetes descompensada e infecção bacteriana; as outras tiveram uma grande evolução e chegaram próximas da reepitelização total. Todos os tratamentos se mostraram efetivos no tratamento de úlceras crônicas, porém o diferencial na cura foi a utilização de membranas de CB pura e com própolis.

Palavras-chave: Celulose, Úlcera, Própolis, Laser. 


\begin{abstract}
SANCHEZ, F. Evaluation of the Tecidual Healing Process in Chronic Ulcers Using Bacterial Cellulose Curatives Associated or not to Lasertherapy. 2012. 84 f. Dissertação de Mestrado. Programa de Pós-Graduação Interunidades Bioengenharia EESC/FMRP/IQSC Universidade de São Paulo, São Carlos, 2012.
\end{abstract}

Chronic skin ulcers are a major source of morbidity-mortality due to their high probability of infection and sepsis; for this reason, they have a significant impact on public health and the expenditure of healthcare resources. Skin ulcers (or wounds) are characterized by a loss of tecidual substance, interrupting cutaneous tissue and changing their anatomic and physiologic structures. The most commom ulcers are: cirurgical, venous, arterials, neurotrophics, pressure ulcers or mixed factors. Bacterial cellulose $(\mathrm{BC})$ membrane is used as a temporary curative for the treatment of several types of skin ulcers due to its amazing body conformation, keeping the humidity, reducing the pain and accelerating the ephitelium healing process. Propolis have shown antimicrobial, antifungal, antiviral, anti-inflammatory, hepatoprotective, antioxidant, antitumor and immunity modulation effects. Another treatment for skin ulcers is low-level laser therapy (LLLT), who have regenerative effects, and it also promoves the ulcer cicatrization, pain relief, better local circulation and reduces the inflammation. The aim of this study was to evaluate the effectiveness of pure BC and propolis BC membrane curative application, associated or not to LLLT in individuals who had chronic ulcers. The sample contained 8 patients and 12 ulcers, randomly divided in 5 groups: Pure BC Membrane Group (G1), Propolis BC Membrane Group (G2), Laser Group (G3), Pure BC Membrane + Laser Group (G4) and Propolis BC Membrane + Laser (G5). Sixty seven per cent of the treated ulcers progressed to full cicatrization, increasing the speed of cicatrization when compared to the existent period of the ulcer. The resto of treated ulcers had a great evolution and got close to the total reepithelization, except for one that had increased its final area because of decompensated diabetes and bacterial infection. All treatments had shown effectiveness for the treatment of chronic skin ulcers, however the differential on healing process was the use of pure $\mathrm{BC}$ membranes and propolis $\mathrm{BC}$ membranes.

Key words: Cellulose, Skin ulcers, Propolis, Laser. 


\section{LISTA DE ILUSTRAÇÕES}

Figura 1: Principais diferenças entre úlceras venosas e úlceras arteriais (Furtado 2003)

Figura 2: Classificação das úlceras crônicas quanto a sua profundidade (European Pressure Ulcer Advisory Panel, 1999).

Figura 3: Estrutura linear da celulose. As linhas pontilhadas esquematizam as possíveis ligações de hidrogênio (DONINI et al, 2010).

Figura 4: Microscopia eletrônica de varredura (MEV) da organização microfibrilar da celulose sintetizada pela Gluconacetobacter xylinus.

Figura 5: Demonstração de uma cultura da Gluconacetobacter xylinus. 30

Figura 6: CB hidratada .30

Figura 7: Manta de CB úmida após purificação. 31

Figura 8: Membrana de CB pura seca (demonstração de sua transparência)..........31

Figura 9: Membrana de CB úmida imersa em solução de EPP a 2,4\%. 32

Figura 10: Membrana com própolis seca (demonstração de sua transparência) .....32

Figura 11: Comparação entre membrana de CB pura e com própolis. .33

Figura 12: Aparelho Flash Lase I. 33

Figura 13: Figura demonstrativa da colocação da membrana sobre a úlcera. 35

Figura 14: Demonstração da aplicação do LBI. 35

Figura 15: Visor do potenciômetro durante a análise. 37

Figura 16: Demonstração da análise da membrana de CB (própolis).....

Figura 17: Posicionamento da caneta do laser na região central do fotodetector....37

Figura 18: Foto inicial (G1a) .40

Figura 19: Após 15 dias de tratamento (G1a). .41

Figura 20: Após cerca de 30 dias de tratamento. .41

Figura 21: Foto inicial (G1b) 42

Figura 22: Após cerca de 7 dias do início do tratamento (G1b)..... .43 
Figura 23: Cerca de 15 dias após início do tratamento .43

Figura 24: Reepitelização total em 24 dias..................................................44

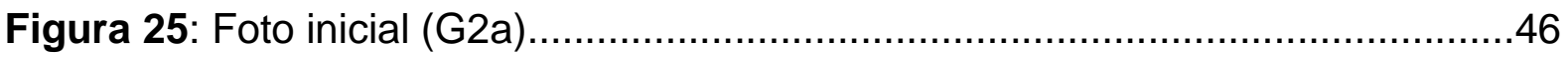

Figura 26: 7 dias após início do tratamento (G2a) ....................................46

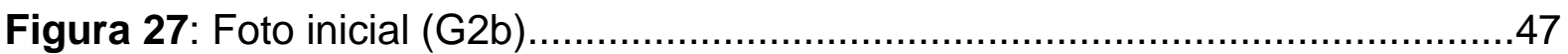

Figura 28: Após 7 dias do início do tratamento, fechamento de G2b e aparecimento

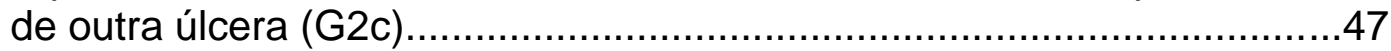

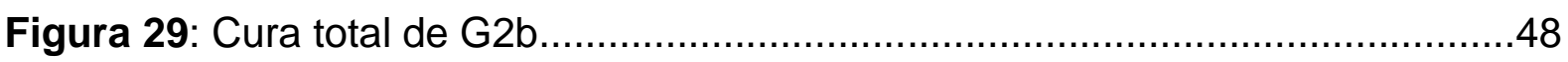

Figura 30: Análise da área inicial de G2c................................................48

Figura 31: Reepitelização total de G2c em 7 dias ........................................49

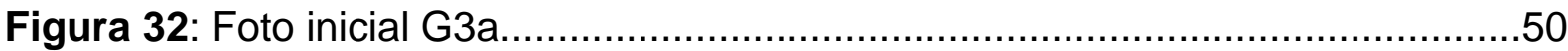

Figura 33: Após 7 dias do início das aplicações (G3a) ...................................50

Figura 34: Após 15 dias do início das aplicações (G3a).................................51

Figura 35: Após 30 dias do início das aplicações (G3a) ..................................

Figura 36: 60 dias após o início das aplicações (G3a)..................................51

Figura 37: 90 dias após início das aplicações (G3a) .....................................52

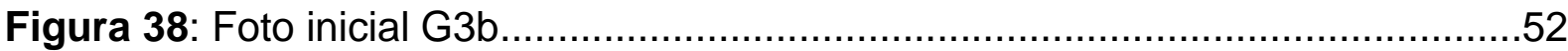

Figura 39: Após 7 dias do início do tratamento (G3b) ......................................53

Figura 40: Após cerca de 20 dias do início do tratamento..................................53

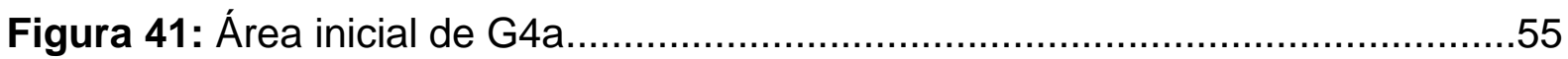

Figura 42: Após 7 dias do início do tratamento................................................55

Figura 43: Após 15 dias do início do tratamento...................................................56

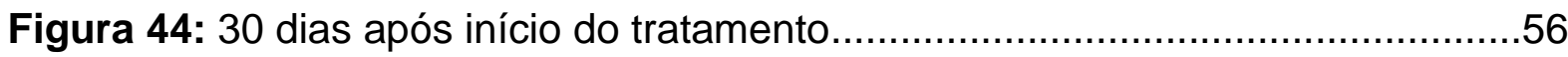

Figura 45: Aproximadamente 60 dias após início do tratamento...........................57

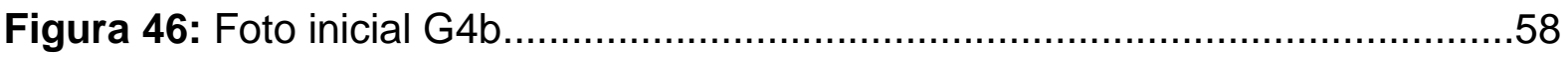




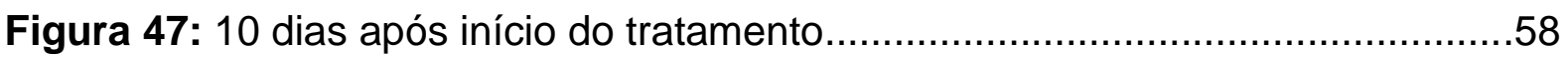

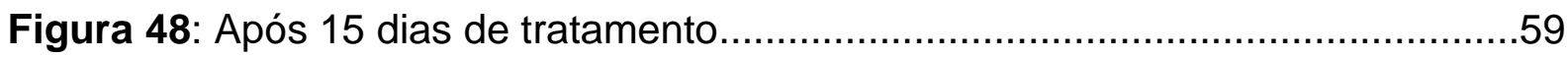

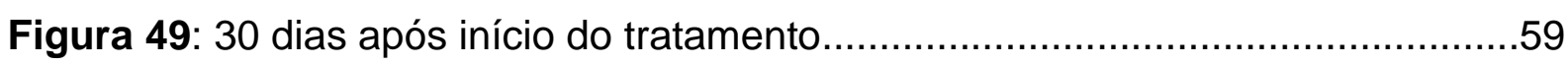

Figura 50: 60 dias após início do tratamento....................................................59

Figura 51: Aproximadamente 90 dias após início do tratamento, cura total.............60

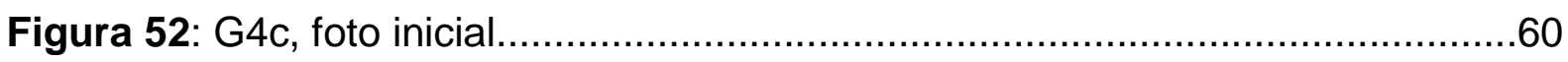

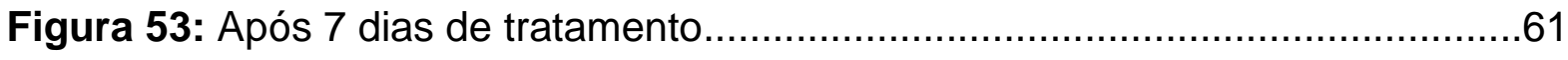

Figura 54: 15 dias após inicio do tratamento......................................................

Figura 55: Após 30 dias do início do tratamento................................................62

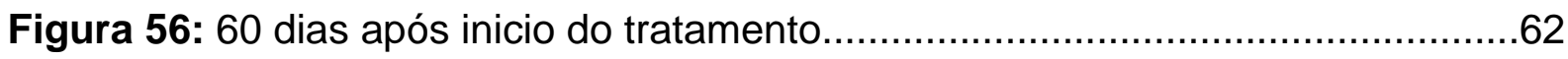

Figura 57: 90 dias do inicio do tratamento......................................................63

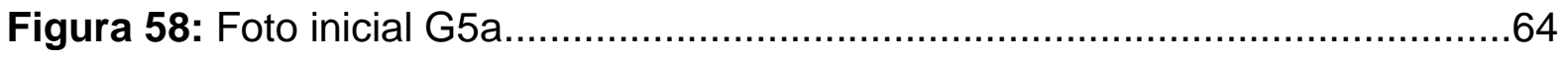

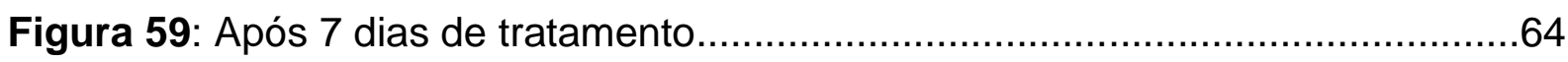

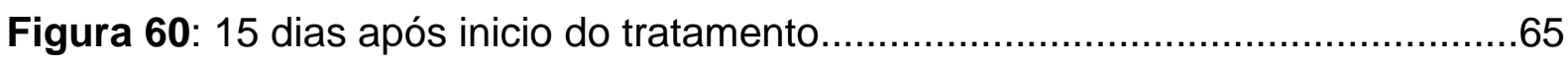

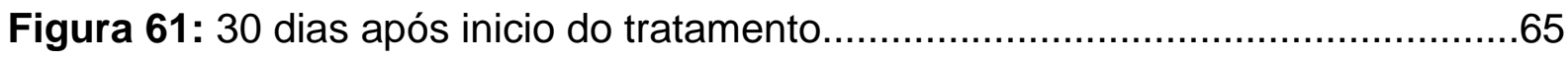

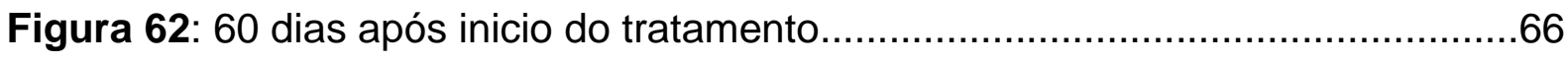

Figura 63: 90 dias após inicio do tratamento, cicatrização total................................66

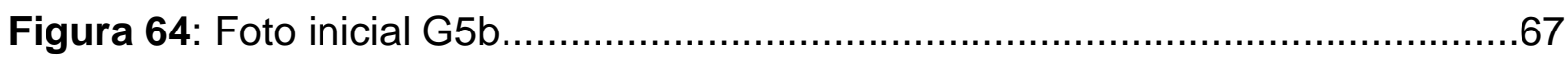

Figura 65: Cerca de 7 dias após inicio do tratamento...........................................67

Figura 66: 15 dias após inicio do tratamento.......................................................68

Figura 67: 30 dias após inicio do tratamento.........................................................68

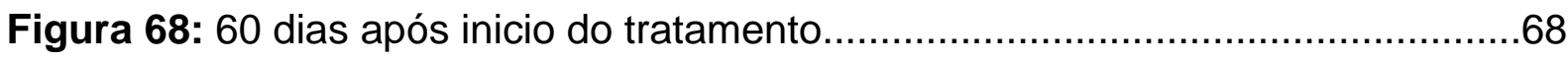

Figura 69: 75 dias após inicio do tratamento...................................................69 


\section{LISTA DE TABELAS}

Tabela 1 - Divisão dos grupos de tratamento e procedimentos. .34

Tabela 2 - Dados do teste de absorbância do laser através das membranas de CB pura e com própolis.

Tabela 3 - Demonstração dos resultados da experimentação. ( $\left.{ }^{\star}\right)$ Aumento da área ulcerada. 


\section{LISTA DE ABREVIATURAS E SIGLAS}

ATP: Trifosfato de adenosina

CB: Celulose bacteriana

$\mathrm{Cm}^{2}$ : Centímetros quadrados

EPP: Extrato padronizado de própolis

G1: Grupo que recebeu aplicação da membrana de CB pura

G2: Grupo que recebeu aplicação da membrana de CB com Própolis

G3: Grupo que recebeu aplicação de laser

G4: Grupo que recebeu aplicação da membrana de CB pura associada ao laser

G5: Grupo que recebeu aplicação da membrana de CB com própolis associada ao laser

GaAs: Arseneto de Gálio

HeNe: Hélio-Neônio

ICU: Índice de Cicatrização de Úlceras

InGaAIP: Índio-Gálio-Alumínio-Fósforo

LBI: Laser de baixa intensidade

LLLT: Low-level laser therapy

MEV: Microscopia eletrônica de varredura

PTFE: Politetrafluoretileno

SF: Soro fisiológico

UP: Úlcera de pressão

$\beta$ : Beta 


\section{SUMÁRIO}

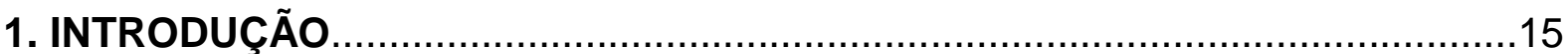

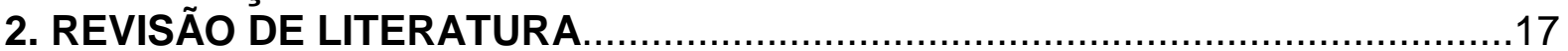

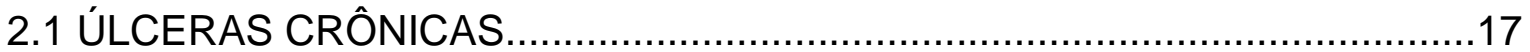

2.2 MEMBRANA DE CELULOSE BACTERIANA (CB) ................................21

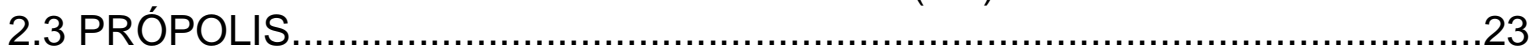

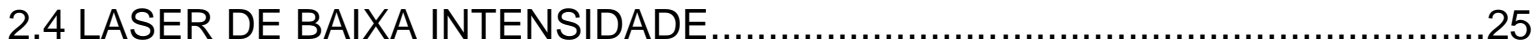

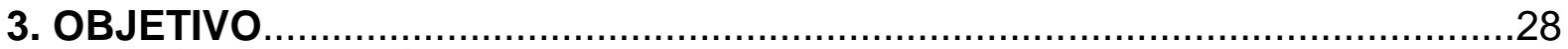

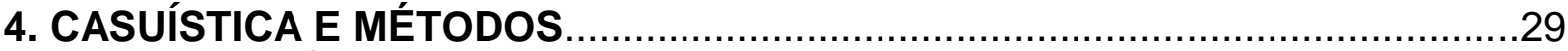

4.1 OBTENÇÃO DAS MEMBRANAS DE CB PURA E DE CB COM

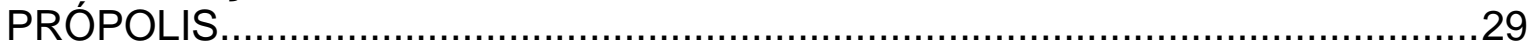

4.2 ESPECIFICAÇÕES DO LASER DE BAIXA INTENSIDADE ........................33

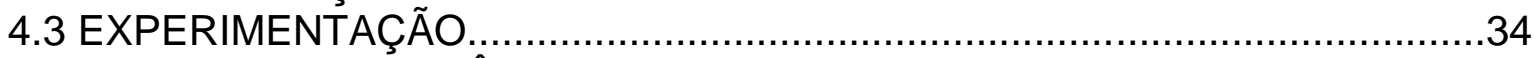

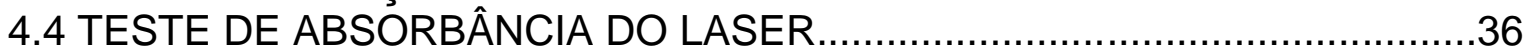

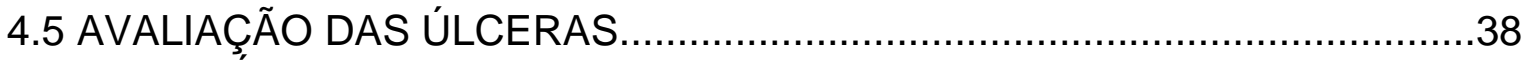

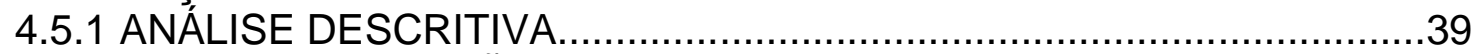

5. RESULTADOS E DISCUSSÃO

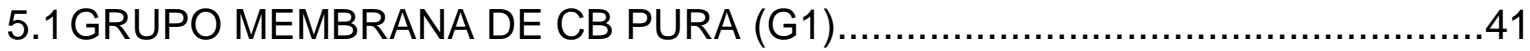

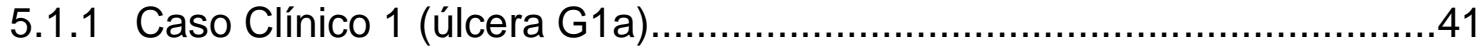

5.1.2 Caso Clínico 2 (úlcera G1b) ......................................................... 42

5.2 GRUPO MEMBRANA DE CB COM PRÓPOLIS (G2) .............................46

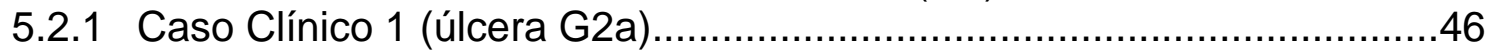

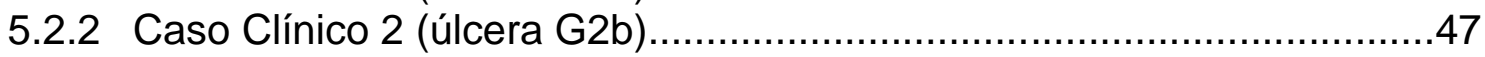

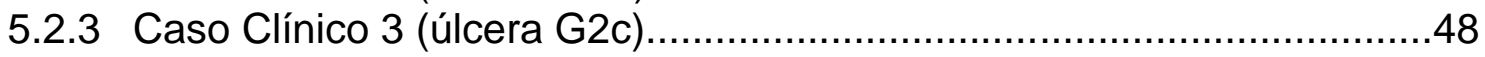

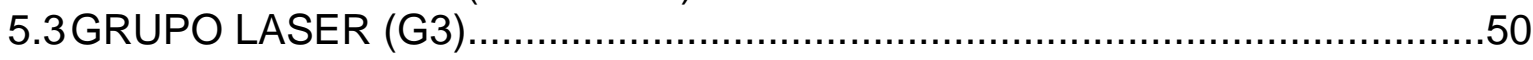

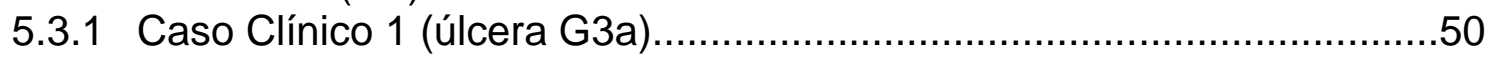

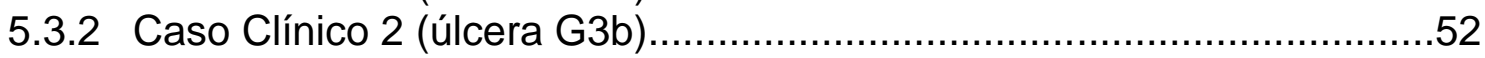

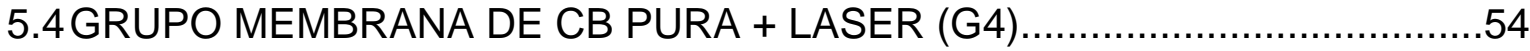

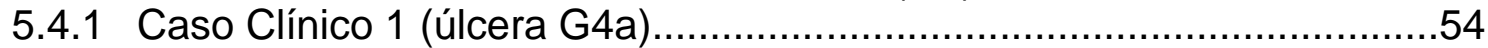

5.4 .2 Caso Clínico 2 (úlcera G4b) ........................................................ 58

5.4.3 Caso Clínico 3 (úlcera G4c) ............................................................60

5.5 GRUPO MEMBRANA DE CB PRÓPOLIS + LASER (G5) ..........................64

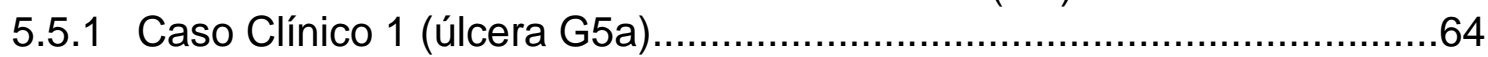

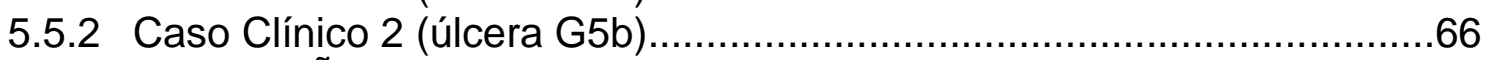

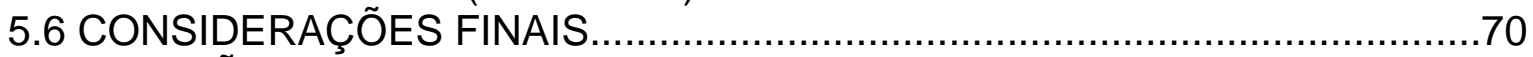

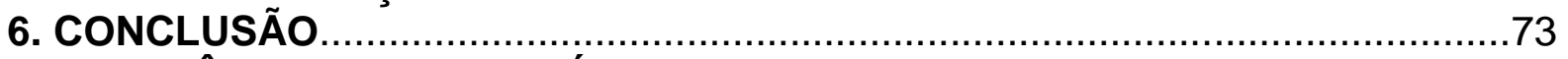

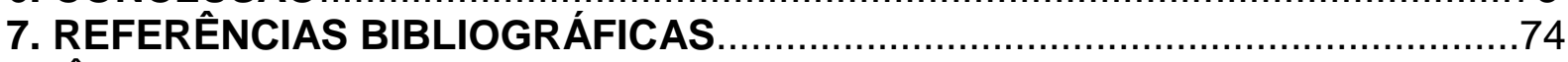

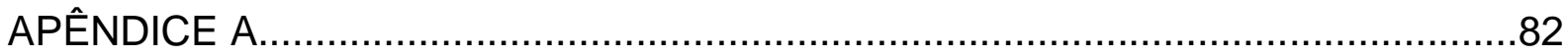

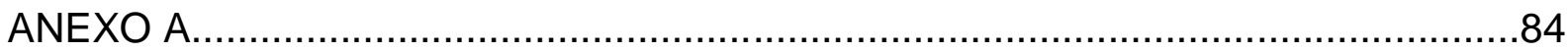




\section{INTRODUÇÃO}

Os gastos públicos para cuidados com a saúde apresentam considerável impacto no que tange o tratamento de úlceras crônicas. Atualmente essas úlceras apresentam alto nível de morbidade, ocasionando uma considerável inabilidade do paciente, e um aumento na taxa de mortalidade devido ao quadro de sepse (SAMSON; LEFEVRE; ARONSON, 2004).

Inúmeros são os tipos de curativos atualmente usados para tratamento das úlceras cutâneas, com diferentes indicações, vantagens e desvantagens. A escolha do curativo a ser utilizado deve ser baseada essencialmente em fatores como eficácia, segurança e custo, para que o paciente possa mantê-lo e, assim, conseguir um resultado satisfatório, pois as lesões apresentam uma cicatrização muito demorada na maioria dos casos (FRADE et al., 2011). Segundo Santos et al (2012), as coberturas temporárias mais utilizadas para tratamento dessas enfermidades cutâneas são: hidrogel, curativo com alginato de cálcio, filme de poliuretano, curativo de hidrocolóide, papaína, gaze impregnada de petrolato, gase impregnada de parafina, apósito absorvente, curativo com nanopartículas de prata, gase tradicional, etc, porém sua maioria possui alto custo financeiro e sua escolha depende de cada tipo de úlcera e de cada fase específica da cicatrização.

Os biomateriais podem ser definidos como substâncias de origem natural ou sintética que são toleradas de forma transitória ou permanente pelos diversos tecidos que constituem os órgãos dos seres vivos. Podem ser utilizados como um todo ou parte de um sistema que trata, restaura ou substitui algum tecido, órgão ou função do corpo, ou ainda como um material utilizado em um dispositivo médico, com intenção de interagir com sistemas biológicos. O estudo de biomateriais envolve o entendimento das propriedades, funções e estruturas dos tecidos biológicos, dos materiais sintéticos e da interação entre os mesmos (WILLIAMS; ALI; DOHERTY, 1994).

Dentre os biomateriais existentes para cobertura/tratamento de úlceras crônicas de pele, Czaja et al. (2007a) recomenda a utilização de curativos temporários de celulose bacteriana (CB) produzida pela Gluconacetobacter xylinus, pois podem ser aplicados em inúmeros tipos diferentes de úlceras de pele, têm uma excelente conformação no corpo do paciente, mantém o meio úmido, reduzem significativamente a dor, aceleram a reepitelização, reduzem a formação de 
cicatrizes, formam uma barreira mecânica contra microorganismos patogênicos e são considerados de baixo custo.

O poder curativo da membrana de celulose pode ser potencializado associando o extrato de própolis durante sua produção; isso ocorre devido característica bactericida desse componente natural. Estudos realizados por Eraslan, Kanbur, Silici (2007) e Newairy et al. (2009) também verificaram que a própolis possui outra vantagem que é sua capacidade antioxidativa.

A utilização de biomateriais associados ou não a Laserterapia de baixa intensidade (LBI) tem sido reportada como um dos recursos mais utilizados para auxiliar o processo de cicatrização de úlceras, atuando no alívio da dor, na melhora da circulação local e principalmente na diminuição do processo inflamatório exacerbado (YASUKAWA et al., 2007) .

Devido à gravidade dessas úlceras crônicas e seu impacto físico, social e financeiro na saúde de pacientes acometidos, este trabalho foi de grande valia para o desenvolvimento de novas técnicas de tratamento dessas enfermidades que apresentam dificuldade de cura quando submetidas a tratamentos tradicionais existentes na literatura atual. 


\section{REVISÃO DE LITERATURA}

\section{1 ÚLCERAS CRÔNICAS}

Úlceras (ou feridas) são caracterizadas por uma perda de substância tecidual, provocando a descontinuidade do tecido cutâneo e até mesmo subcutâneo, alterando a estrutura anatômica e fisiológica das estruturas afetadas (FRADE et al., 2012).

Frade et al. (2005) também descreveram que a cicatrização da úlcera é uma sequência de eventos biológicos complexos que envolvem processos moleculares e celulares, como recrutamento de leucócitos, inflamação, angiogênese, deposição de colágeno e reepitelização.

Giménez, Gutiérrez, Puya (2005) descreveram resumidamente os complexos mecanismos de cicatrização em três fases: inflamatória, proliferativa e de maturação. Na primeira fase, que pode durar até 72 horas, ocorre o tamponamento da úlcera (formação de coágulo) e sua limpeza; dela participam as plaquetas e células inflamatórias diferenciadas, principalmente neutrófilos e macrófagos. Também durante esta etapa é liberada uma série de mediadores químicos que iniciam o processo de cicatrização. Na segunda etapa, proliferativa, ocorre o incremento do colágeno e a angiogênese para constituir o tecido de granulação, e pode durar semanas; nesta etapa a participação das células endoteliais é de grande importância. A última etapa, de maturação, pode durar até anos e se baseia fundamentalmente na produção e amadurecimento/reorganização do colágeno. Em todas estas etapas há uma participação dos queratinócitos que tendem a migrar tanto das margens como dos restos epiteliais da úlcera, mediante sistemas de multiplicação e maturação.

Nas úlceras crônicas existem alterações dos mecanismos de cicatrização; assim, em estudos realizados a partir de exsudatos destas lesões, demonstrou-se um incremento dos níveis de metaloproteinases, que determina um aumento da atividade proteolítica e inativação de fatores de crescimento necessários para a cicatrização efetiva. Essas úlceras sofrem um fenômeno de estagnação em seus mecanismos de cicatrização, que as tornam incapazes de completá-lo; para esse tipo de úlcera, a intervenção através de diversas técnicas de tratamento é fundamental para conduzir à reparação (GIMÉNEZ; GUTIÉRREZ; PUYA, 2005). 
No estudo de Franks et al (1994) percebeu-se que as úlceras crônicas podem apresentar tempo de duração variando de 1 mês até 63 anos e elevada taxa de recorrência num curto espaço de tempo. Desta forma há o interesse crescente em estudar a incidência de recorrências (FURTADO, 2003).

Segundo Frade et al. (2012) as úlceras crônicas podem ser classificadas quanto à:

- Causa: cirúrgicas e não cirúrgicas;

- Profundidade: Grau I, Grau II, Grau III, Grau IV;

- Etiologia: venosas (de estase, varicosa), arteriais, neurotróficas (hanseníase, diabetes, alcoolismo), por pressão, mistas, causadas por traumas, neoplasias, infecções, paniculites, pioderma gangrenoso, etc.

A generalidade dos estudos indica que cerca de $70 \%$ de todas as úlceras de perna são de origem venosa, $10-20 \%$ de origem arterial e 10-15\% de etiologia mista (MORISON; MOFFATT, 1994). Segundo Callam et al. (1985), entre 1,5 a 3 indivíduos em cada 1000 têm uma úlcera de perna e a prevalência aumenta com a idade para 20 indivíduos em cada 1000 com mais de 80 anos.

As úlceras venosas ocorrem em indivíduos com doença venosa (insuficiência venosa), onde se verifica que a diminuição da pressão das veias mais profundas das pernas durante o exercício não é suficiente; ocorrendo assim uma hipertensão do sistema venoso. Embora se saiba que a ulceração venosa é causada por hipertensão venosa, o mecanismo preciso é ainda pouco claro (FURTADO, 2003).

Úlceras arteriais ocorrem, na maioria das vezes, devido à aterosclerose que é uma doença infamatória e degenerativa dos grandes vasos, onde se acumulam placas de colesterol, células e tecidos degradados, estreitando progressivamente o lumen do vaso. A aterosclerose está associada ao tabagismo, hipertensão, hiperlipidemia e diabetes. Outras causas de úlceras arteriais incluem tromboembolismo arterial, doença de Raynauds ou traumatismo (VOWDEN; VOWDEN, 1996).

As principais diferenças entre úlceras venosas e arteriais estão representadas na figura 1 (FURTADO, 2003); e a classificação das úlceras crônicas quanto a sua profundidade segundo a European Pressure Ulcer Advisory Panel (1999) está representada na figura 2. 


\begin{tabular}{|c|c|c|}
\hline Indicador & Venosa & Arterial \\
\hline Localização & Terço inferior da perna / maléolo medial & $\begin{array}{l}\text { Dedos, pé, calcâneo/lateral da } \\
\text { perna }\end{array}$ \\
\hline Evolução & Lenta & Rápida \\
\hline $\begin{array}{l}\text { Profundidade } \\
\text { leito, margens }\end{array}$ & $\begin{array}{l}\text { Superficial, leito vermelho vivo, margens } \\
\text { irregulares }\end{array}$ & $\begin{array}{l}\text { Profundo, } \\
\text { pálido, margens definidas }\end{array}$ \\
\hline Tamanho & Grande & Pequena \\
\hline Exsudato & Moderado, excessivo & Mínimo \\
\hline Edema & Presente & $\begin{array}{l}\text { Ausente, ou presente devido } \\
\text { estase }\end{array}$ \\
\hline Dor & Pouca ou moderada & Extrema \\
\hline Pulsos & Presente & Diminuídos ou ausente \\
\hline
\end{tabular}

Figura 1: Principais diferenças entre úlceras venosas e úlceras arteriais (FURTADO 2003)

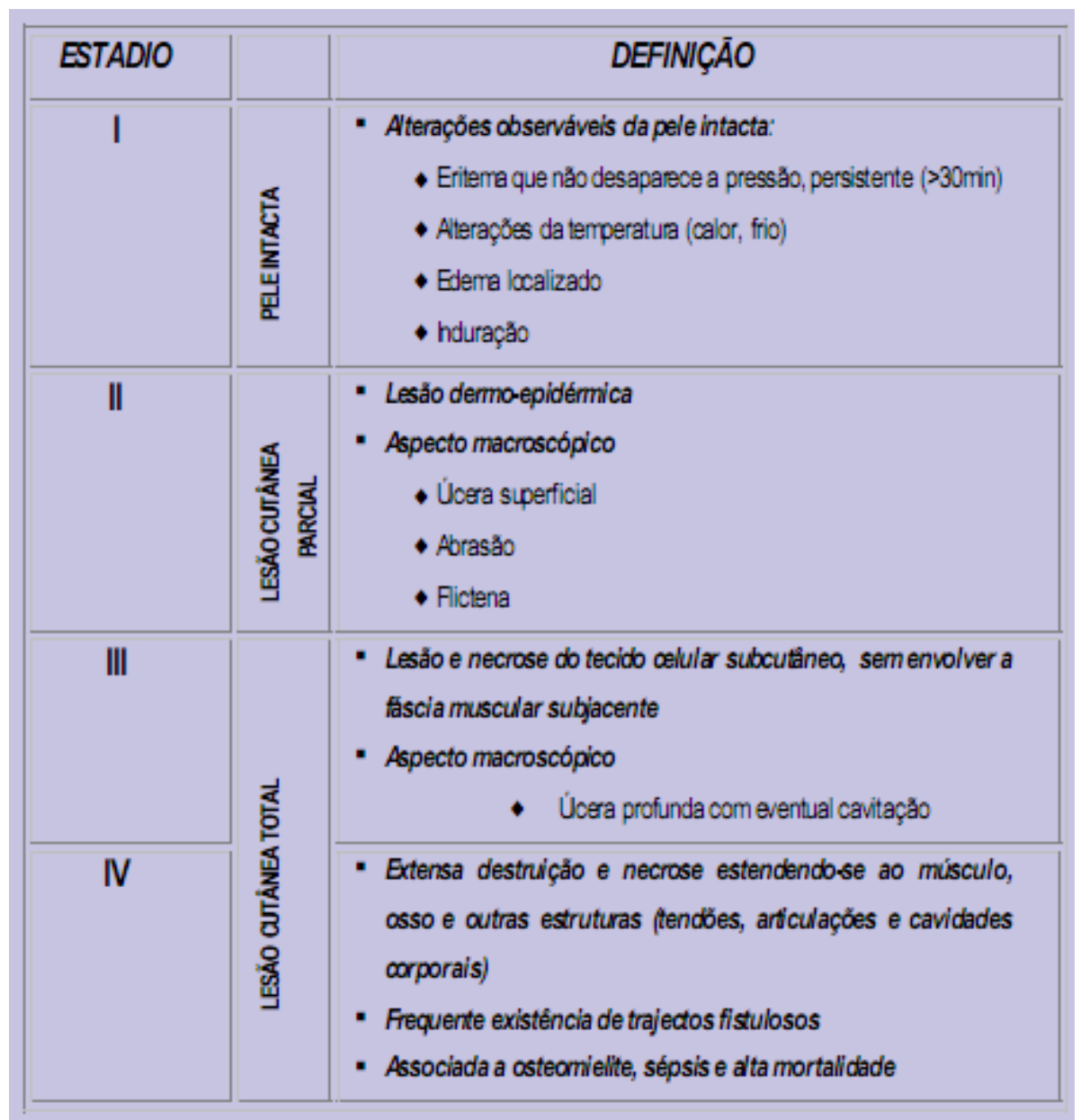

Figura 2: Classificação das úlceras crônicas quanto a sua profundidade (European Pressure Ulcer Advisory Panel, 1999) 
As úlceras de pressão (UP) geralmente se desenvolvem em regiões de proeminências ósseas no corpo como resultado de pressão, má distribuição de peso e/ou fricção. Para pacientes que exigem cuidados em longo prazo, o desenvolvimento da UP é associado a várias condições concomitantes a uma variedade de sintomas. O impacto das UP's e de seus tratamentos é físico, emocional, social e financeiro, e dentre essas, a dor, a restrição das atividades, as mudanças na imagem corporal e a perda da independência/controle são mais profundas (THEIN et al., 2010). As localizações mais frequentemente relatadas são: isquiática (24\%), sacrococcígea (23\%), trocantérica (15\%), e calcânea $8(\%)$. Outras localizações incluem maléolos laterais (7\%), cotovelos (3\%), região occipital (1\%), e região escapular (ROCHA; MIRANDA; ANDRADE, 2006). Estes autores também descrevem fatores de risco extrínsecos e intrínsecos no desenvolvimento das UP's:

- Fatores extrínsecos: pressão (que exceda a pressão de perfusão tecidual, entre 25 e 32 mmHg; tempo prolongado de pressão); fricção (atrito entre o corpo e a superfície; transferências mal executadas); maceração/humidade excessiva.

- Fatores intrínsecos: imobilidade (lesões medulares, encefálicas; pósoperatório de cirurgias ortopédicas, cardiotorácicas); alterações da sensibilidade (lesões neurológicas); incontinência urinária ou fecal; alterações do estado de consciência; idade (> 65 anos); má perfusão/oxigenação tecidual (doenças vasculares, anemia, doença pulmonar obstrutiva crônica, uso de vasopressores, tabagismo, diabetes mellitus, nefropatia, septicemia) e estado nutricional (desnutrição).

A úlcera neurotrófica é advinda da lesão nervosa e determina alterações sensitivas e motoras que levam à instalação de graus variados de incapacidade física. Dentre as incapacidades graves e socialmente relevantes, estão as úlceras cutâneas. A região plantar é abordada como o local comumente acometido por úlceras, devido a alterações biomecânicas e diminuição da sensibilidade dos pés. As úlceras cutâneas constituem uma importante complicação decorrente da neuropatia nos pacientes diabéticos (pé diabético). Essas lesões devem ser abordadas e devidamente prevenidas, pois constituem porta de entrada para infecções que podem se agravar e conduzir o paciente a complicações graves e até mesmo à amputação (GOMES; FRADE; FOSS, 2007). 


\subsection{MEMBRANA DE CELULOSE BACTERIANA (CB)}

A celulose é um polímero formado por repetidas moléculas de $\beta$-D-glicopiranose unidas em cadeias longas, não ramificadas, por ligações glicosídicas $\beta(1 \rightarrow 4)$ (MENEZES, 1997) (Figura 3).

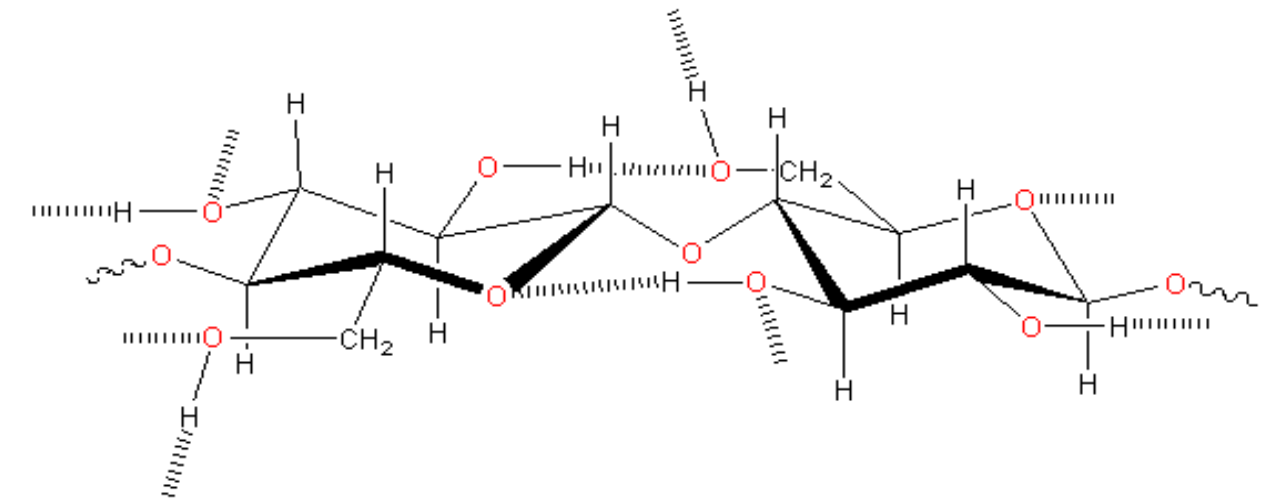

Figura 3: Estrutura linear da celulose. As linhas pontilhadas esquematizam as possíveis ligações de hidrogênio (DONINI et al, 2010)

Este polímero pode ser dividido em duas formas nativas: celulose pura, obtida diretamente de seu estado natural, por exemplo, algodão, celulose bacteriana, e, a celulose produzida por algumas algas; e a celulose complexa, que inclui a maior parte da celulose presente na natureza, componente fundamental da parede celular de plantas superiores, que contêm impurezas como lignina, pectina e hemicelulose (ATALLA, 1999).

A Gluconacetobacter xylinus (Acetobacter xylinum) é uma bactéria aeróbica, gram-negativa, não-patogênica, que possui a capacidade de produzir celulose e foi descrita a primeira vez por Brown em 1886 (KLEMM et al., 2001; 2005). Microrganismos do gênero Acetobacter são facilmente encontrados em frutas, vegetais, vinagre, sucos de frutas e bebidas alcoólicas (ATALLA, 1999).

A G. xylinus secreta celulose como camada de exopolissacarídeos, sendo esta celulose extracelular em forma de fitas compostas de microfibrilas flutuantes organizadas de forma linear ao longo do eixo axial da bactéria, cuja organização forma uma estrutura em 3D constituída por nanofibras (BROWN; WILLISON; RICHARDSON, 1976) (Figura 4). Dentre as propriedades físicas, mecânicas e biológicas existentes na celulose bacteriana, Czaja et al. (2006; 2007b) descrevem que esta promove uma barreira física contra infecção bacteriana, é facilmente 
esterilizável, possui baixo custo, manipulação simples, pode diminuir significativamente a dor durante determinados tratamentos, não é tóxica, é biocompatível, tem alta conformidade e elasticidade, além de alta resistência.

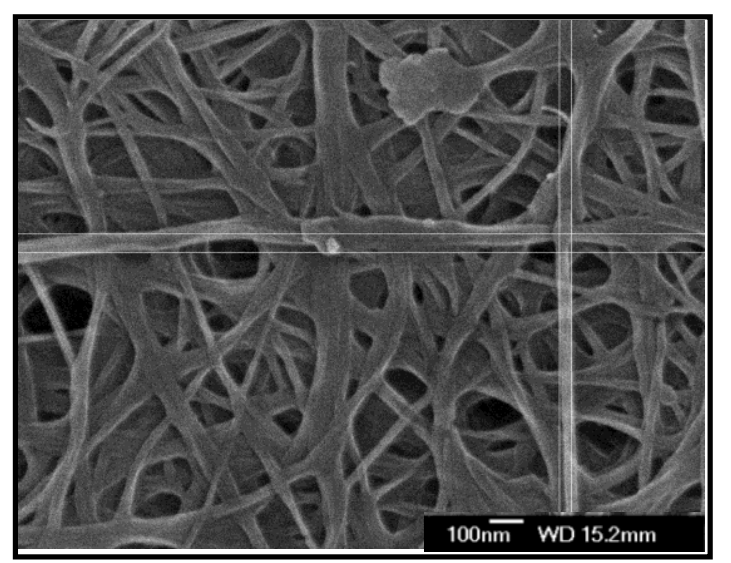

Figura 4: Microscopia eletrônica de varredura (MEV) da organização microfibrilar da celulose sintetizada pela Gluconacetobacter xylinus

Em contraste com outros tipos de membrana sintética, a membrana de CB exibe uma alta resistência à corrosão química, é biodegradável, biocompatível, porosa e ainda possui boa resistência mecânica. Propriedades únicas que a fazem ser um biopolímero com grande potencial a ser explorado pela biotecnologia e outras áreas da ciência biomédica (GEYER et al., 1994).

Há diversos estudos de biocompatibilidade in vivo utilizando a celulose bacteriana; Kolodziejczyk e Pomorski (1999) implantaram celulose bacteriana no subcutâneo de coelhos e avaliaram no período de 1 a 3 semanas. Os implantes não provocaram nenhuma reação inflamatória macroscópica e histologicamente observaram apenas algumas células gigantes e fibroblastos na interface entre a celulose e o tecido. Resultados positivos também foram observados por Klemm et al. (2005) que implantaram um produto a base de celulose bacteriana com formato de tubo para interposição do segmento da artéria carótida de ratos e concluíram que este procedimento pode ser realizado não apenas para a reestruturação de vasos sanguíneos, como também traqueia, ou trato gastrintestinal.

Helenius et al. (2006) implantaram celulose bacteriana no dorso de ratos e após os períodos de 1, 4 e 12 semanas não observaram nenhum processo inflamatório, macroscópico ou mesmo histológico, sem a presença de células gigantes e observaram um quadro de angiogênese - formação de novos vasos sanguíneos - ao redor e no interior dos implantes. 
Segundo Ono, Watanabe, Yamanaka (1989) a celulose bacteriana pode ser considerada uma substituta da parede abdominal, pele, tecido subcutâneo, tecido cartilaginoso e até mesmo reforço para áreas de baixa resistência das paredes abdominais, esôfago e tudo intestinal. Este fato também foi descrito por Falcão, Neto e Coelho (2008), que realizaram uma experiência com celulose bacteriana e politetrafluoetileno (PTFE), inserindo estes dois biomateriais nas paredes abdominais de ratos, e concluíram que a celulose trata-se de uma barreira mecânica que impede à infiltração de líquidos corporais no local dos implantes o que aumenta a resistência a tração na interface implante/tecido íntegro, fato este que não pode ser observado com o PTFE.

Cabral et al. (2003) realizaram duas lesões de formato circular "punch", com superfície de corte de dois centímetros de diâmetro; localizadas na linha média da região dorsal de ratos, onde uma foi recoberta com a película de celulose e a outra, não foi recoberta. Esta forma de modelo experimental possibilitou estudos quanto ao aspecto macroscópico das lesões (contratura e fechamento das úlceras), bem como a análise de parâmetros morfométricos e morfológicos e concluíram que as úlceras cicatrizaram de maneira mais rápida e uniforme quando recobertas pela celulose.

A celulose bacteriana não somente foi utilizada como um material promissor para a cicatrização do subcutâneo de animais, mas em um estudo desenvolvido por Oliveira et al. (2007), verificou-se que a utilização da película de celulose biossintética parece ser mais adequada como substituto de dura-máter para cobertura e proteção do tecido nervoso do que a matriz dérmica humana acelular. Ela parece promissora na correção intra-uterina da mielomeningocele, evitando a aderência do tecido nervoso aos planos superficiais, minimizando os efeitos deletérios do ambiente intra-uterino sobre a medula espinhal.

\subsection{PRÓPOLIS}

A própolis é um complexo resinoso formado pela mistura de substâncias retiradas de botões de flores, de árvores ou de cascas de árvores com substâncias do próprio organismo da abelha (FRANCO et al., 2000). Segundo Woisky e Salatino (1998), sua composição química varia de acordo com o local da coleta e com a vegetação nativa no qual o apiário está instalado. Essa diversidade na composição química inclui flavonoides (como a galangina, quercetina, pinocembrina e 
kaempferol), ácidos aromáticos e ésteres, aldeídos e cetonas, terpenoides e fenilpropanoides (como os ácidos caféico e clorogênico), esteroides, aminoácidos, polissacarídeos, hidrocarbonetos, ácidos graxos e vários outros compostos em pequenas quantidades (ROCHA et al., 2003).

A partir do experimento de Russo, Longo e Vanella. (2002) sobre os componentes químicos encontrados na própolis pode se dizer que com a presença de éster fenetil de ácido caféico há uma potencialização da capacidade antioxidante do composto, fazendo com que neutralizem a ação de formas reativas do oxigênio (radicais livres). É importante salientar que a ausência desse componente apenas reduz a capacidade de antioxidante da própolis, mas não a retira.

Estudos demonstraram que a própolis possui efeitos antibacteriano (THIRUGNANASAMPANDAN; RAVEENDRAN; JAYAKUMAR, 2012) antifúngico, antiviral, anti-inflamatório, hepatoprotetor, antioxidante, antitumoral e imunomodulatórios. Dentre estas propriedades funcionais, a sua atividade antibacteriana tem sido vinculada, principalmente, aos flavonoides. Componentes fenois, terpeno, ácidos aromáticos e ésteres também exercem atividade antibacteriana (KAYAOGLU et al., 2011).

Santos et al. (2002) relataram que bactérias como Peptostreptococcus anaerobius, Porphyromonas gingivalis e Prevotella intermedia, observadas em doenças periodontais são sensíveis a própolis; esse efeito bactericida também foi demonstrado com outras espécies de bactérias Gram-positivas: Staphylococcus aureus, Enterococcus spp., Corynebacterium spp., Bacillus cereus e Bacillus subtilis; Gram-negativas: Escherichia coli, Klebsiella pneumoniae e Pseudomonas aeruginosa e também Mycobacterium tuberculosis por Grange e Darvey (1990); Bonvehi, Coll e Jorda (1994), e Menezes et al. (1997). Além disso, a inibição dos principais agentes causadores da cárie dental o Streptococcus mutans, Streptococcus sobrinus e Streptococcus cricetus pela própolis, foi observada por Ikeno, Ikeno e Miyazawa (1991). As bactérias normalmente encontradas em úlceras crônicas cutâneas são da microbiota normal da pele, que inclui principalmente os Cocos Gram-positivos aeróbios e eventualmente os anaeróbios; e os patógenos mais frequentemente isolados em infecções dessas úlceras de pele são os estreptococos, seguidos dos estafilococos e peptoestreptococos (SADER; DURAZZO, 2003). 
Estudos realizados por Eraslan, Kanbur e Silici (2007) e Newairy et al. (2009) verificaram capacidade antioxidativa da própolis. Bevilacqua et al. (1997) confirmaram o efeito antimicrobiano da própolis e segundo Cizmarik e Matel, (1970, 1973); Metzner et al. (1979); Schneidewind et al. (1979); Vanhaelen, VanhaelenFastrè (1979); Bankova, Popov e Marekov (1988); Kedzia (1990); Guarini et al. (1992) afirmam que este efeito pode ser mais efetivo se houver a mistura do própolis com algum outro agente anti-inflamatório, o que provavelmente provocaria uma ação sinérgica.

Até o momento não há relatos na literatura de aplicação de curativos a base de própolis no tratamento de úlceras crônicas em seres humanos, tornando o presente estudo pioneiro nesse tipo de aplicação.

\subsection{LASER DE BAIXA INTENSIDADE}

A palavra laser é um acrônimo de "Light Amplification by Stimulated Emission of Radiation", ou seja, "Luz Amplificada por Emissão Estimulada de Radiação". O princípio da emissão estimulada foi proposto primeiramente, sob forma teórica, por Einstein, em 1917: a emissão estimulada de radiação é causada pela presença de um fóton indutor de energia interagindo com um átomo em seu estado excitado, resultando na liberação de dois fótons induzidos (Gutknecht; Eduardo, 2004).

O laser é um tipo de energia eletromagnética que, dependendo de sua fonte, pode ser convertida em energia luminosa visível ou não. O raio laser é um tipo de radiação não-ionizante, não-invasiva, altamente concentrada, que em contato com diferentes tecidos, promove efeitos térmicos e fotoquímicos alineares (Ribeiro et al., 2009 a,b).

Os primeiros sistemas LLLT (Low-level Laser Therapy), ou LBI (Laser de Baixa Intensidade), tinham como meio ativo uma mistura gasosa de gás hélio e neônio (lasers de HeNe) que emitiam no vermelho $(632,8 \mathrm{~nm})$, mas que apresentavam também outra linha de emissão no verde. Atualmente os sistemas laser LLLT são, na sua grande maioria, constituídos de um cristal confeccionado em laboratório de diodo semicondutor de arseneto de gálio (GaAs) podendo estar dopado por diversos outros elementos, dependendo do comprimento de onda desejado (Gutknetcht; Eduardo, 2004). 
Estudos prévios demonstraram um valor clínico significativo para o uso da LBI na aceleração do processo de cura de úlceras superficiais. Apesar dos mecanismos de aceleração da cura das úlceras não serem conhecidos, estudos recentes tem demonstrado que a luz vermelha visível do LBI acelera o crescimento celular e melhora o metabolismo celular num modo dose-dependente e tempo-dependente (Skopin; Molitor, 2009). Pretel et al. (2002) e Nicolau et al. (2003) demonstraram, após irradiação de úlceras, que o LBI aumentou o grau de vascularização do tecido neoformado.

Com o aumento da produção de ATP, causada pela aplicação da energia do LBI, a velocidade de mitose é aumentada. Esse fato leva a concluir que este laser aumenta os processos de reparação tecidual devido ao estímulo na capacidade de cicatrização do tecido conjuntivo, o que ajuda a reparar perdas de substância das úlceras de diversas origens (GUZARDELLA et al., 2002).

O Laser controla a produção de substâncias liberadas nos fenômenos de dor e inflamação, como as prostaglandinas, prostaciclinas, histamina, serotonina, bradicinina, leucotrienos, etc. Ele atua também nas reações enzimáticas normais como na produção de ATP (CAMPANA et al., 1998). O efeito bioelétrico da radiação laser ajuda a normalizar o potencial da membrana, atuando como reequilibrante e normalizador da atividade funcional da célula, assim como no aumento do $\mathrm{Ca}^{2+}$ intracelular (KARU et al., 1995).

Desta forma, a laserterapia é usada para úlceras de pressão, úlceras diabéticas, úlceras venosas e arteriais, úlceras de enxerto, incisões, lacerações e queimaduras. Estudos in vivo $\mathrm{e}$ in vitro mostraram que o tratamento com laser acelera reações bioquímicas, atividade fibroblástica e metabolismo do colágeno (DEMIR et al., 2004).

Existe uma ampla variação de recomendações da energia ideal para diferentes condições; a intensidade usual é de 0.5 a $10 \mathrm{~J} / \mathrm{cm} 2$. Geralmente, o comprimento de onda do laser mais utilizado em medicina física é entre 630 e 984 nm segundo Demir et al. (2004). Os lasers emitidos na região do visível foram os mais utilizados na terapia de cicatrização de úlceras de acordo com Mester (1985).

Pereira et al. (2012) em seu estudo com tratamento de úlceras de pele em ratos, utilizou o LBI em um comprimento de onda de $670 \mathrm{~nm}$, onde constatou que o laser facilitou a síntese do colágeno, estimulou a proliferação celular e proliferação de outros elementos que constituem a matriz extracelular. Esses autores também 
notaram os efeitos do laser na microcirculação, pois ele também promove a vasodilatação e a angiogênese. 


\section{OBJETIVO}

Este trabalho teve como objetivo avaliar a eficácia da aplicação de curativos temporários de Membrana de Celulose Bacteriana pura ou com própolis associadas ou não a aplicação de Laser de Baixa Intensidade em indivíduos adultos que apresentaram úlceras crônicas de diferentes etiologias através da análise descritiva dos casos. 


\section{CASUÍSTICA E MÉTODOS}

\subsection{OBTENÇÃO DAS MEMBRANAS DE CB PURA E DE CB COM PRÓPOLIS}

As amostras de CB pura foram fornecidas pela empresa Fibrocel Produtos Biotecnológicos LTDA, situada em Ibiporã, Paraná. As membranas de CB com própolis foram obtidas em cooperação com o Laboratório de Materiais Fotônicos do Instituto de Química da UNESP - Campus de Araraquara, sob responsabilidade do Prof. Dr. Sidney José de Lima Ribeiro e colaboração do Pós-doutorando Hernane da Silva Barud.

O cultivo das bactérias Gluconacetobacter xylinus foi realizado em meio de cultura estática (Figura 5) em frascos elenmeyers de $500 \mathrm{~mL}$ com tempo de cultivo de 120 horas a $28^{\circ} \mathrm{C}$ (5 mm de espessura). O meio de cultura foi composto de glicose $2 \%(\mathrm{~m} / \mathrm{v})$, peptona $0,5 \%(\mathrm{~m} / \mathrm{v})$, extrato de levedura $0,5 \%$, fosfato dissódico anidro $0,27 \%(\mathrm{~m} / \mathrm{v})$ e ácido cítrico monohidratado $0,115 \%(\mathrm{~m} / \mathrm{v})$. Após 72 horas obtêve-se mantas de CB altamente hidratadas com espessura média de $4 \mathrm{~mm}$.

A celulose foi obtida em forma de uma membrana gelatinosa formada na interface meio de cultura/superfície (Figuras 6 e 7). Para remover as bactérias, a membrana passou por tratamento químico com solução de hidróxido de sódio $2 \%$ a $80^{\circ} \mathrm{C}$ por $1 \mathrm{~h}$ e em seguida utilizou-se solução de hipoclorito de sódio $1 \%$ por $30 \mathrm{~min}$, sendo posteriormente lavada exaustivamente com água destilada até neutralização do $\mathrm{pH}$ e acondicionada em água deionizada. Após várias trocas de água deionizada as membranas foram autoclavadas por 15 minutos a $120^{\circ} \mathrm{C}$. Para obtenção das membranas $\mathrm{CB}$ secas puras, as amostras foram levadas a uma estufa a $37^{\circ} \mathrm{C}$ por cerca de 8 horas em molde prensado (Figura 8). 


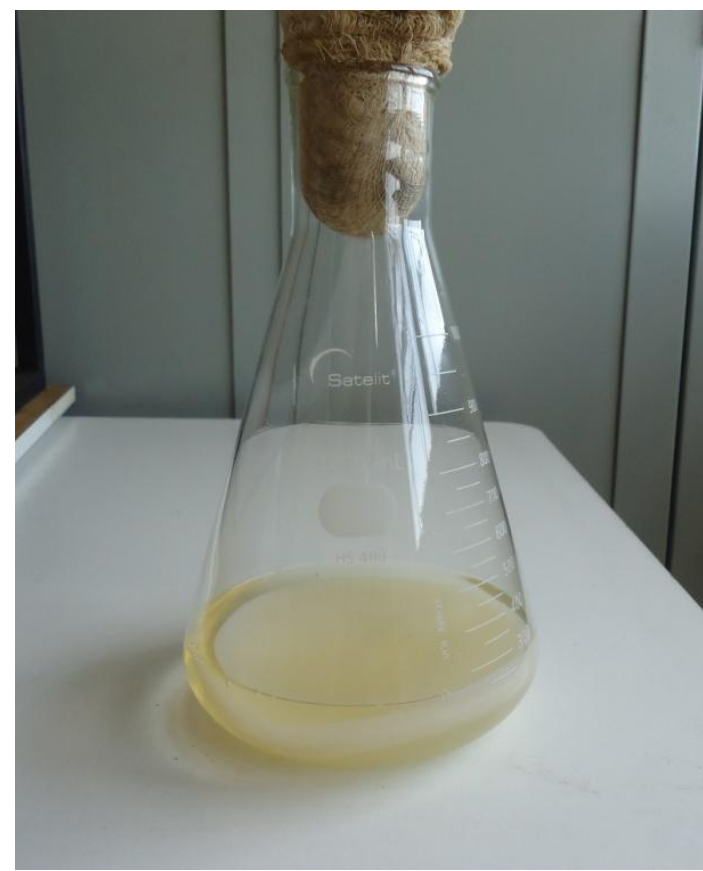

Figura 5: Demonstração de uma cultura da Gluconacetobacter xylinus

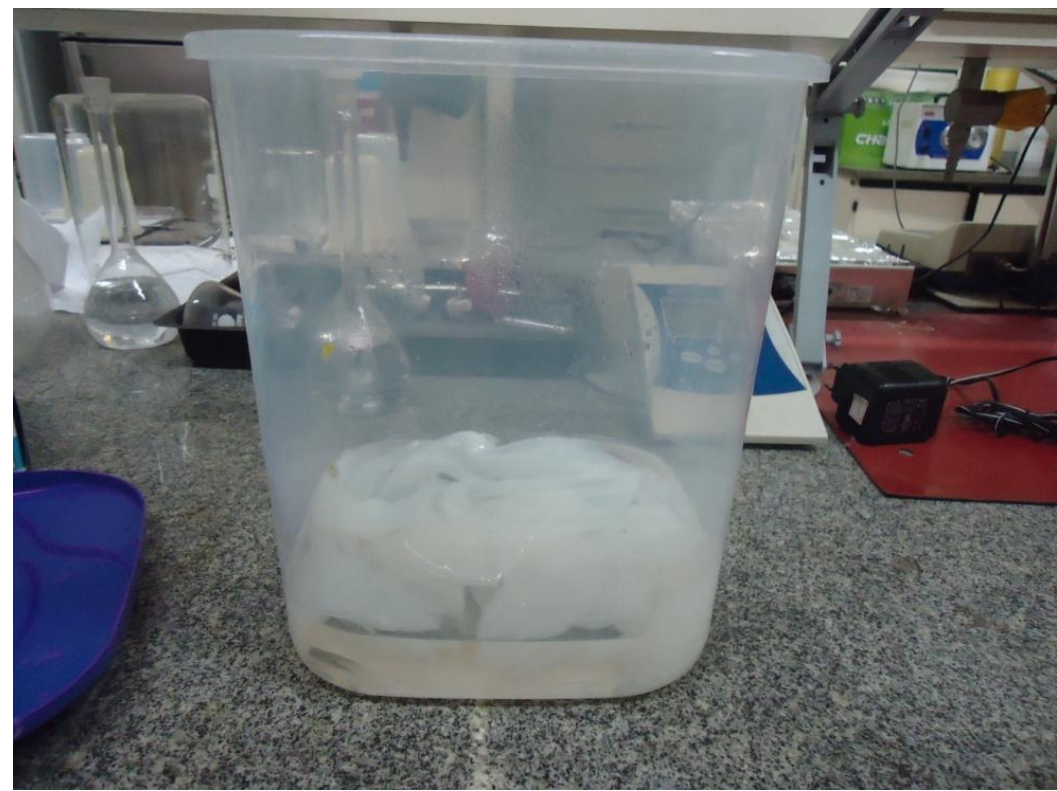

Figura 6: CB hidratada 


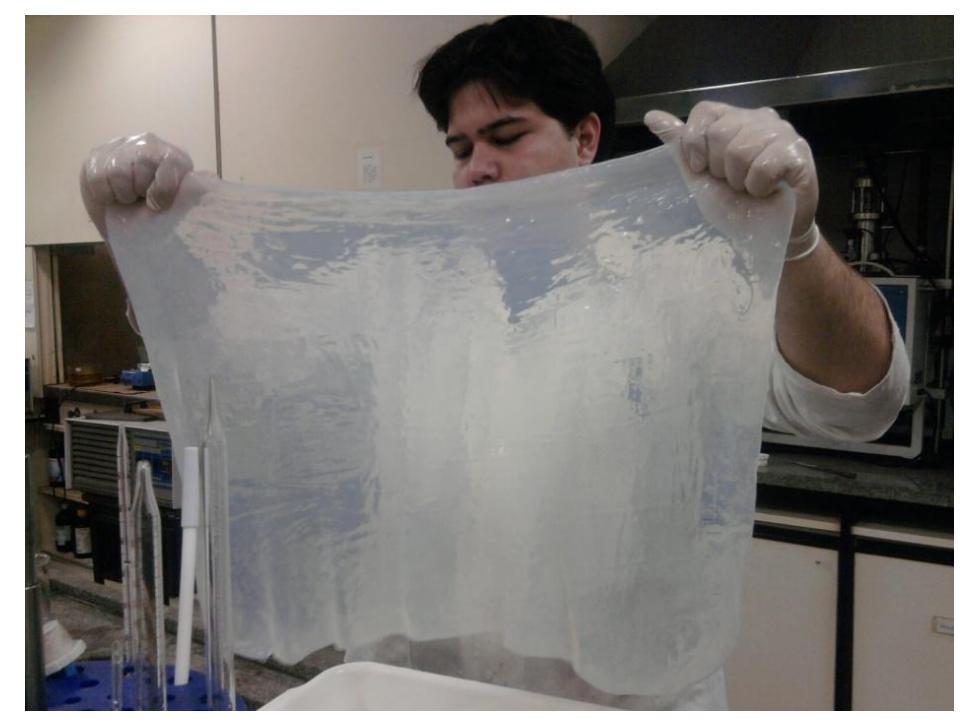

Figura 7: Manta de CB úmida após purificação

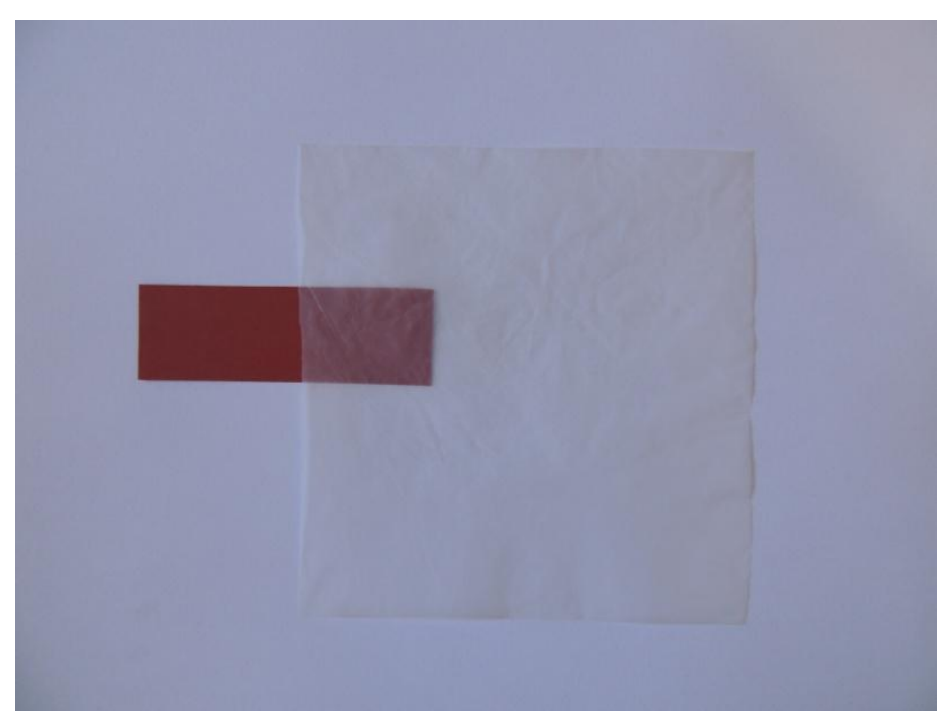

Figura 8: Membrana de CB pura seca (demonstração de sua transparência)

Para a produção das membranas com própolis, utilizou-se 0 extrato padronizado de própolis (EPP) a 10\% (enviado pela empresa Apis Flora, de Ribeirão Preto). Foram preparadas as soluções alcoólicas com própolis a 2,4\%, medindo-se $24 \mathrm{ml}$ de EPP e completando o volume para $100 \mathrm{ml}$ com álcool etílico. As mantas úmidas de membrana de CB foram imersas nessa solução de EPP a 2,4\% (Figura 9) por 24 horas e depois passaram por processo de secagem em estufa a $37^{\circ} \mathrm{C}$ por cerca de 4-5 horas com auxílio do molde para evitar enrugamento (Figura 10). 


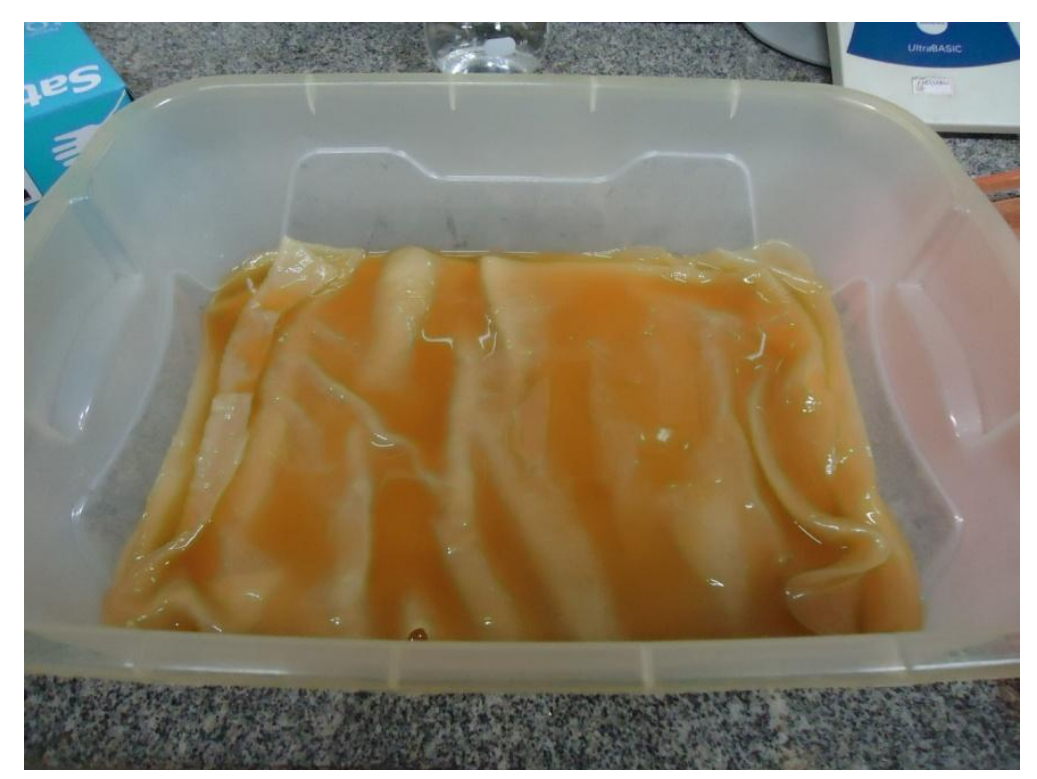

Figura 9: Membrana de CB úmida imersa em solução de EPP a 2,4\%

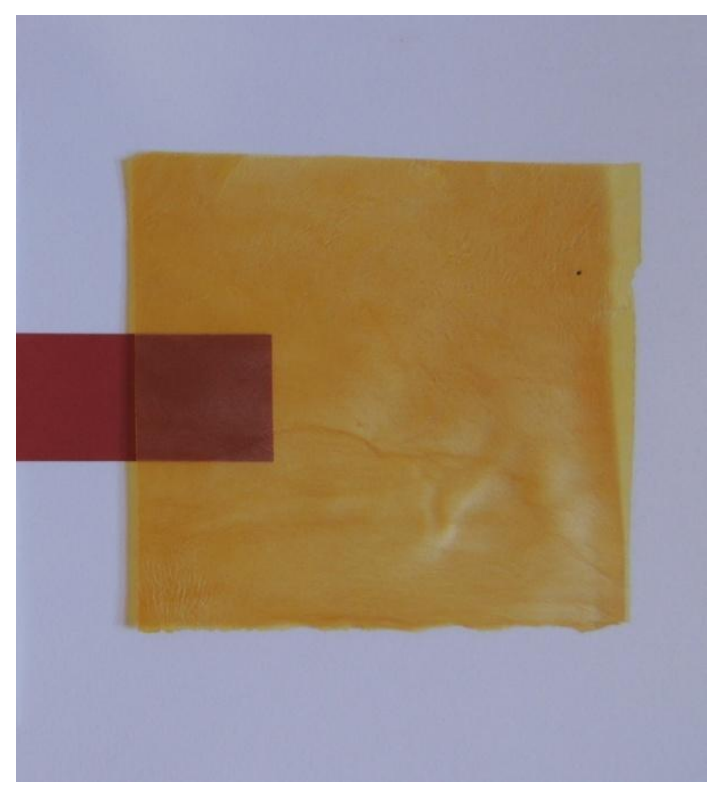

Figura 10: Membrana com própolis seca (demonstração de sua transparência)

A Figura 11 demonstra um comparativo entre a coloração e transparência entre as duas membranas de $\mathrm{CB}$, com própolis e pura. 


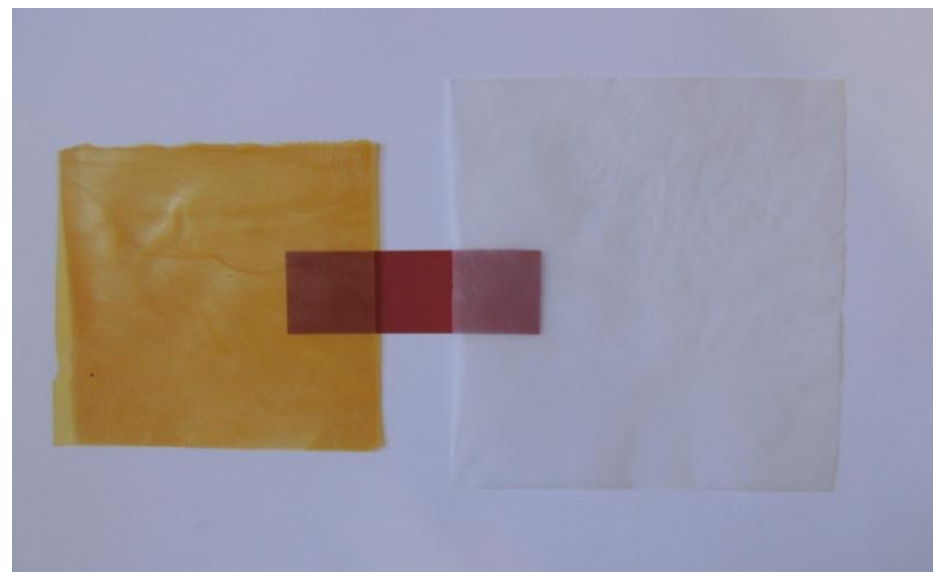

Figura 11: Comparação entre membrana de CB pura e com própolis

Depois de secas, todas as membranas foram esterilizadas com radiação gama 20 kGy, pela empresa Embrarad (Cotia - SP).

\subsection{ESPECIFICAÇÕES DO LASER DE BAIXA INTENSIDADE}

A unidade de LBI utilizada para essa pesquisa foi o Flash Lase I, com as seguintes especificações: meio ativo Índio Gálio Alumínio Fósforo (InGaAIP), vermelho visível, comprimento de onda de $660 \mathrm{~nm}$, potência de emissão de 100 $\mathrm{mW}$, fibra óptica de emissão de $1 \mathrm{~mm}$ de diâmetro, condutor fibra óptica de sílica. Esse aparelho (Figura 12) foi fornecido pelo Núcleo de Pesquisa e Ensino em Fototerapia - DMC de São Carlos, através do Dr. Hermes Pretel.

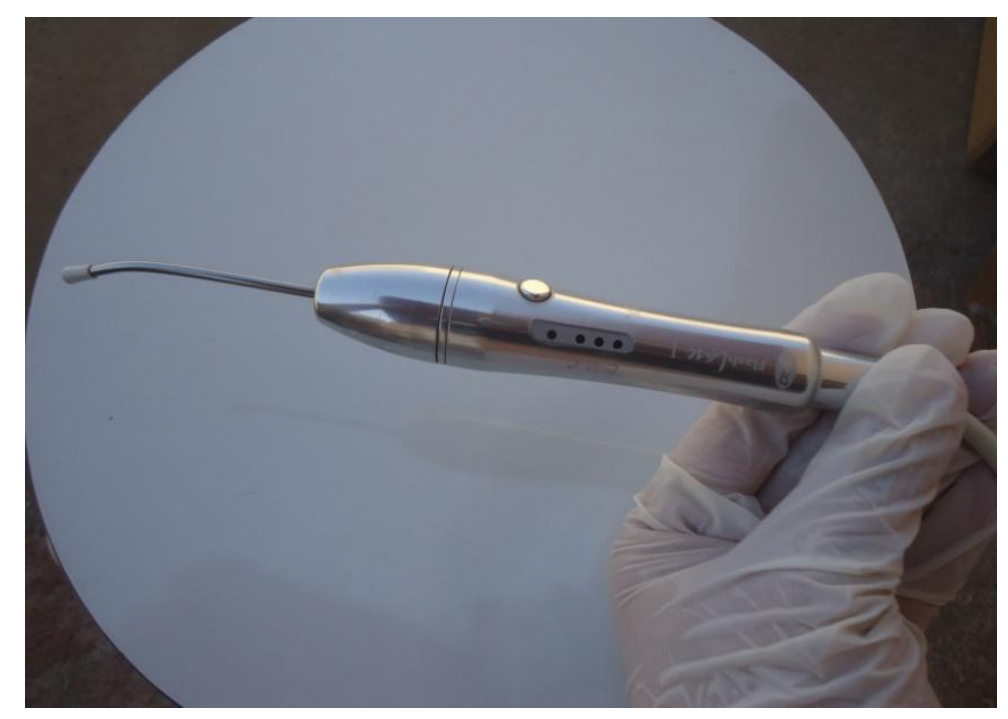

Figura 12: Aparelho Flash Lase I 


\subsection{EXPERIMENTAÇÃO}

Este estudo foi randômico e sua amostra experimental constituiu de 8 pacientes e 12 úlceras crônicas, que foram divididos em 5 grupos de tratamento: Grupo Membrana de CB Pura (G1), Grupo Membrana de CB /Própolis (G2), Grupo Laser (G3), Grupo Membrana de CB Pura + Laser (G4), Grupo Membrana de CB /Própolis + Laser (G5) (Tabela 1). O G1 e G3 foram considerados os grupos controle-positivos. Os pacientes foram divididos nos grupos aleatoriamente e assinaram um Termo de Consentimento Pré-informado antes de participar da pesquisa (Apêndice A). Este projeto foi submetido e aprovado pelo Comitê de Ética em Pesquisa (CEP - UNIARA, nº de protocolo 1096/10; Anexo A).

Tabela 1 - Divisão dos grupos de tratamento e procedimentos

\begin{tabular}{ccc}
\hline Grupos & “N” & Procedimento \\
\hline G1 & 2 & Membrana CB pura \\
G2 & 3 & Membrana CB/Própolis \\
G3 & 2 & Laser \\
G4 & 3 & Membrana CB pura + Laser \\
G5 & 2 & Membrana CB/Própolis + Laser \\
\hline
\end{tabular}

Os pacientes que foram submetidos à aplicação de curativos de CB Pura e associada à Própolis (grupos G1, G2, G4 e G5) tiveram seus curativos acompanhados semanalmente, e a membrana foi trocada quando houve excesso de exsudato inflamatório que não permitia a aderência ideal do curativo.

O curativo foi realizado dessa forma:

- Lavagem da úlcera com água com temperatura em torno de $37^{\circ} \mathrm{C}$;

- Limpeza da úlcera com Clorexidina 2\%;

- Enxágue com soro fisiológico (SF) com temperatura em torno de 37ํㅜ;

- Secagem da úlcera com gaze estéril;

- Colocação da membrana na úlcera (1 cm maior do que a margem da úlcera) (Figura 13); 
- Leve compressão sobre a membrana com auxílio de gaze embebida em SF para aderir no leito da úlcera;

- Proteção da membrana com gaze estéril e enfaixamento do local.

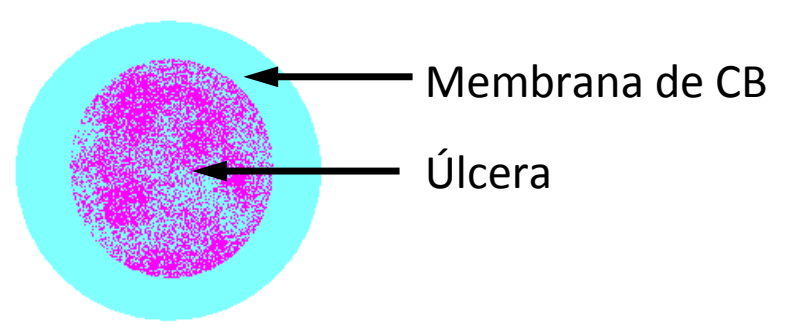

Figura 13: Figura demonstrativa da colocação da membrana sobre a úlcera

Todo o material que foi utilizado no curativo foi descartável (luvas, gaze, algodão, faixas). O acompanhamento foi realizado até o momento da cura da úlcera ou até o período máximo de 90 dias.

Nos pacientes pertencentes aos grupos irradiados (G3, G4 e G5), a aplicação do laser nas úlceras foi realizada pontualmente com espaçamento de $1 \mathrm{~cm}$ entre os pontos de aplicação, com tempo de irradiação de 10 segundos (1 Joule), nas margens e no interior da úlcera (Figura 14). O período de intervalo entre as sessões foi de cerca de 72 horas. As aplicações foram realizadas até o momento da cura da úlcera ou até o período máximo de 90 dias.

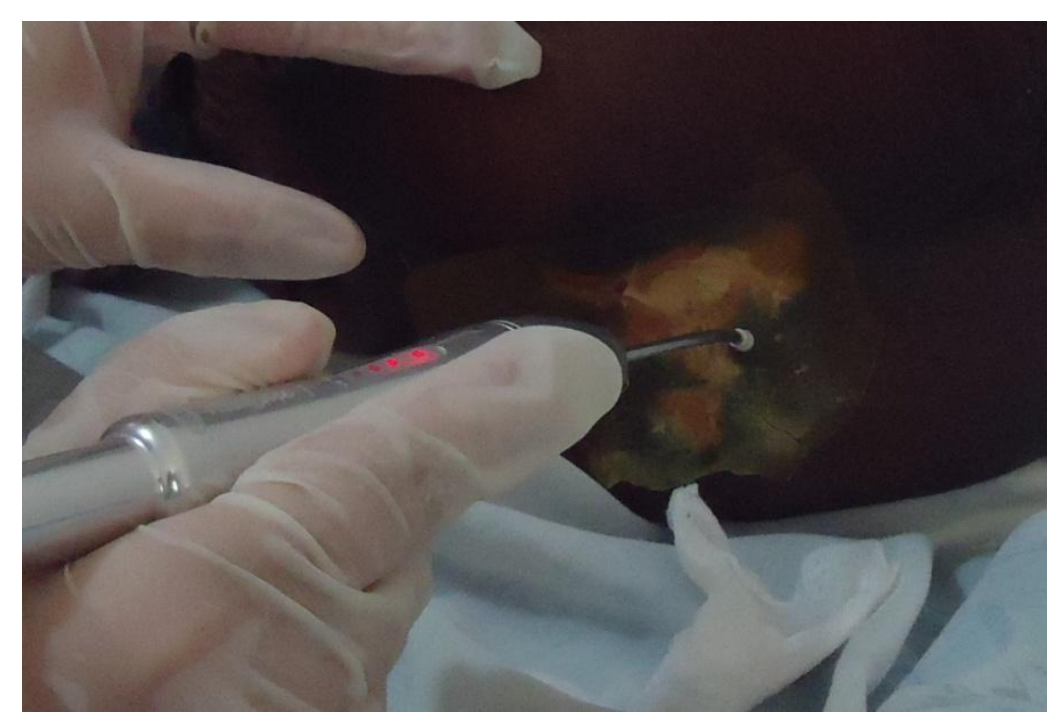

Figura 14: Demonstração da aplicação do LBI 


\subsection{TESTE DE ABSORBÂNCIA DO LASER}

Para melhor quantificação da porcentagem de absorção do raio laser pela membrana de CB pura e com própolis durante as sessões, foi realizado um Teste de Absorbância do Laser em colaboração com o Laboratório de Materiais Fotônicos do Instituto de Química - UNESP de Araraquara com auxílio do Pós-doutorando Danilo Manzani.

Para este teste, foi utilizado o potenciômetro da Newport Power Meter, modelo 2935-C (Figura 15). O potenciômetro contém um fotodetector modelo 918D UV-OD3 Newport, placa de silício, de $1 \mathrm{~cm}^{2}$ de área de detecção, range de 200 à $110 \mathrm{~nm}$ e um Atenuador Newport OD (utilizado para trabalhar com altas potências, até $200 \mathrm{~mW}$ ).

O potenciômetro foi utilizado no modo contínuo de análise (Figura 16), fixado em $670 \mathrm{~nm}$ (próximo ao comprimento de onda do laser utilizado nesta pesquisa, que foi de $660 \mathrm{~nm})$. Foram realizadas 3 medições da potência total $(\mathrm{mW})$ somente com o raio laser, 3 medições com o raio laser através da membrana de CB pura e 3 medições com raio laser através da membrana de CB com própolis, e depois tirada a média; o posicionamento da caneta de laser foi exatamente na região central do fotodetector (Figura 17). Para fixação das membranas, foi utilizado papel filme (transparente), que também é usado durante as aplicações do laser nas úlceras para evitar contaminação. A análise foi feita a partir do disparo do laser por 10 segundos, com $1 \mathrm{~J}$ de intensidade, de acordo com o protocolo de tratamento. A Tabela 2 demonstra os valores do teste:

Tabela 2 - Dados do teste de absorbância do laser através das membranas de CB pura e com própolis

\begin{tabular}{lcccccc}
\hline & Teste 1 & Teste 2 & Teste 3 & Média & $\begin{array}{c}\text { \% raio que } \\
\text { ultrapassa }\end{array}$ \\
& & & & & \\
\hline Laser & $107 \mathrm{~mW}$ & $103 \mathrm{~mW}$ & $100 \mathrm{~mW}$ & $103 \mathrm{~mW}$ & \\
\hline Laser através da CB pura & $90 \mathrm{~mW}$ & $89 \mathrm{~mW}$ & $89 \mathrm{~mW}$ & $89 \mathrm{~mW}$ & $86,4 \%$ \\
\hline Laser através da CB própolis & $57 \mathrm{~mW}$ & $54 \mathrm{~mW}$ & $53 \mathrm{~mW}$ & $54 \mathrm{~mW}$ & $52,4 \%$ \\
\hline
\end{tabular}




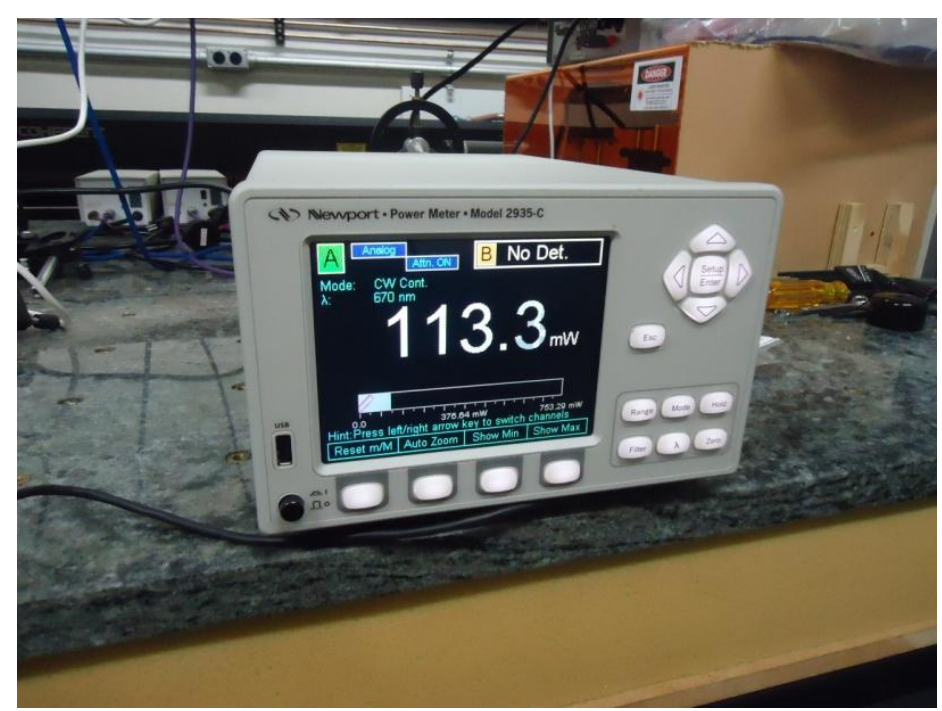

Figura 15: Visor do potenciômetro durante a análise

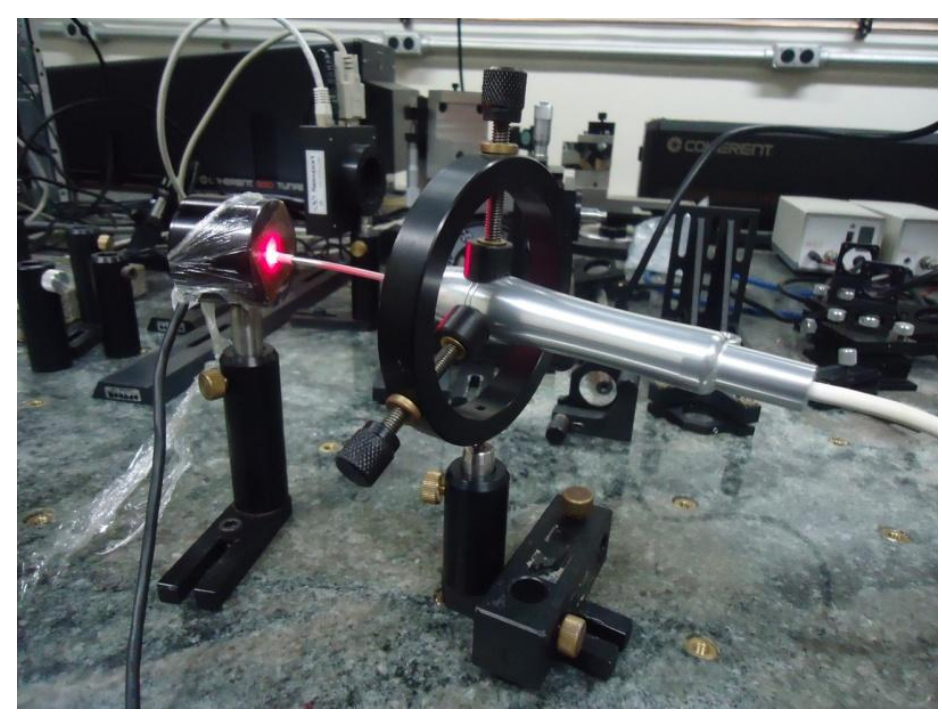

Figura 16: Demonstração da análise da membrana de CB (própolis)

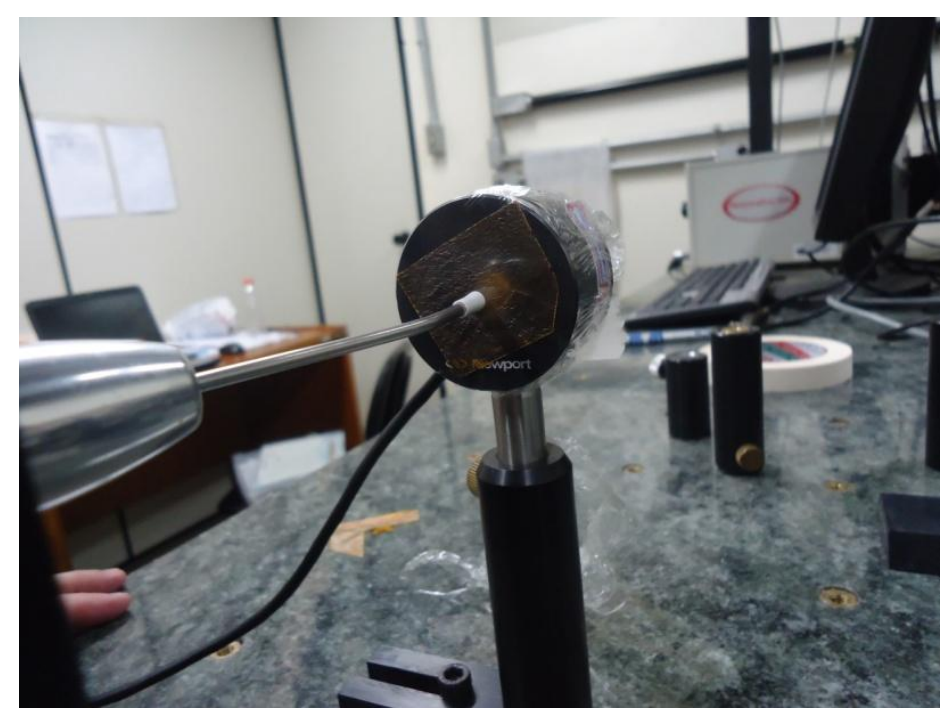

Figura 17: Posicionamento da caneta do laser na região central do fotodetector 


\subsection{AVALIAÇÃO DAS ÚLCERAS}

As úlceras foram avaliadas antes, durante (semanalmente) e após a aplicação das membranas e do laser. A partir de fotografias com câmera digital (Sony Cybershot 14.1 mega pixels), as úlceras tiveram sua área total analisada através do software ImageJ 1.46, disponível gratuitamente na rede e desenvolvido por Wayne Rasband do Research Services Branch, National Institutes of Health - NIH (Bethesda, Maryland, EUA).

Inicialmente, em <Set Measurements $>$ do menu <Analyze> o ImageJ foi programado para calcular áreas de imagens habilitando a caixa "Area". A imagem foi aberta pressionando em <Open> no menu <File> e em seguida, foi feito a calibração do ImageJ baseando-se em distância conhecida. Utilizando a ferramenta "Straight" do ImageJ, foi traçado na régua (na direção da úlcera) o limite correspondente à $5 \mathrm{~cm}$. Em <Set Scale> do menu <Analyze> apareceu na caixa "Distance in pixels" o valor em pixels correspondente ao traço feito previamente sobre a régua. Foi digitado então na caixa "Know distance" o número "5" e digitado "cm" na caixa "Unit of lenght". A caixa "Global" deveria ficar sempre habilitada. Abaixo apareceu o valor da relação entre a distância conhecida e desconhecida em pixels $/ \mathrm{cm}$. O software foi individualmente calibrado em cada imagem analisada. Utilizando a ferramenta "Freehand selections" foi traçado o contorno do leito da úlcera desconsiderando as áreas já reepitelizadas. Por fim, pressionando em <Measure $>$ do menu <Analyze> obteve-se o valor da área traçada em $\mathrm{cm}^{2}$ tendo como base a calibração realizada em $<$ Set Scale $>$.

Após calculadas as áreas de cada úlcera pelo software ImageJ, foi feito o cálculo do índice de cicatrização das úlceras (ICU) pela seguinte fórmula:

$$
\mathrm{ICU}=\frac{\text { Área inicial }- \text { Área final }}{\text { Área inicial }}
$$

Valores de ICU maiores que zero e menores que 1 representam diminuição da área ulcerada (reepitelização parcial), valores menores que zero representam aumento da área ulcerada e valores iguais a 1 representam reepitelização total segundo Caetano et al. (2009) e Minatel et al. (2009). A área 
inicial corresponde ao primeiro dia de tratamento e a área final corresponde ao último dia de tratamento ou dia da cura total.

\subsubsection{Análise descritiva}

A análise realizada neste estudo foi descritiva, com elaboração de uma Tabela para facilitar o entendimento dos protocolos de tratamento e seus resultados em forma de dados numéricos. 


\section{RESULTADOS E DISCUSSÃO}

A partir dos dados expostos na Tabela 3, serão descritos a seguir os casos clínicos dentro de seus respectivos grupos. As fotografias demonstradas se referem aproximadamente aos períodos: inicial, pós 7 dias, pós 15 dias, pós 30 dias, pós 60 dias e pós 90 dias, segundo cada caso. Essa padronização de datas aproximadas na demonstração das fotografias foi feita para tornar mais clara a análise dos dados.

Tabela 3 - Demonstração dos resultados da experimentação. $\left({ }^{*}\right)$ Aumento da área ulcerada

\begin{tabular}{|c|c|c|c|c|c|c|c|}
\hline **Grupo & Úlcera & $\begin{array}{l}\text { Tipo e Tempo } \\
\text { existente }\end{array}$ & $\begin{array}{l}\text { Tempo de } \\
\text { tratamento }\end{array}$ & $\begin{array}{l}\text { Área } \\
\text { inicial } \\
\left(\mathrm{cm}^{2}\right)\end{array}$ & $\begin{array}{l}\text { Área } \\
\text { final } \\
\left(\mathbf{c m}^{2}\right)\end{array}$ & ${ }^{* \star \star} I \mathrm{CU}$ & $\begin{array}{c}\% \\
\text { redução }\end{array}$ \\
\hline \multirow[t]{2}{*}{ G1 } & G1 a & venosa/4 anos & 27 dias & 7,199 & 1,171 & 0,84 & $83,8 \%$ \\
\hline & G1 b & cirúrgica/1 ano & 24 dias & 0,732 & 0 & 1 & $100 \%$ \\
\hline \multirow[t]{3}{*}{ G2 } & G2 a & pressão/1 mês & 9 dias & 0,932 & 0 & 1 & $100 \%$ \\
\hline & G2 b & traumática/1 mês & 10 dias & 1,341 & 0 & 1 & $100 \%$ \\
\hline & G2 c & traumática/7 dias & 14 dias & 0,863 & 0 & 1 & $100 \%$ \\
\hline \multirow[t]{2}{*}{ G3 } & G3 a & pressão/1 ano & 87 dias & 4,948 & 0,169 & 0,97 & $96,5 \%$ \\
\hline & G3 b & cirúrgica/1 ano & 24 dias & 0,479 & 0 & 1 & $100 \%$ \\
\hline \multirow[t]{3}{*}{ G4 } & G4 a & arterial/2 anos & 43 dias & 12,381 & 0 & 1 & $100 \%$ \\
\hline & G4 b & pressão/3 meses & 85 dias & 1,091 & 0 & 1 & $100 \%$ \\
\hline & G4 c & pressão/6 meses & 87 dias & 4,260 & 2,2 & 0,48 & $48,3 \%$ \\
\hline \multirow[t]{2}{*}{ G5 } & G5 a & pressão/6 meses & 85 dias & 2,068 & 0 & 1 & $100 \%$ \\
\hline & G5b & diabética/5 anos & 75 dias & 2,01 & 4,034 & -1 & *200,7\% \\
\hline
\end{tabular}

\begin{tabular}{|l|}
\hline G1 > Grupo membrana de CB pura \\
\hline G2 > Grupo membrana de CB com própolis \\
\hline G3 > Laser \\
\hline G4 > Grupo membrana de CB pura + laser \\
\hline G5 > Grupo membrana de CB com própolis + laser \\
\hline
\end{tabular}

$\left({ }^{* *}\right)$ Legenda para identificação dos grupos

\begin{tabular}{|l|}
\hline ICU $=1$ reepitelização total \\
\hline ICU = 0 sem sinais de reepitelização \\
\hline $0<$ ICU $<1$ redução da área ulcerada \\
\hline ICU $<0$ aumento da área ulcerada \\
\hline
\end{tabular}

$\left(^{* * *}\right)$ Legenda para valores de ICU 


\subsection{GRUPO MEMBRANA DE CB PURA (G1)}

\subsubsection{Caso clínico 1 (úlcera G1a)}

Paciente C.S., 72 anos, negro, possuía uma úlcera de origem venosa devido a uma insuficiência circulatória do membro inferior direito, presente há 4 anos (Figura 18).

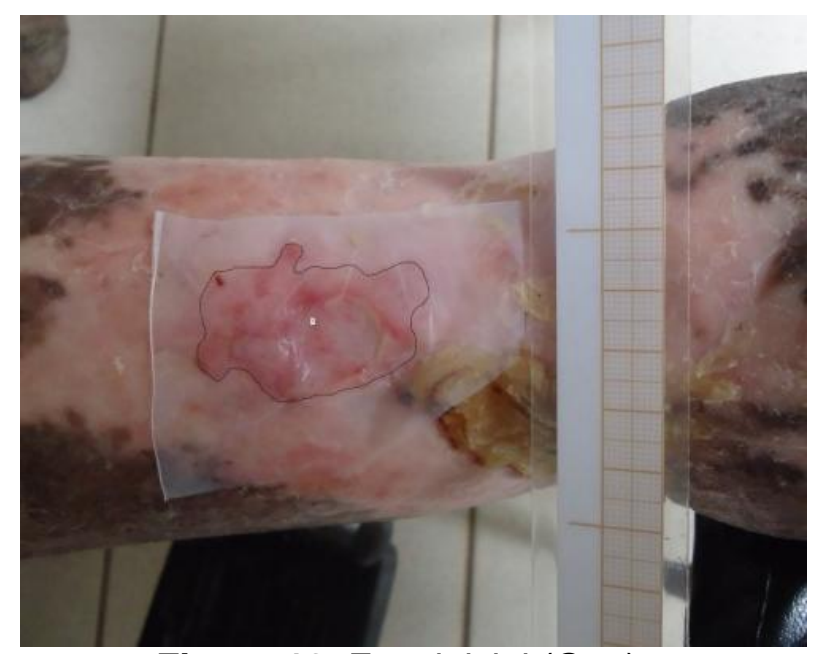

Figura 18: Foto inicial (G1a)

De acordo com a análise métrica computacional, a úlcera inicial se encontrava com uma área total de $7,199 \mathrm{~cm}^{2}$, porém logo após 15 dias de tratamento com a membrana de CB pura, houve importante regressão da região ulcerada e melhora do aspecto visual da úlcera (Figura 19):

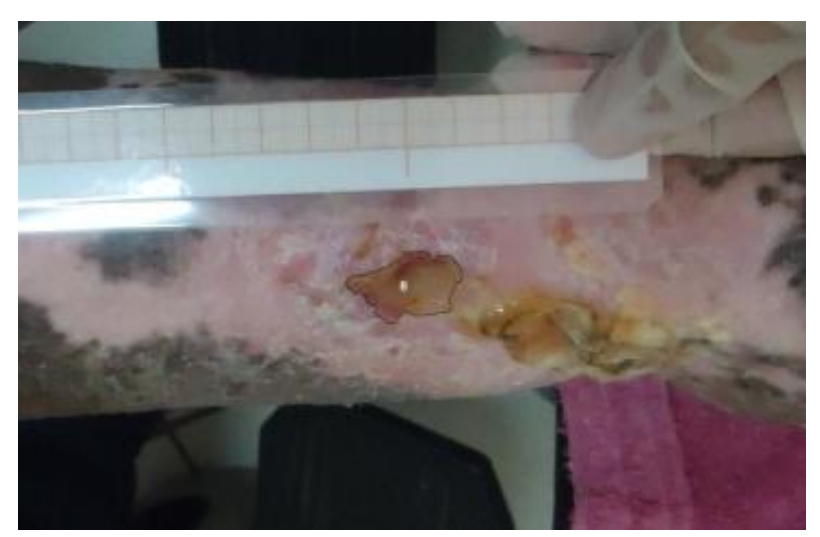

Figura 19: Após 15 dias de tratamento (G1a)

Após aproximadamente 30 dias de aplicação da CB pura (Figura 20), a úlcera apresentou uma taxa de diminuição de $83,8 \%$ (área final $=1,171 \mathrm{~cm}^{2}$ ), o que 
demonstra a aumento da velocidade de cicatrização comparando com o tempo já existente dessa úlcera, devido à presença do curativo.

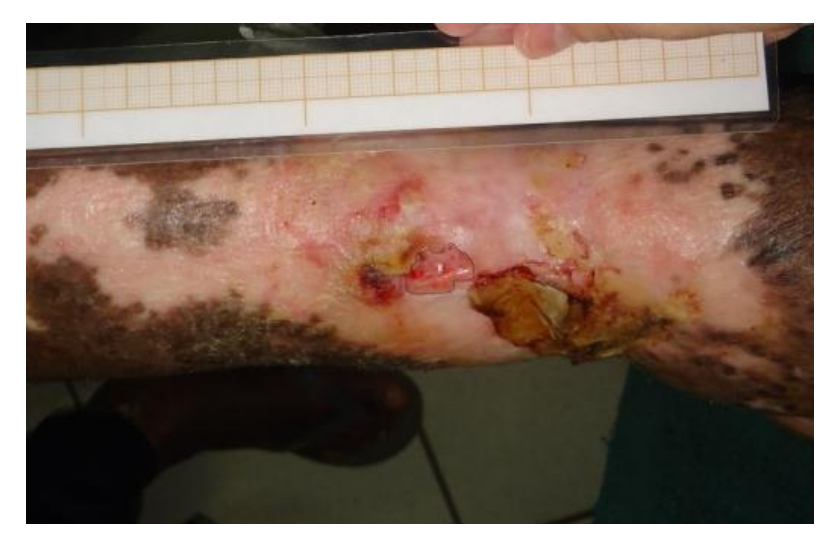

Figura 20: Após cerca de 30 dias de tratamento

O desafio maior do tratamento com esse paciente foi com relação a questão do nível de entendimento por parte do indivíduo, que retirou o curativo inúmeras vezes sem a permissão do pesquisador. No entanto, mesmo com a dificuldade em permanecer com a membrana de CB, foi possível notar uma diminuição significativa do tamanho da úlcera e rapidez de sua cicatrização.

Após o período de 30 dias, o paciente desenvolveu erisipela, que é uma celulite superficial com intenso comprometimento do plexo linfático subjacente causado por Streptococcus beta-hemolítico (BERNARDES et al., 2002), no membro acometido pela úlcera. Devido ao surgimento desta patologia, a aplicação da membrana foi interrompida por recomendação médica.

Pode-se sugerir que a continuação do acompanhamento por mais tempo provavelmente culminaria na reepitelização total dessa úlcera, levando em consideração o tempo de tratamento e a porcentagem de cicatrização no final desse período.

\subsubsection{Caso Clínico 2 (úlcera G1b)}

Paciente C.B.N., 69 anos, branca, cadeirante, diabética, foi submetida a uma cirurgia de colocação de prótese metálica de fixação externa em membro inferior, porém após a retirada desta prótese, não ocorreu a cicatrização no local. Esta úlcera existia há 1 ano e sua área inicial era de $0,732 \mathrm{~cm}^{2}$ (Figura 21). 


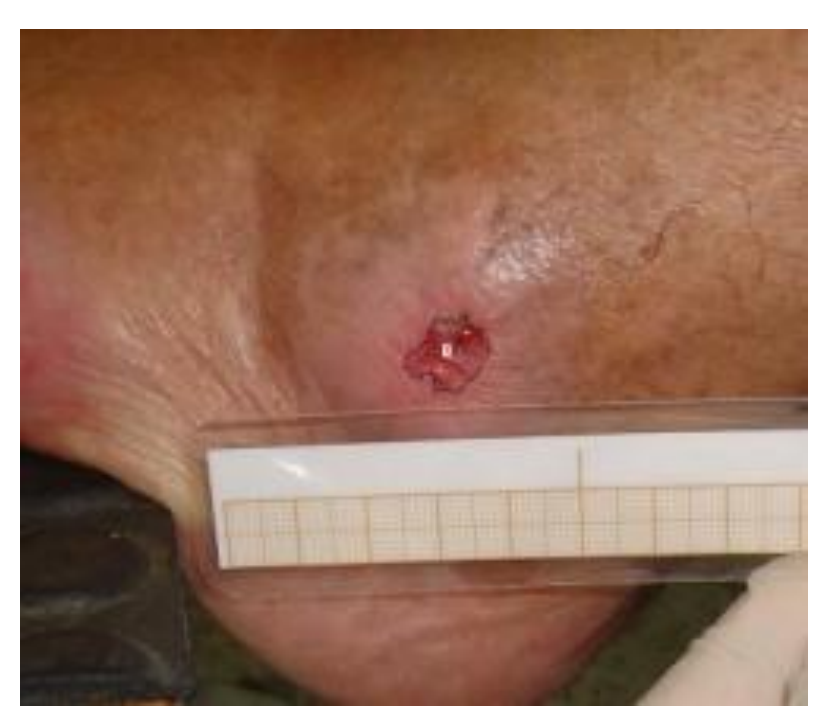

Figura 21: Foto inicial (G1b)

Após aproximadamente 7 dias da aplicação inicial da membrana de CB pura, a úlcera já apresentou regressão, respondendo positivamente ao tratamento (Figura 22):

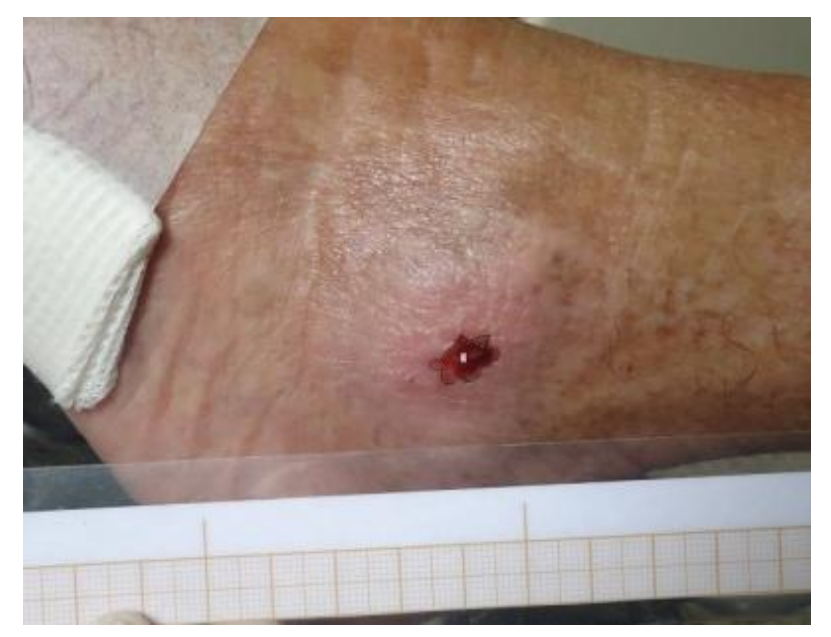

Figura 22: Após cerca de 7 dias do início do tratamento (G1b)

A Figura 23 demonstra a área ulcerada cerca de 15 dias após o início da aplicação da membrana: 


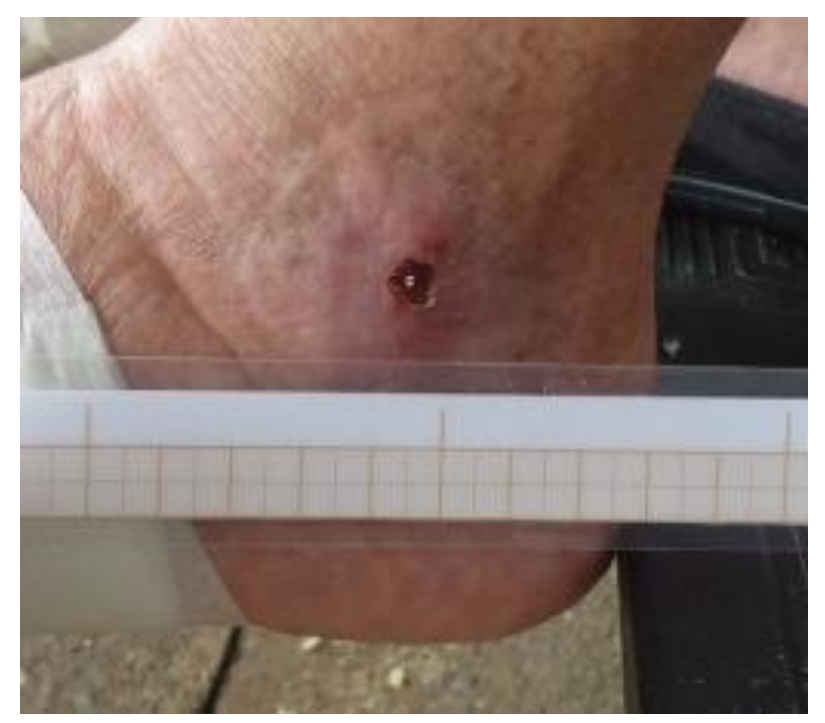

Figura 23: Cerca de 15 dias após início do tratamento

A reepitelização total desta úlcera aconteceu em torno de 24 dias após o início do tratamento, como pode ser visto na Figura 24:

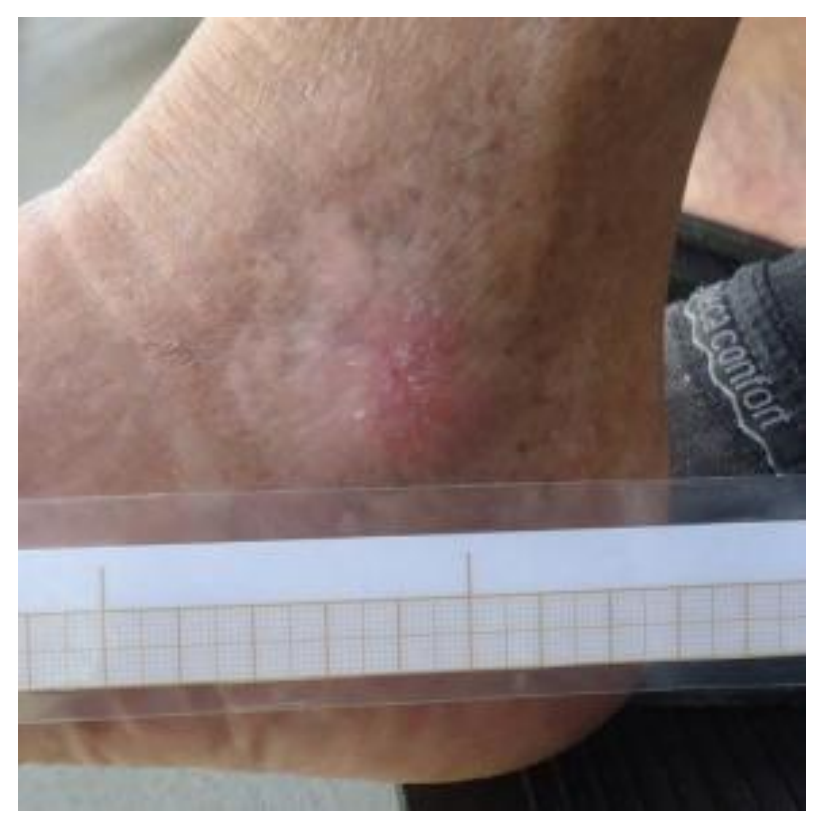

Figura 24: Reepitelização total em 24 dias

O tratamento com a membrana de CB se mostrou promissor devido à sua vantagem na orientação de células de reparo tecidual, o que ocorre até mesmo em úlceras com dificuldade de cicatrização por causa da diabete, como foi possível perceber no caso da G1b.

Outra situação encontrada nesta pesquisa foi a questão da baixa absorção da membrana de CB, ao contrário do que disse Geyer et al. (1994) em seu trabalho, 
onde descreveu a membrana de celulose como "altamente absorvível". Após a reepitelização do tecido lesionado abaixo da celulose aderida, a membrana é desprezada pelo próprio organismo, funcionando como uma crosta de tecido morto encontrada em úlceras após a cicatrização normal por segunda intenção.

Segundo Bäckdahl et al. (2006), a degradabilidade da celulose bacteriana (CB) não está completamente elucidada nem in vitro e nem in vivo. Mas, a degradação da celulose em tecidos animais e humanos é considerada limitada, em virtude da ausência de hidrolases que atacam a ligação $ß(1 \rightarrow 4)$ da cadeia de celulose. As pontes de hidrogênio dos grupos hidroxila, que mantém as cadeias da celulose juntas, fazem com que a celulose bacteriana tenha um alto grau de cristalinidade, baixa solubilidade, e degradação pobre in vivo (HELENIUS et al., 2006).

Apesar da ideia de um material completamente reabsorvível para ser utilizado na engenharia de tecidos ser interessante, as dificuldades enfrentadas com os materiais reabsorvíveis, como a otimização e sincronia do tempo de degradação com o tempo ideal para cicatrização e as propriedades mecânicas, levam a acreditar que um material não reabsorvível possa também ser vantajoso em relação à biomembranas reabsorvíveis (BÄCKDAHL et al., 2006; HELENIUS et al., 2006).

Helenius et al. (2006) em seu trabalho com a celulose bacteriana in vivo contribuíram para um maior conhecimento sobre este biomaterial e sua interação com células. Neste trabalho, celulose bacteriana foi implantada subcutaneamente em ratos, e sua biocompatibilidade in vivo foi avaliada. Os implantes de celulose bacteriana não causaram reação de corpo estranho, não apresentaram formação de fibrose ou encapsulamento, e o tecido conectivo dos ratos apresentou-se muito bem integrado às estruturas de celulose bacteriana. Após semanas do implante, o processo de remodelamento prosseguiu e os fibroblastos estavam completamente integrados na estrutura celulósica e sintetizaram colágeno. Neste estudo foi mostrado que a densidade do material influencia na morfologia e na invasão das células e, quanto maior a densidade da CB, menor a migração celular. Foi observado também pelos autores que as diferentes morfologias dos núcleos dos fibroblastos dependem da direção das nanofibras celulósicas e que o novo tecido formado apresentou melhora da vascularização. 


\subsection{GRUPO MEMBRANA DE CB PRÓPOLIS (G2)}

\subsubsection{Caso clínico 1 (úlcera G2a)}

Paciente M.I.R., 68 anos, negra, cadeirante, apresentava quadro de confusão mental, possuía uma úlcera de pressão Grau II existente há 1 mês, de $0,932 \mathrm{~cm}^{2} \mathrm{de}$ área inicial, como demonstra a Figura 25.

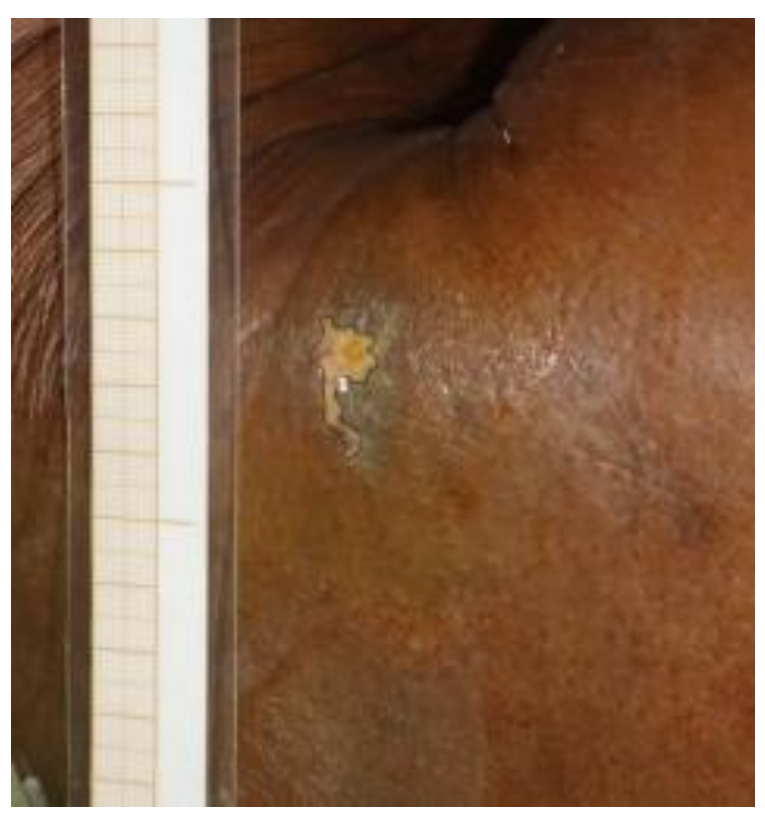

Figura 25: Foto inicial (G2a)

Aproximadamente 7 dias após a aplicação desta membrana houve cicatrização total desta úlcera, segundo a análise da Figura 26.

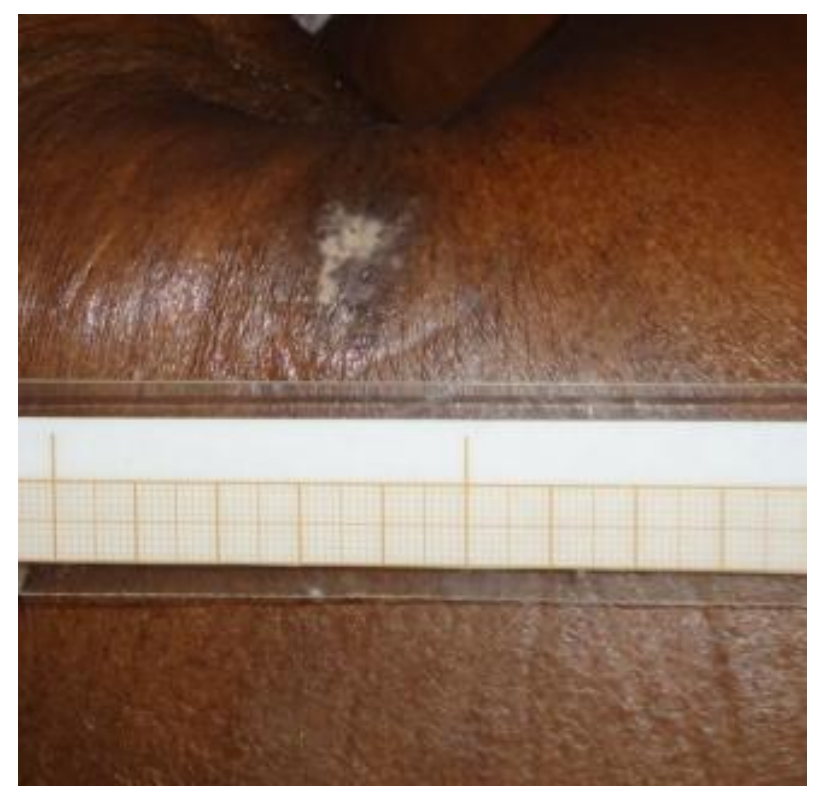

Figura 26: 7 dias após início do tratamento (G2a) 


\subsubsection{Caso Clínico 2 (úlcera G2b)}

Paciente D.S., 71 anos, branca, quadro de confusão mental, possuía úlcera de origem traumática, existente há 30 dias e com uma área inicial de $1,341 \mathrm{~cm}^{2}$ (Figura 27).

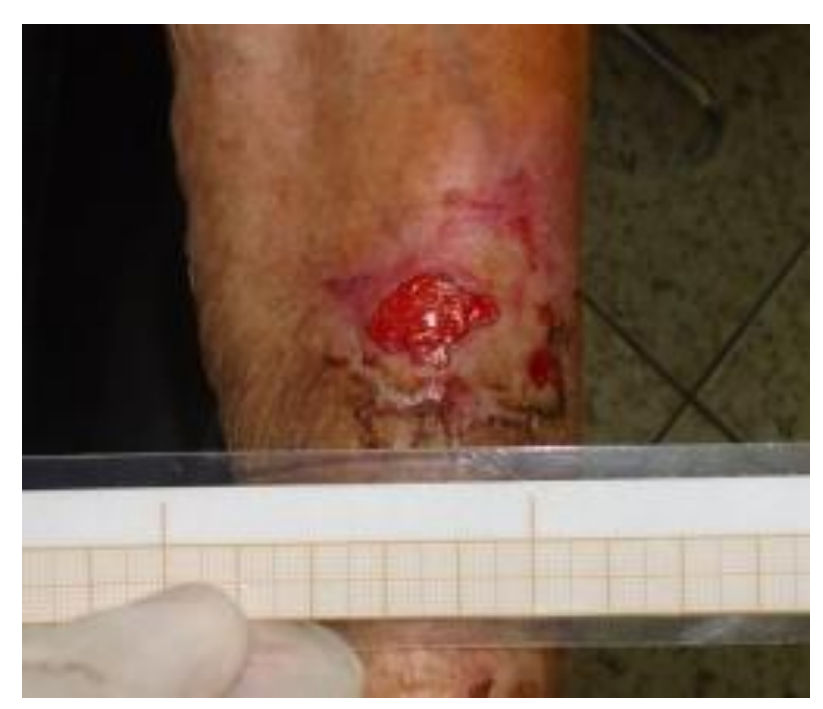

Figura 27: Foto inicial (G2b)

Após cerca de 7 dias do início do tratamento houve fechamento total da úlcera G2b, porém aparecimento de outra úlcera traumática próxima a esta (G2c) (Figura 28).

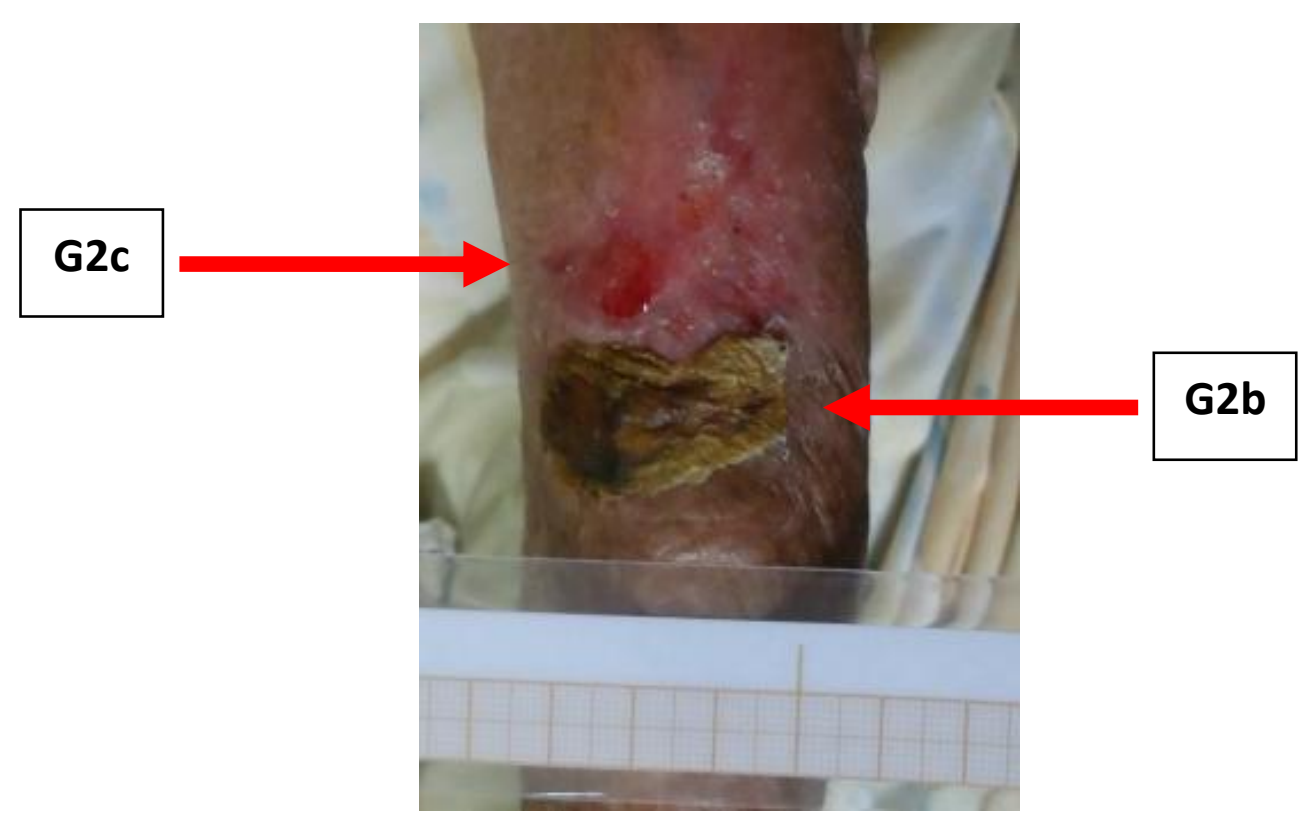


Figura 28: Após 7 dias do início do tratamento, fechamento de G2b e aparecimento de outra úlcera (G2c)

$\mathrm{Na}$ Figura 29, também fotografada aos 7 dias, podemos perceber a reepitelização total da úlcera G2b (após retirada dos restos da membrana com própolis, com cicatrização total abaixo da mesma):

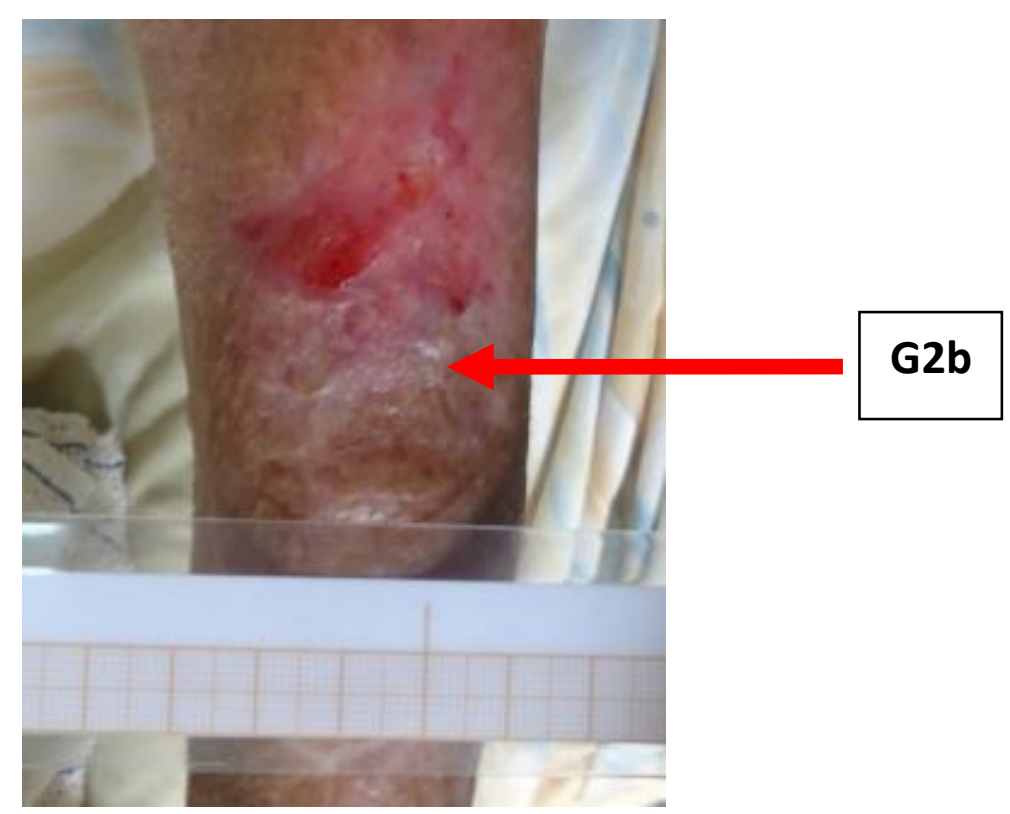

Figura 29: Cura total de G2b

5.2.3 Caso Clínico 3 (úlcera G2c)

Paciente D.S., 71 anos, branca, quadro de confusão mental, desenvolveu outra úlcera de origem traumática, existente há 7 dias que apresentava uma área inicial de 0,863 $\mathrm{cm}^{2}$, (figura 30).

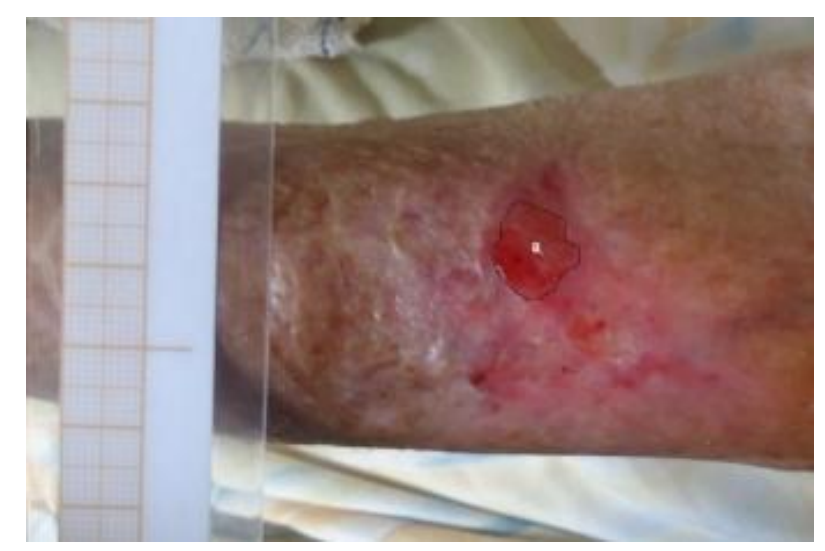

Figura 30: Análise da área inicial de G2c 
Essa úlcera obteve cicatrização total após 7 dias da aplicação da membrana de CB com própolis (Figura 31):

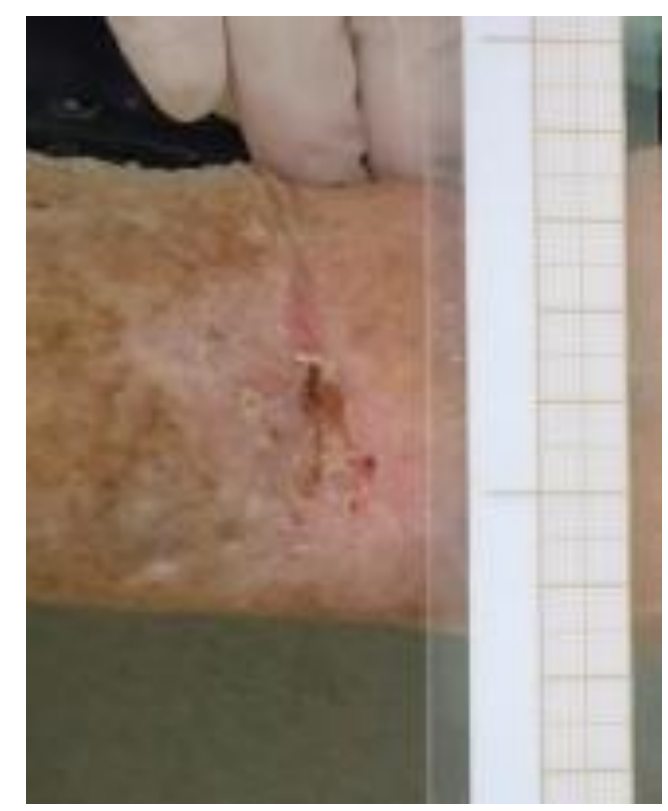

Figura 31: Reepitelização total de G2c em 7 dias

Apesar das úlceras pertencentes ao grupo de aplicação da membrana de CB com própolis terem sua cicatrização completa, a aplicação da mesma se mostrou difícil pelo fato desta membrana ser friável, pouco aderente à úlcera, além de não apresentar boa conformação no leito da úlcera. Por outro lado, este tipo de úlcera apresentado na paciente do G2 é a que possuiu maior facilidade de cicatrização em menor tempo, pois não estava associada a variáveis que poderiam influenciar no seu reparo tecidual como tabagismo, diabetes, insuficiência venosa, etc.

Silva et al. (2012) comprovou o efeito anti-inflamatório da própolis, que age liberando radicais livres durante o processo inflamatório (assim como os mecanismos convencionais de drogas anti-inflamatórias). A própolis também inibe o aumento da prostaglandina $E_{2}$ e a produção de óxido nítrico, sugerindo que essa inibição diminua o processo inflamatório. Apesar da facilidade de cicatrização da úlcera G2c, é possível que o curativo embebido com própolis possa ter auxiliado no controle da inflamação dessa lesão. 


\subsection{GRUPO LASER (G3)}

\subsubsection{Caso Clínico 1 (úlcera G3a)}

Paciente M.J.A.S., 74 anos, branca, acamada, pouco responsiva, possuía uma úlcera de pressão Grau III, existente há 4 anos. A foto inicial (Figura 32) demonstra a úlcera com área total inicial de $4,948 \mathrm{~cm}^{2}$.

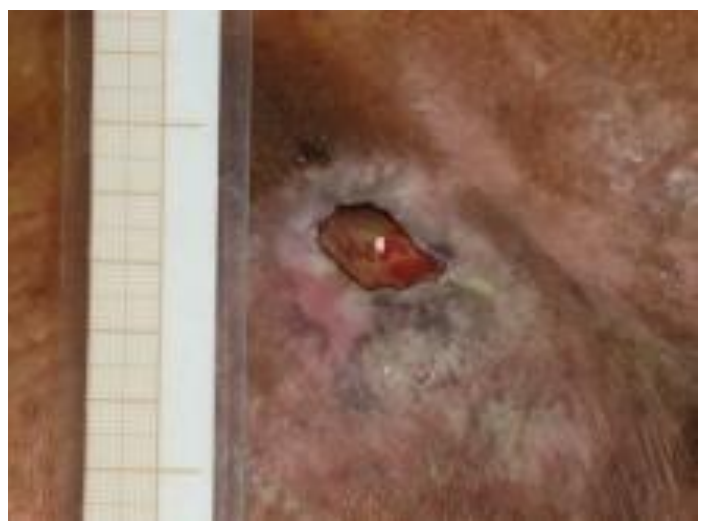

Figura 32: Foto inicial G3a

Após 7 dias de atendimento foi observada uma redução da área total da úlcera $\left(1,261 \mathrm{~cm}^{2}\right)$ (Figura 33) e melhora no aspecto visual das margens da úlcera, podendo indicar melhora do aporte sanguíneo. As Figuras 34, 35 e 36 indicam respectivamente os tempos de tratamento após 15,30 e 60 dias.

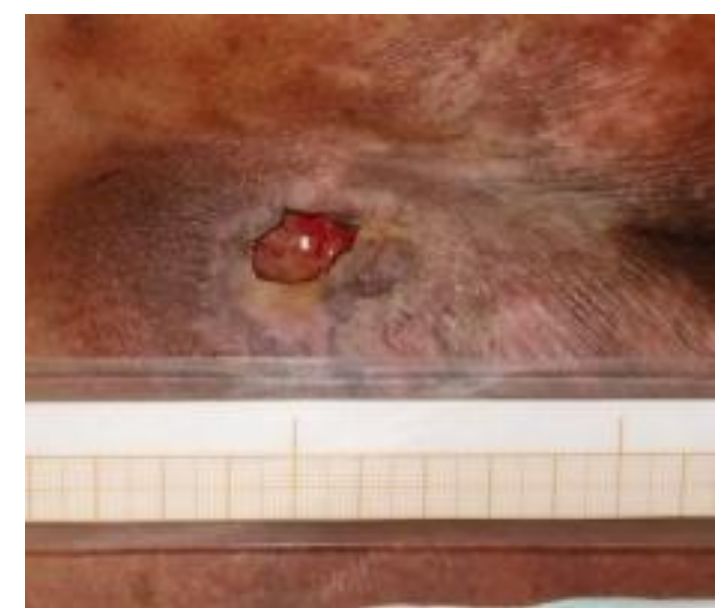

Figura 33: Após 7 dias do início das aplicações (G3a) 


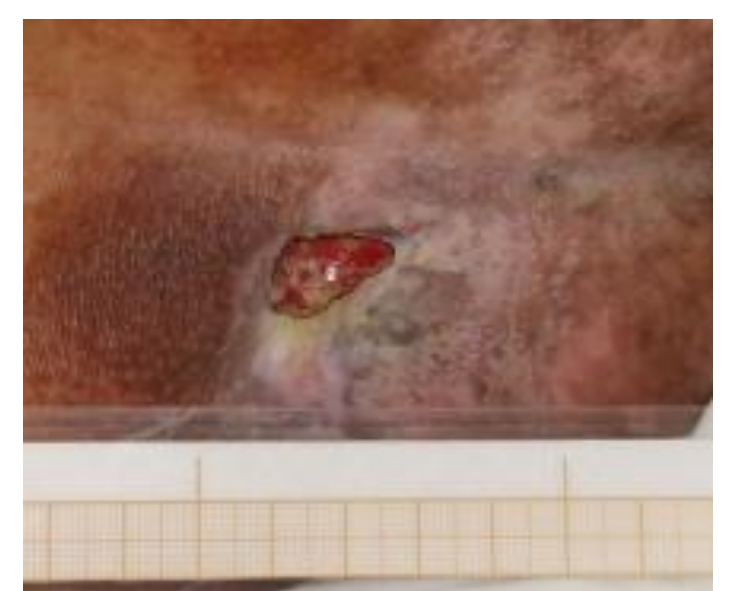

Figura 34: Após 15 dias do início das aplicações (G3a)

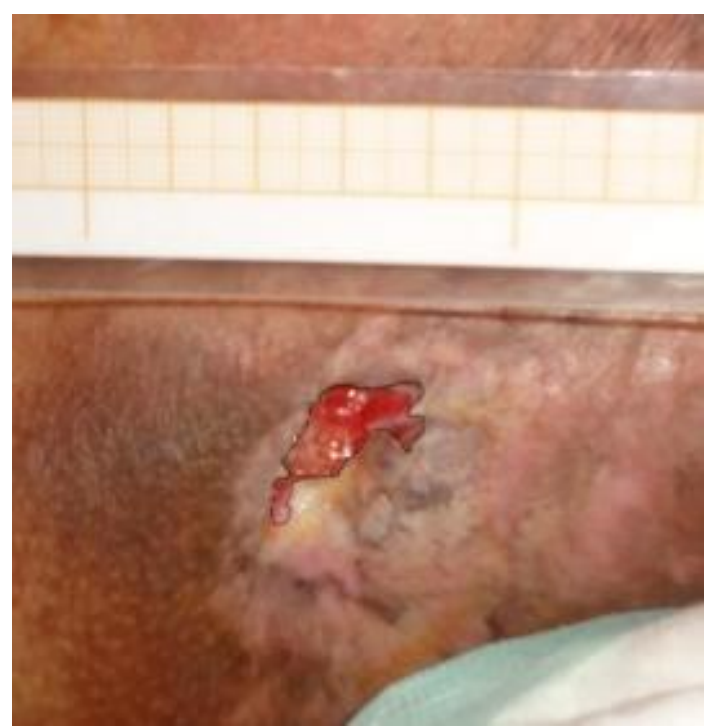

Figura 35: Após 30 dias do início das aplicações (G3a)

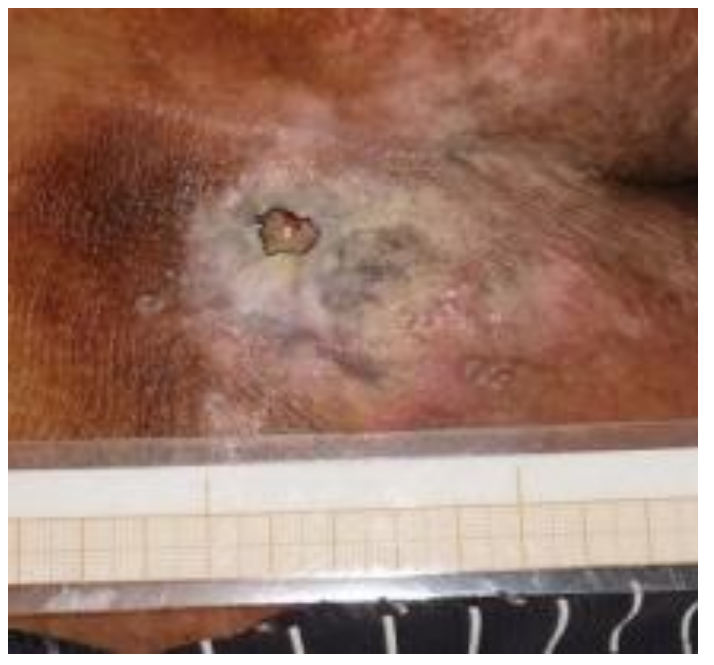

Figura 36: 60 dias após o início das aplicações (G3a) 
No final do acompanhamento (90 dias, Figura 37), a úlcera se encontrava com uma área total de $0,169 \mathrm{~cm}^{2}$, o que indicou uma redução considerável do tamanho da úlcera.

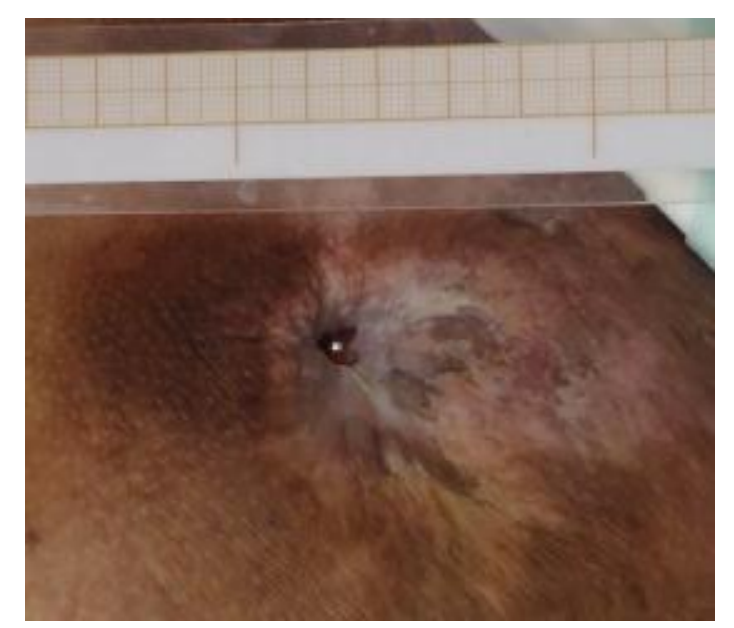

Figura 37: 90 dias após início das aplicações (G3a)

\subsubsection{Caso clínico 2 (úlcera G3b)}

Paciente C.B.N., 69 anos, branca, cadeirante, diabética, possuía uma úlcera cirúrgica há 1 ano, resultado da retirada de fixação externa usada para tratamento de fratura do pé esquerdo. A área inicial da úlcera era de $0,479 \mathrm{~cm}^{2}$, como podemos ver na Figura 38 e após 7 dias (Figura 39).

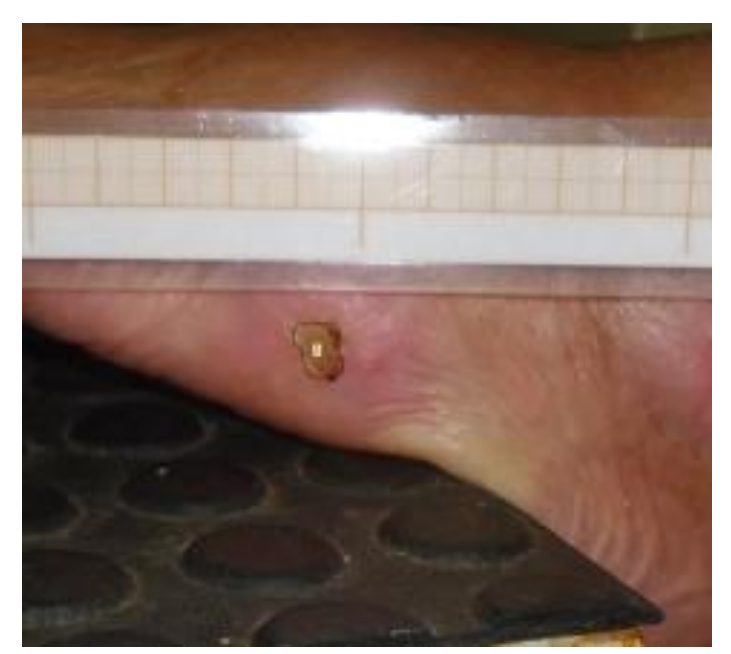

Figura 38: Foto inicial G3b 


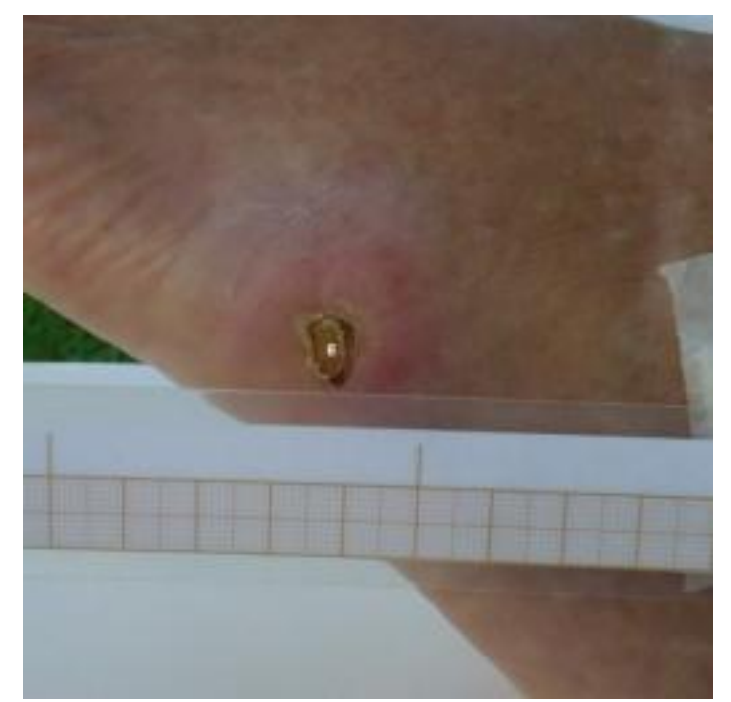

Figura 39: Após 7 dias do início do tratamento (G3b)

Apesar do agravante da paciente ser diabética, o tratamento foi efetivo, pois houve cicatrização total em apenas 20 dias (Figura 40), quando comparado ao tempo de existência da úlcera (1 ano).

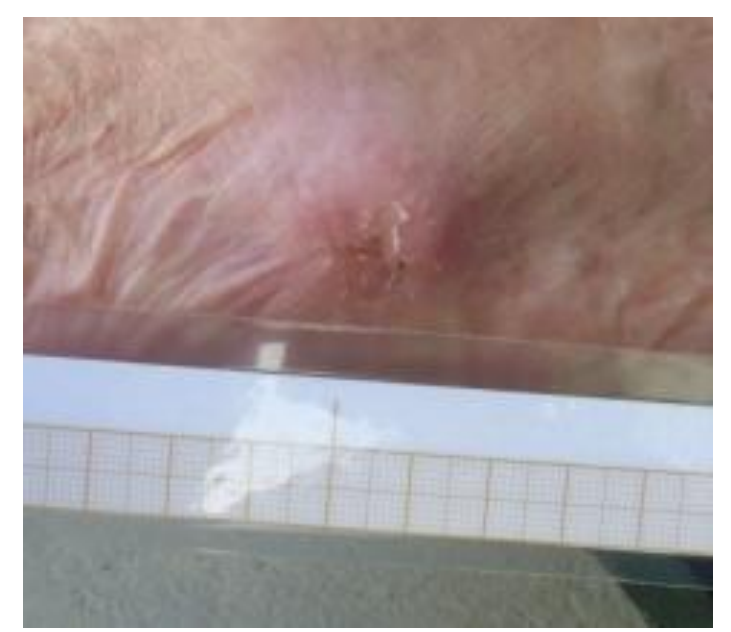

Figura 40: Após cerca de 20 dias do início do tratamento

A úlcera G3b apresentou-se inicialmente como uma úlcera pseudocicatrizada, pois havia uma crosta de tecido necrosado sobre o leito ulcerado. Essa camada de tecido morto é facilmente confundida com uma crosta saudável que permanece sobre uma úlcera em fase de cicatrização normal. Porém, ela indica que não ocorreu uma cicatrização eficaz, e abaixo dela, a úlcera ainda está presente, com sinais de inflamação. É necessário experiência por parte do avaliador, nesses casos, a fim de se evitar equívocos em relação à abordagem no tratamento desta 
patologia. Indica-se o desbridamento dessa úlcera (remoção de tecido necrótico para permitir a regeneração do tecido saudável subjacente), abrindo-a novamente para que fosse aplicado de fato o tratamento local. No entanto, como o tratamento escolhido foi o LBI, isso não foi necessário, já que o raio laser é absorvido pelo tecido e atua em tecidos adjacentes à lesão.

Segundo Karu et al. (1995); Pretel et al. (2002) e Demir et al. (2004) o LBI diminui a inflamação, estimula a cicatrização dos tecidos, a produção do ATP e a vascularização local e observou-se que isso ocorreu em relação à úlcera G3b, fazendo com que a crosta superior caísse sozinha, revelando sua total cicatrização.

Vários trabalhos com LBI (SCHINDL et al., 1999; ALBERTINI et al, 2004; ALBERTINI et al., 2007; KAZEMI-KHOO, 2006) utilizaram o laser no nível do vermelho visível, com um comprimento de onda próxima à $660 \mathrm{~nm}$ para tratamento de úlceras de pele e desordens inflamatórias gerais. Albertini et al. (2007) utilizaram uma intensidade de 7 Joules em tratamento de lesões cutâneas de ratos; neste presente trabalho foi utilizado o mesmo comprimento de onda mas com intensidade de 1 Joule e esta escolha, isto é, a redução da intensidade, foi feita na tentativa de se preservar o tecido subcutâneo exposto frente as aplicações do laser.

\subsection{GRUPO MEMBRANA DE CB PURA + LASER (G4)}

\subsubsection{Caso Clínico (úlcera G4a)}

Paciente S.S.S., 62 anos, branca, possuía uma úlcera de origem arterial (póstrombótica), existente há 2 anos com momentos de cura e recidivas constantes e quadro álgico intenso no local relatado pela paciente. Sua área inicial total era de $12,381 \mathrm{~cm}^{2}$. A Figura 41 demonstra a área inicial da G4a e a Figura 42, pós 7 dias de tratamento, área total de $1,259 \mathrm{~cm}^{2}$. 


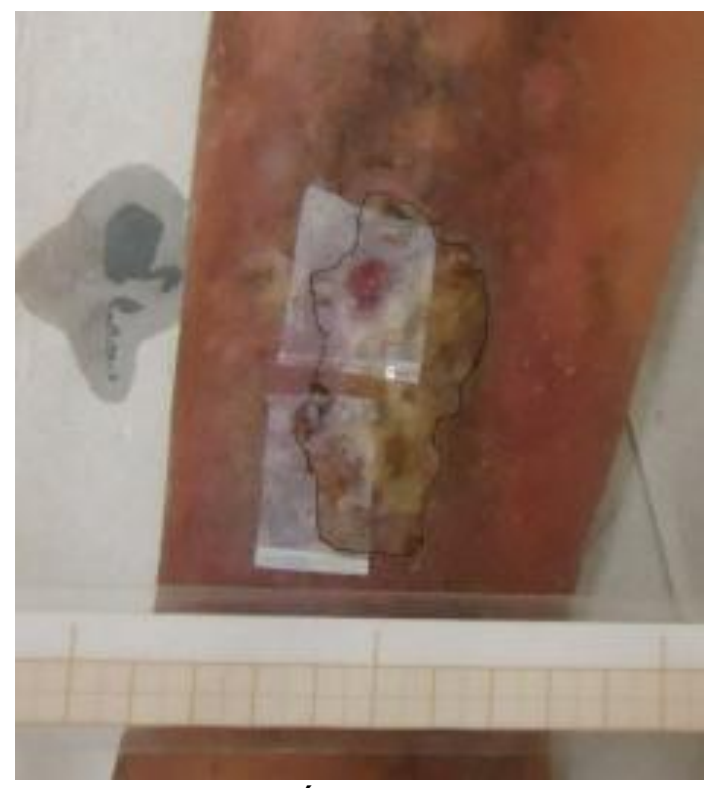

Figura 41: Área inicial de G4a

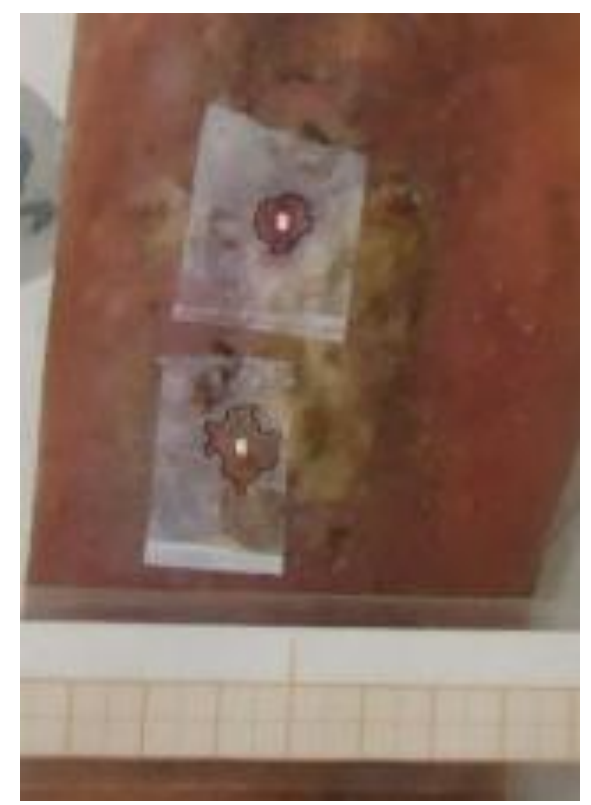

Figura 42: Após 7 dias do início do tratamento

Após 15 dias do início do tratamento (Figura 43), houve fechamento da úlcera, porém o tratamento continuou por mais 45 dias para que houvesse a certeza da não recidiva, melhora da dor e para que o aspecto visual da pele ao redor da úlcera (vascularização) melhorasse. As figuras 44 e 45 demonstram a evolução das úlceras após 30 e 60 dias respectivamente. 


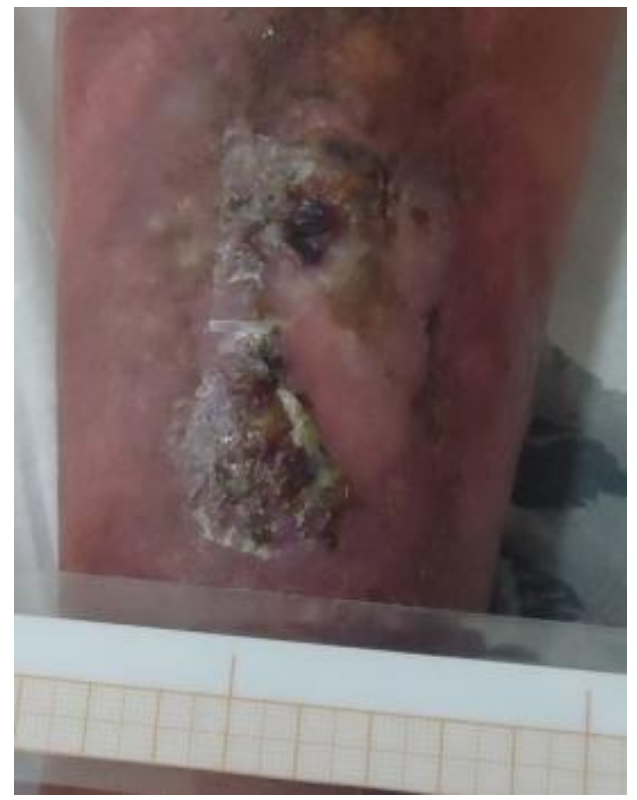

Figura 43: Após 15 dias do início do tratamento

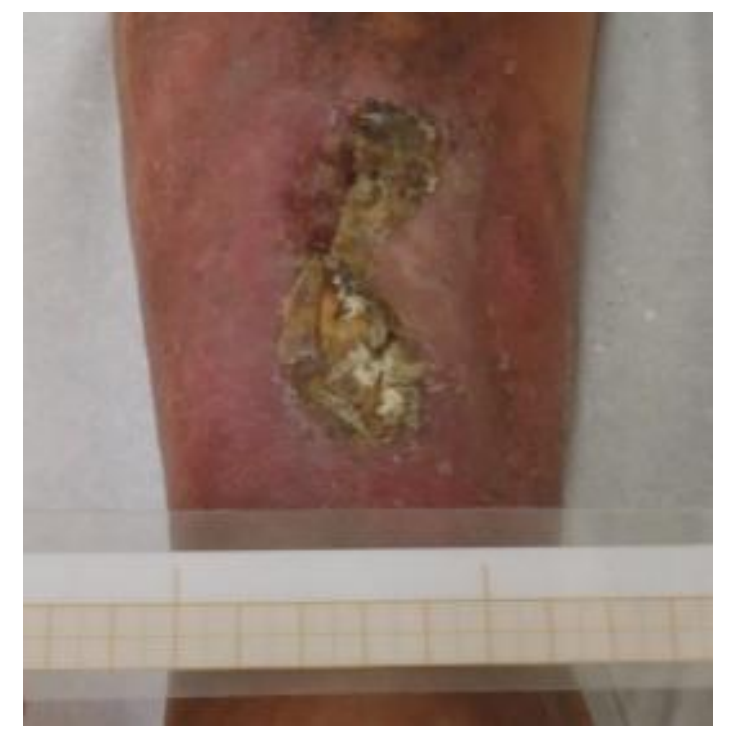

Figura 44: 30 dias após início do tratamento 


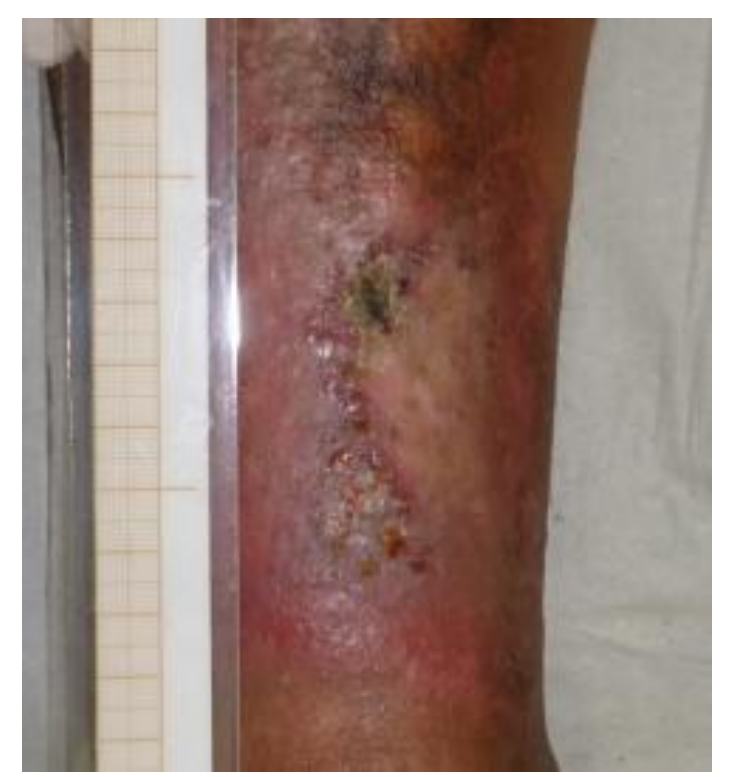

Figura 45: Aproximadamente 60 dias após início do tratamento

Além da cicatrização total da úlcera e nítida melhora do aspecto visual da região afetada e de toda a extremidade inferior dessa paciente, houve melhora do quadro álgico relatado pela mesma (achado clínico). O quadro doloroso causado pela úlcera de origem arterial é intenso e causa enorme inabilidade por parte do paciente, pois é considerado um tipo de úlcera grave (FURTADO, 2003), porém com a associação da membrana de CB pura e o LBI, essa situação pôde ser revertida, pois os dois recursos possuem efeito analgésico. Campana et al. (1998) afirmaram que o laser controla a produção de substâncias liberadas nos fenômenos de dor e inflamação como as prostaglandinas, prostaciclinas, histamina, serotonina, bradicinina, leucotrienos, etc.

Neste caso específico, a úlcera G4a completou sua cicatrização em 13 dias, porém o quadro álgico foi tão intenso que se decidiu manter a aplicação do laser por mais tempo (cerca de 50 dias), e ao final de aproximadamente 60 dias do inicio das aplicações, houve uma melhora neste quadro e também no aspecto da pele ao redor da antiga úlcera. É importante salientar que não houve recidiva, resultado muito significativo frente à gravidade deste tipo de lesão onde ocorrem alterações sistêmicas. 


\subsubsection{Caso Clínico 2 (úlcera G4b)}

Paciente M.I.R, 68 anos, negra, cadeirante, apresentava estado de confusão mental, possuía uma úlcera de pressão Grau II (Figura 46), existente há 3 meses e sua área inicial era de $1,091 \mathrm{~cm}^{2}$.

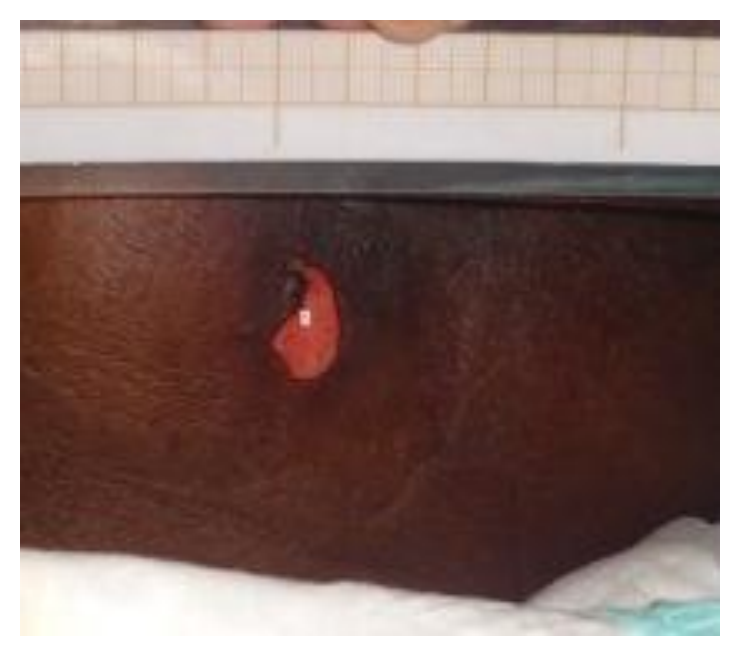

Figura 46: Foto inicial G4b

Após 10 dias do início do tratamento, houve aumento da área ulcerada por causa da falta de mudança de decúbito da paciente, que permanecia por longos períodos numa mesma posição, e isso levou a piora da úlcera de pressão, com evolução para Grau III, com área total de $12,953 \mathrm{~cm}^{2}$ (Figura 47).

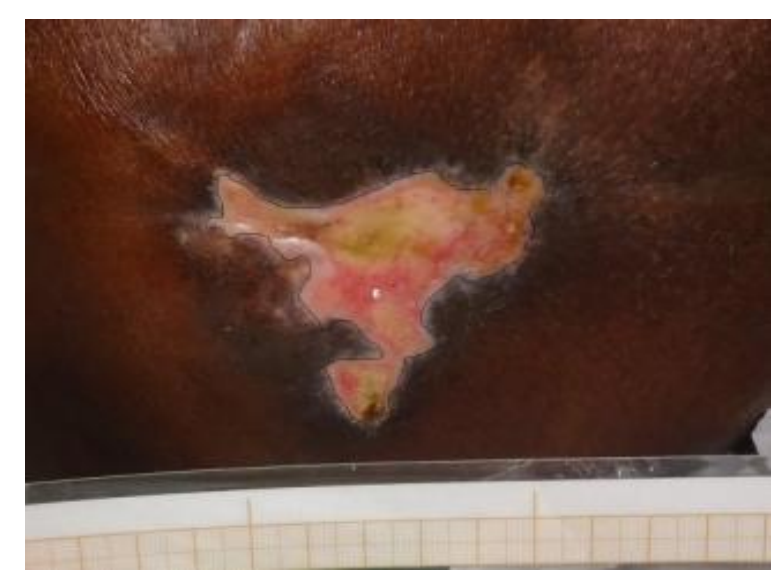

Figura 47: 10 dias após início do tratamento

Após 15 dias (Figura 48$)$ houve redução da área total $\left(8,775 \mathrm{~cm}^{2}\right)$ e subsequentemente após 30 dias, área total de 1,424 cm² (Figura 49); 60 dias, área total de $0,298 \mathrm{~cm}^{2}$ (Figura 50), e após 90 dias (Figura 51) com a cura total da úlcera. 


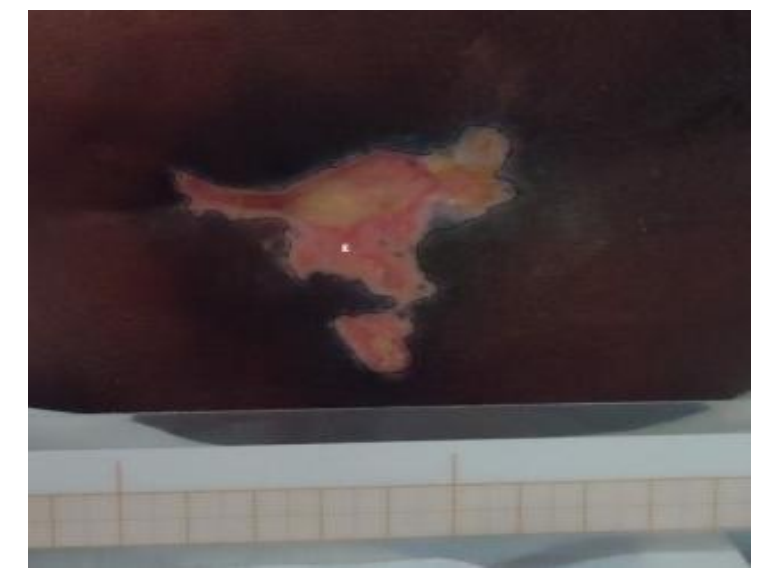

Figura 48: Após 15 dias de tratamento

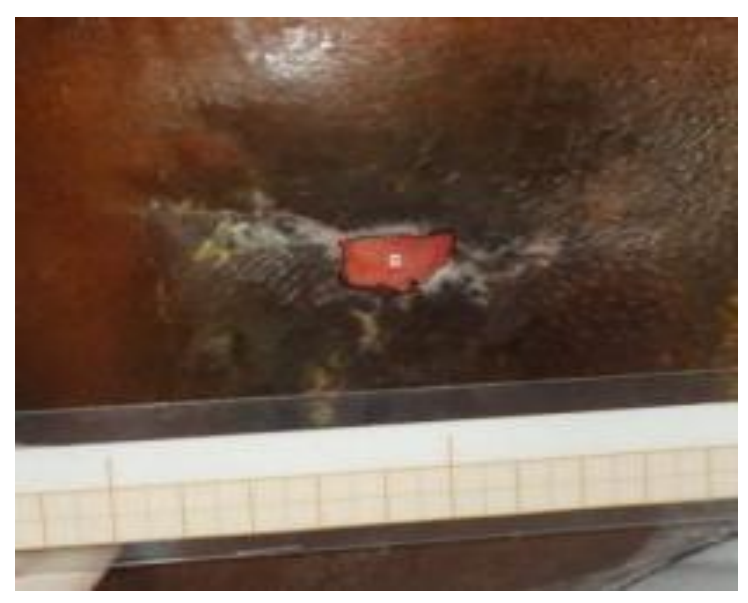

Figura 49: 30 dias após início do tratamento

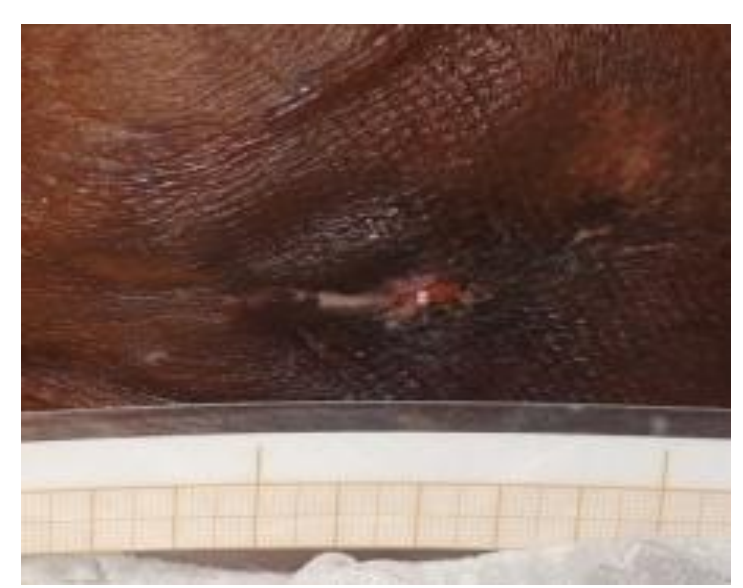

Figura 50: 60 dias após início do tratamento 


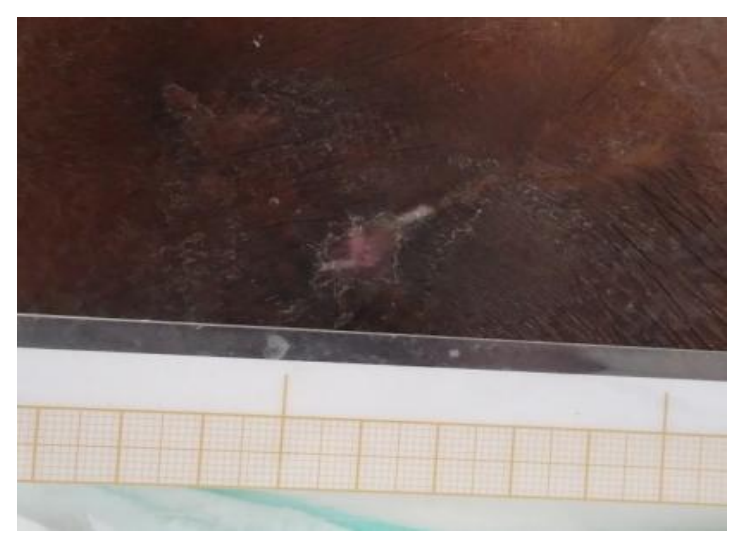

Figura 51: Aproximadamente 90 dias após início do tratamento, cura total

De acordo com os resultados, a associação entre a CB pura e o LBI potencializou os efeitos regenerativos do tecido lesionado e também acelerou o tempo de recuperação dessa úlcera crônica.

\subsubsection{Caso Clínico 3 (úlcera G4c)}

Paciente O.V.C.V, 80 anos, acamada, estado metal de confusão, possuía uma úlcera de pressão Grau III existente há 6 meses. A área total inicial era de 4,26 $\mathrm{cm}^{2}$ (Figura 52) e após 7 dias de tratamento, área total era de 4,193 cm² (Figura 53).

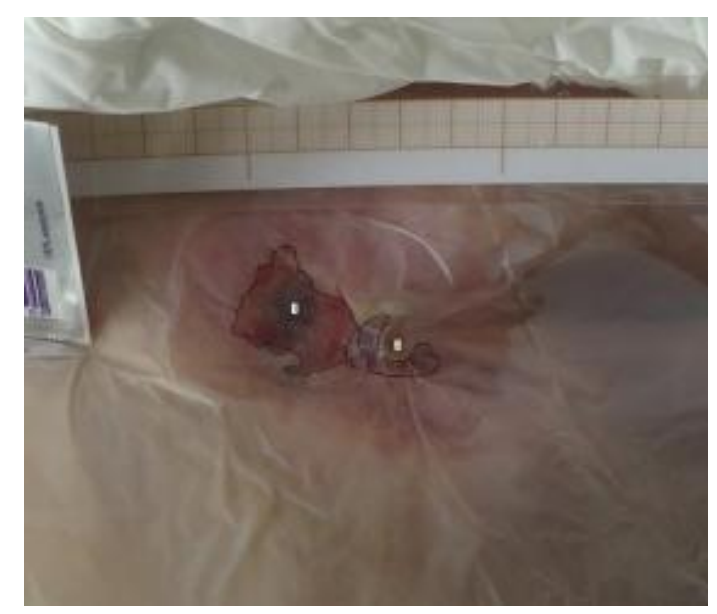

Figura 52: G4c, foto inicial 


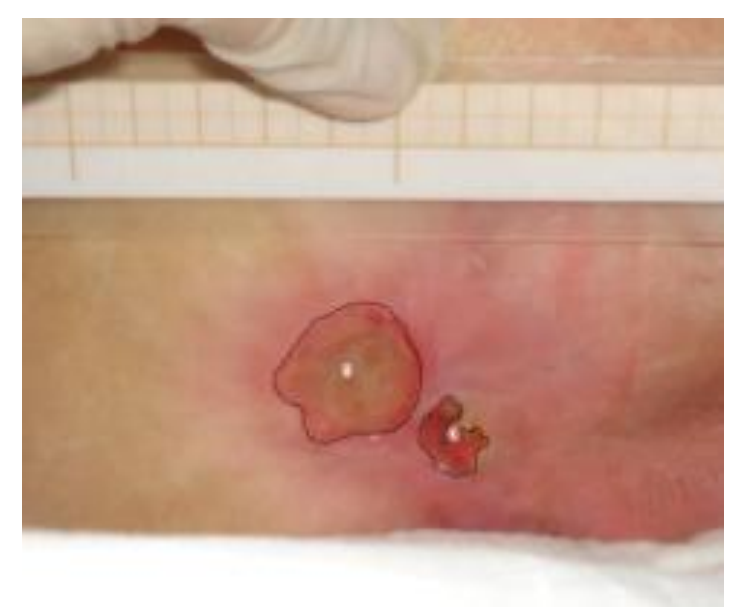

Figura 53: Após 7 dias de tratamento

Após 15 dias de tratamento (Figura 54), houve aumento da úlcera (área total de $5,768 \mathrm{~cm}^{2}$ ), apesar da insistência na orientação junto aos cuidadores para mudança de decúbito da paciente. É possível notar através da Figura 54 a área avermelhada ao redor e mais superiormente a úlcera, resultado da pressão excessiva no local; este eritema, acompanhado de aumento da temperatura local indicou a formação de úlcera de pressão Grau I.

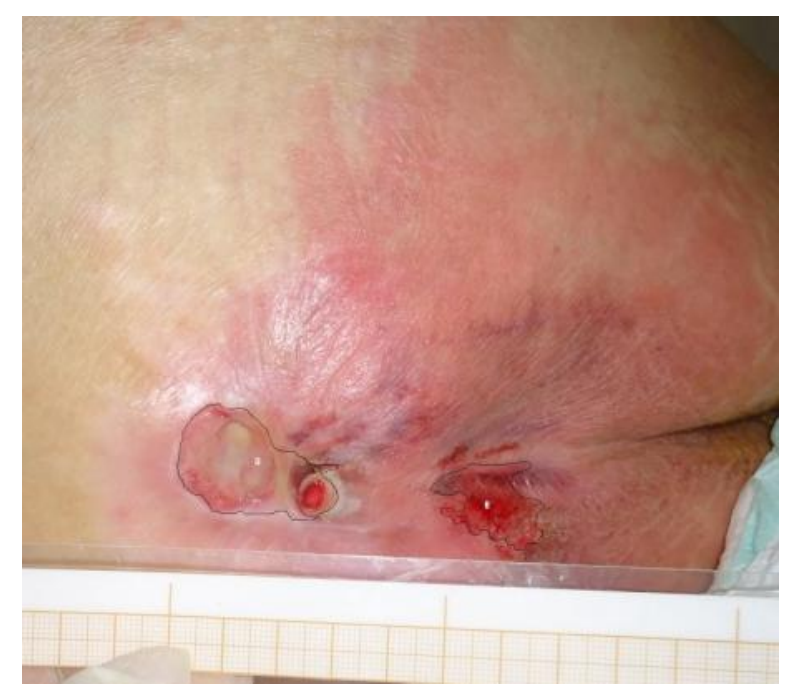

Figura 54: 15 dias após inicio do tratamento

A úlcera continuou aumentando após 30 dias do início das aplicações, e tomou grande proporção, alastrando-se pela região que anteriormente se apresentava como eritema mesmo com toda persistência frente às orientações quanto a alternância de decúbito com área total de $41,870 \mathrm{~cm}^{2}$ (Figura 55). 


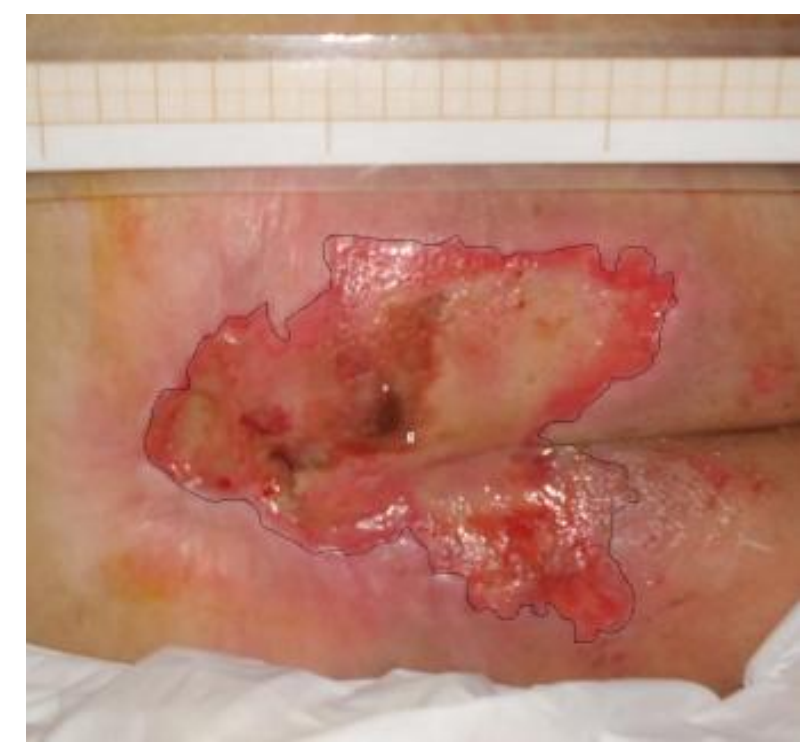

Figura 55: Após 30 dias do início do tratamento

Sendo assim, após inúmeras orientações e continuidade das aplicações, houve regressão da úlcera após cerca de 60 dias do início do tratamento, com diminuição da área ulcerada, área total de 2,996 cm², como é possível notar na Figura 56.

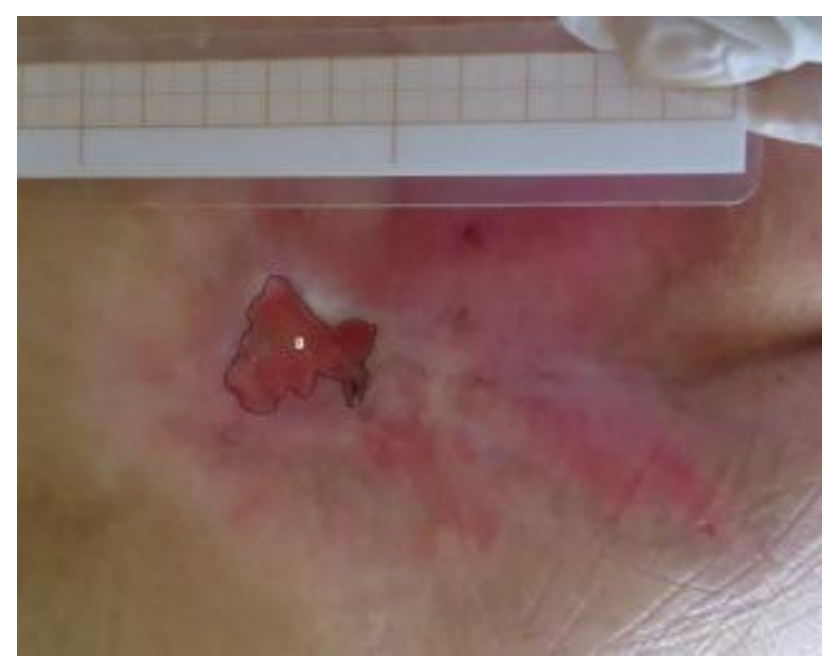

Figura 56: 60 dias após início do tratamento

No final do acompanhamento, cerca de 90 dias, houve grande melhora da úlcera (Figura 57), com diminuição significativa de sua área (área final: 2,2 cm²) e melhora no aspecto visual do local. 


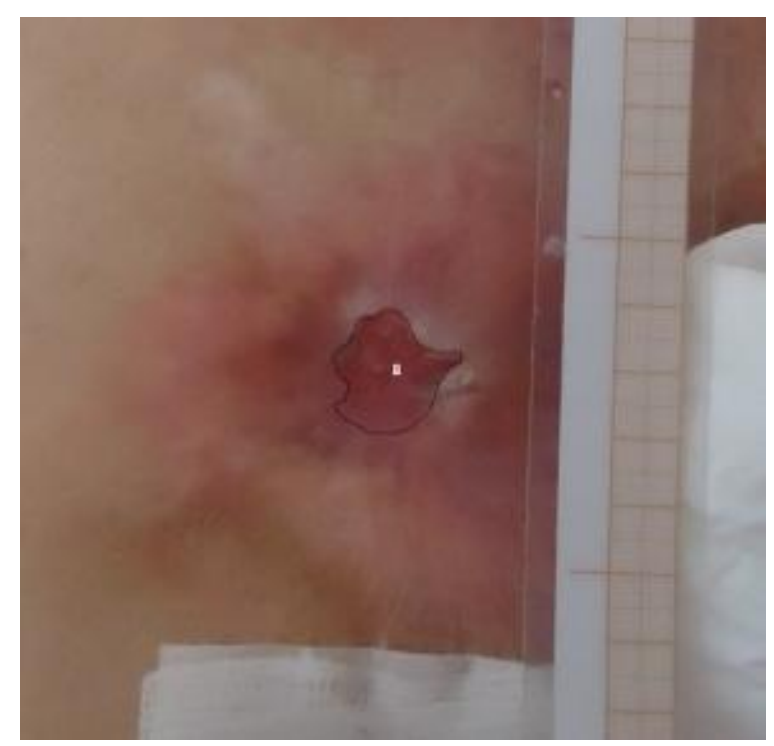

Figura 57: 90 dias do inicio do tratamento

O tratamento seria mais efetivo se houvesse maior entendimento dos mecanismos de formação da úlcera de pressão por parte dos cuidadores. É necessário um cuidado especial para evitar que elas apareçam como a mudança de decúbito do paciente a cada 3 horas. A prevenção é importante uma vez que esse tipo de úlcera é uma porta de entrada para microorganismos patogênicos. Além disso, geralmente elas se localizam em regiões que entram em contato com urina e fezes, permanecendo úmidas e agravando o quadro.

A úlcera G4c foi a única deste grupo que não obteve total cicatrização e é possível sugerir que isso ocorreu pela falta de comprometimento dos cuidadores quanto ao tratamento. Apesar disso, houve melhora do quadro, com taxa de cicatrização da úlcera de quase 50\% comparado com seu tamanho inicial. Por outro lado, se levarmos em consideração o tempo onde se observou a maior área da úlcera (trigésimo dia, 41,870 $\mathrm{cm}^{2}$ ), em relação ao tempo do tratamento entre o trigésimo e o nonagésimo dia e o tamanho da úlcera (60 dias; área final de $2,2 \mathrm{~cm}^{2}$ ), a porcentagem de melhora nesse período foi de $94,75 \%$, resultado muito positivo e que nos possibilita validar a associação entre membrana de CB e o laser. 


\subsection{GRUPO MEMBRANA DE CB PRÓPOLIS + LASER (G5)}

\subsubsection{Caso Clínico 1 (úlcera G5a)}

Paciente M.I.R., 68 anos, negra, cadeirante, estado de confusão mental, possuía uma úlcera de pressão Grau II existente há 6 meses, com área inicial de $2,069 \mathrm{~cm}^{2}$ (Figura 58).

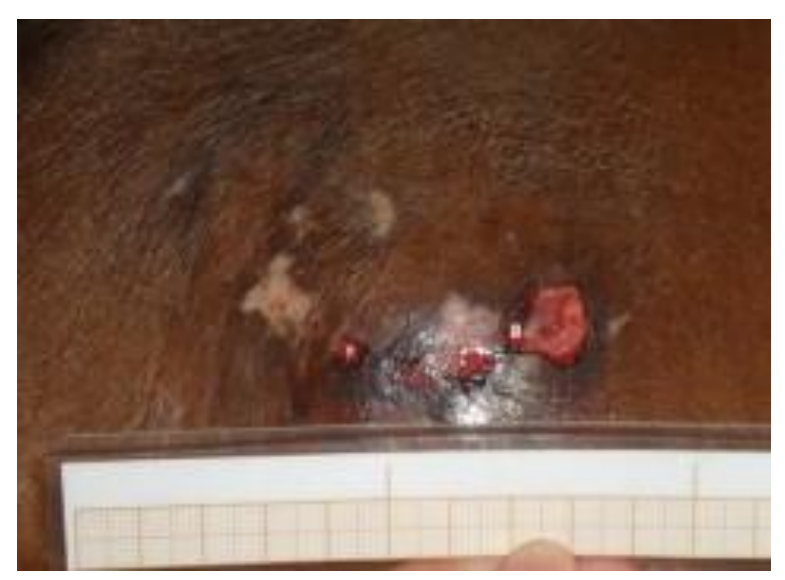

Figura 58: Foto inicial G5a

Aproximadamente 7 dias após o início do tratamento, houve aumento da área úlcera para 7,536 cm², como podemos observar na Figura 59, sendo que após 15 dias (Figura 60), ocorreu redução (área total de $3,711 \mathrm{~cm}^{2}$ ).

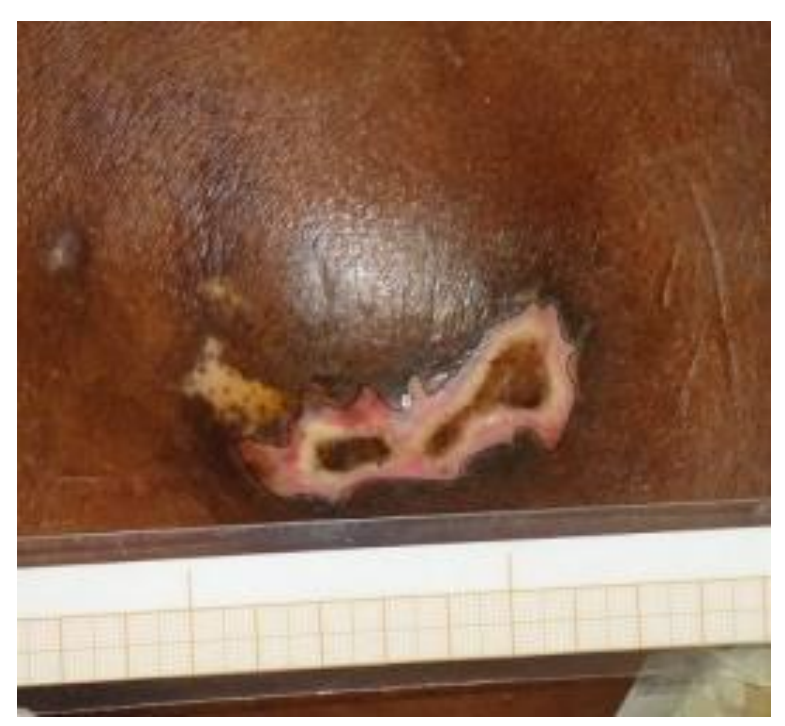

Figura 59: Após 7 dias de tratamento 


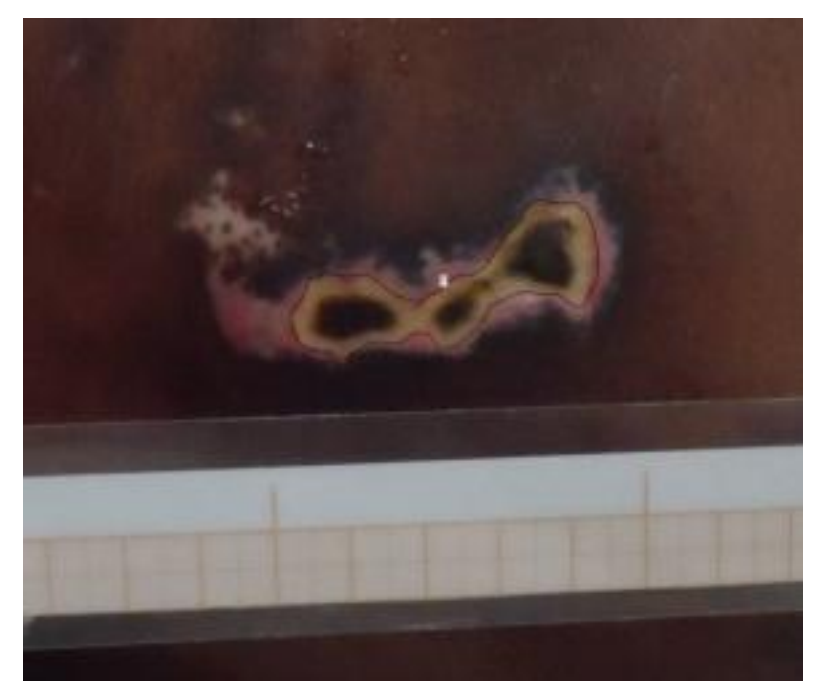

Figura 60: 15 dias após inicio do tratamento

Após 30 dias, a úlcera diminui mais seu tamanho (área total de 2,78 cm², Figura 61) e foi possível observar a presença de esfacelo, que é um tecido necrosado de consistência delgada, mucóide e macia que pode estar firme ou frouxamente aderido ao leito da úlcera ou margens.

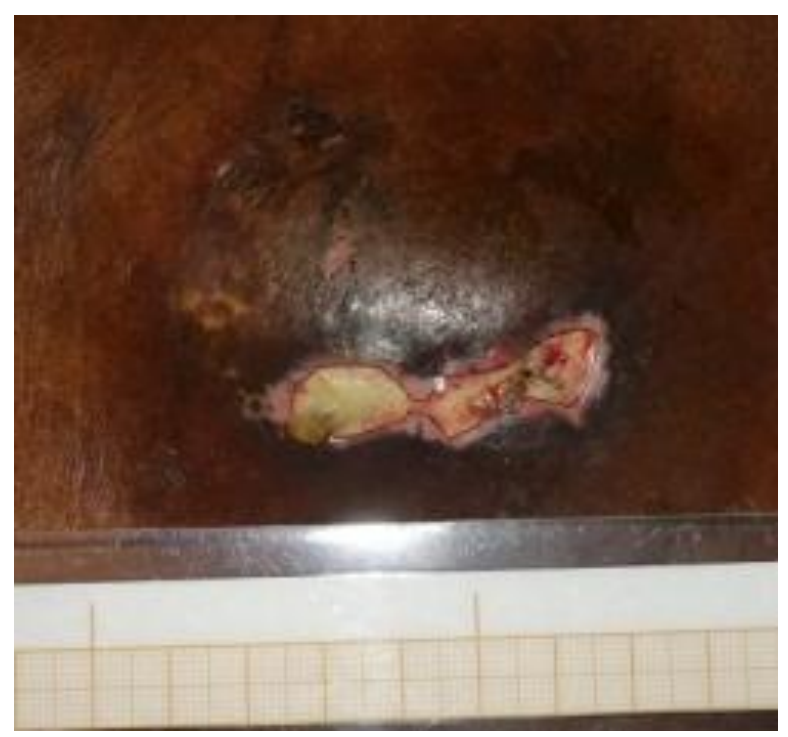

Figura 61: 30 dias após inicio do tratamento

Assim como no G2, houve grande dificuldade da membrana de CB com própolis de se aderir no leito das úlceras deste grupo, porém com a associação do laser, no caso da G5a, houve sucesso na reepitelização da úlcera representado nas figuras 62 (60 dias, área total de $0,863 \mathrm{~cm}^{2}$ ) e 63 (90 dias, cura). 


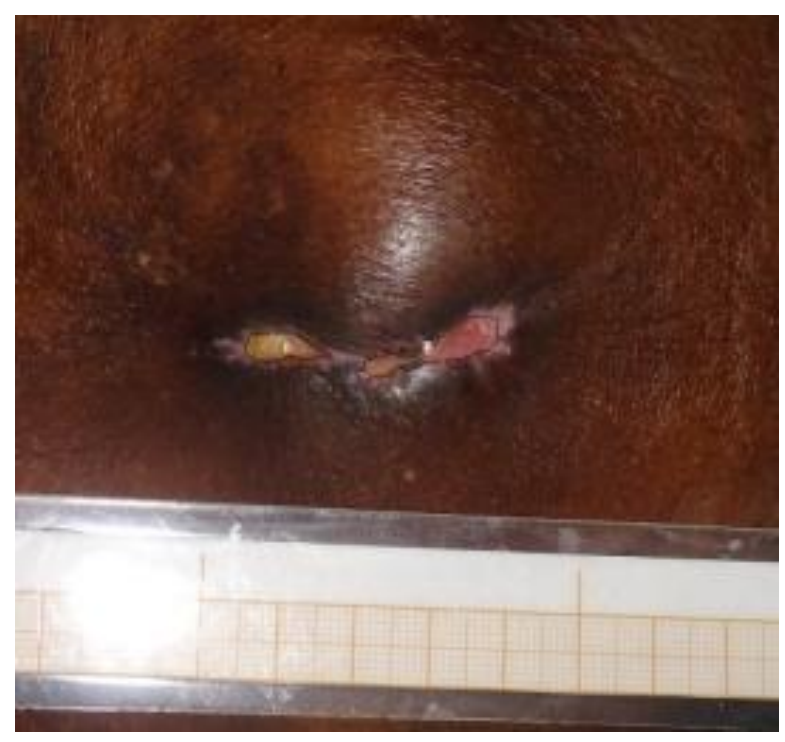

Figura 62: 60 dias após inicio do tratamento

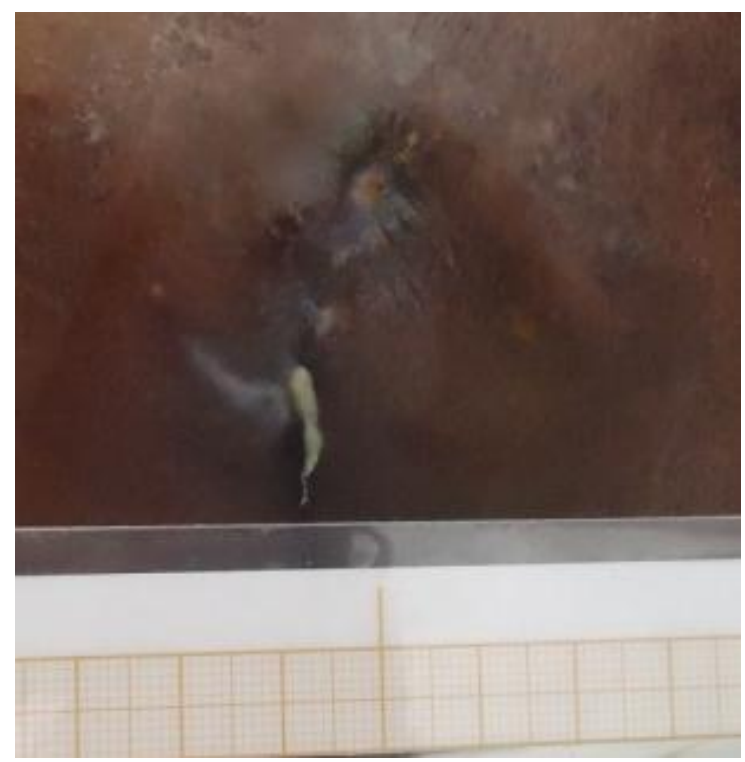

Figura 63: 90 dias após inicio do tratamento, cicatrização total

De acordo com o caso citado acima e o teste de absorbância do LBI realizado e seus dados quanto à passagem do laser através da membrana de CB com própolis, pôde-se sugerir que o LBI manteve seu efeito cicatrizante, mesmo com diminuição da potência do raio que atingiu o tecido lesionado.

\subsubsection{Caso Clínico 2 (G5b)}

Paciente J.B., 70 anos, branco, diabético não-controlado, possuía uma úlcera diabética no pé direito (pé diabético), existente há 5 anos, que apresentava infecção por Pseudomonas auriginosa, Stafilococcus aureus e Candida sp. (de acordo com 
exame laboratorial realizado). Sua área inicial era de $2,01 \mathrm{~cm}^{2}$, como demonstra a figura 64.

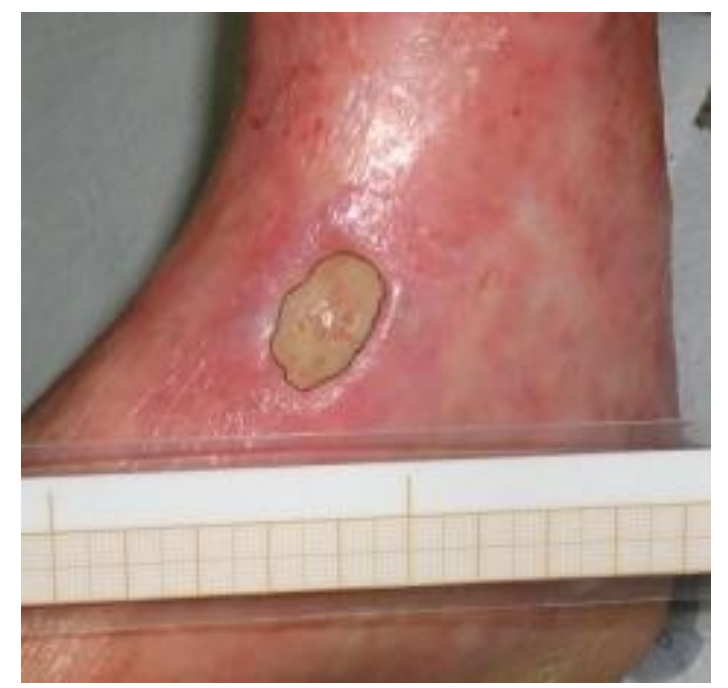

Figura 64: Foto inicial G5b

A úlcera G5b não apresentou uma melhora significativa com variação da taxa de cicatrização durante os períodos de 7 a 60 dias. Isto é, aos 7 dias a área total foi de 2,293 $\mathrm{cm}^{2}$ (figuras 65); aos15 dias, área total de 2,641 $\mathrm{cm}^{2}$ (Figura 66); aos 30 dias, área total de 2,405 $\mathrm{cm}^{2}$ (Figura 67) e aos 60 dias, área total de 2,444 $\mathrm{cm}^{2}$ (Figura 68).

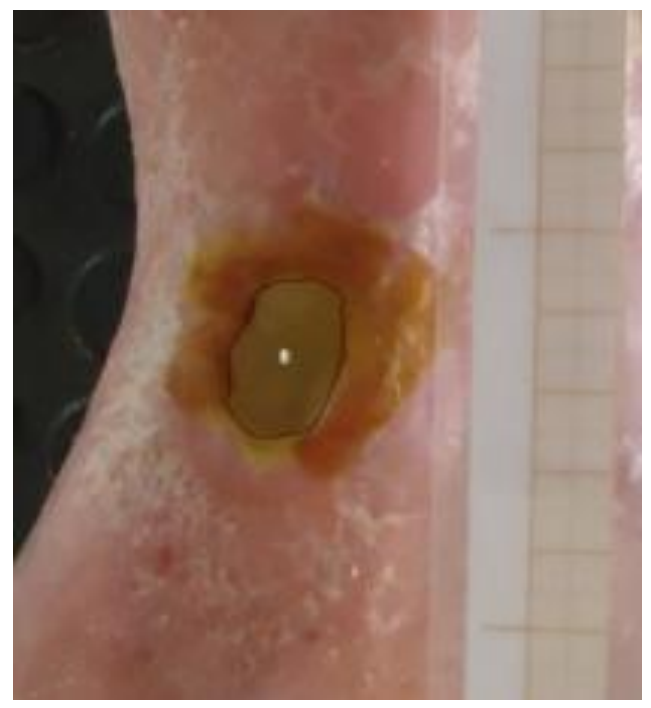

Figura 65: Cerca de 7 dias após inicio do tratamento 


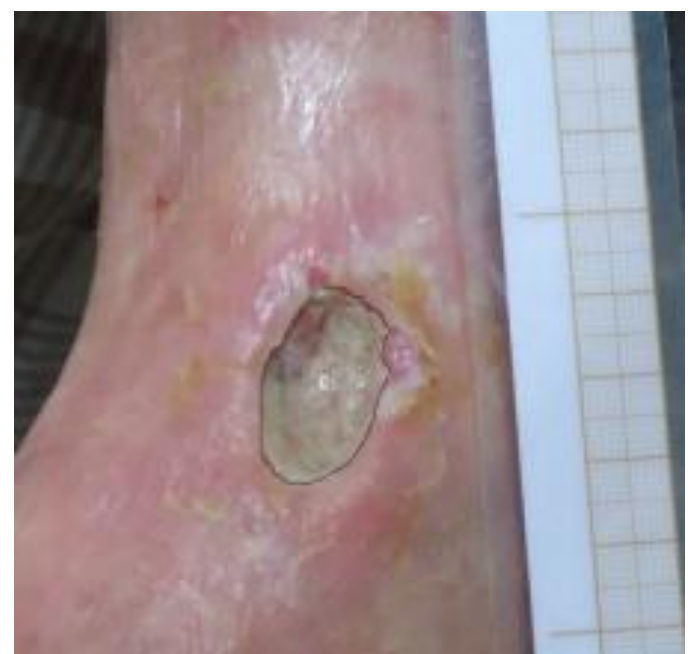

Figura 66: 15 dias após inicio do tratamento

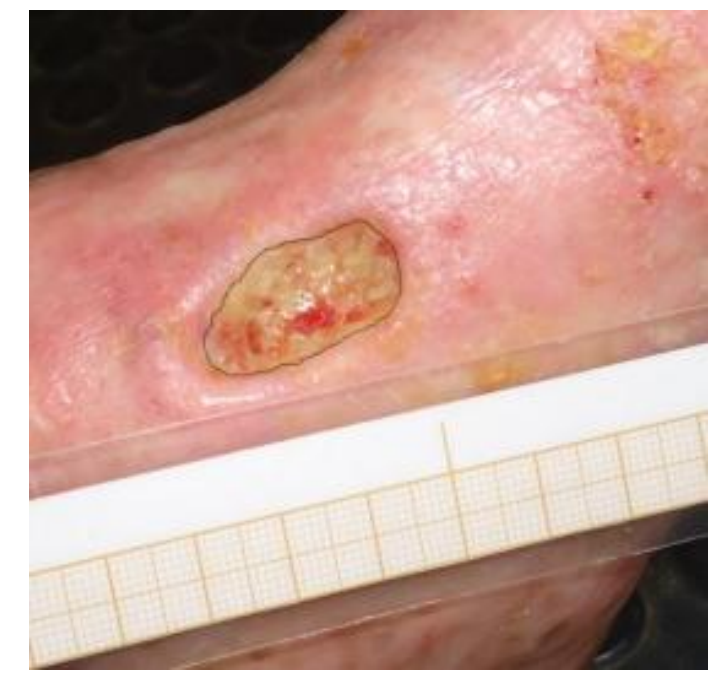

Figura 67: 30 dias após inicio do tratamento

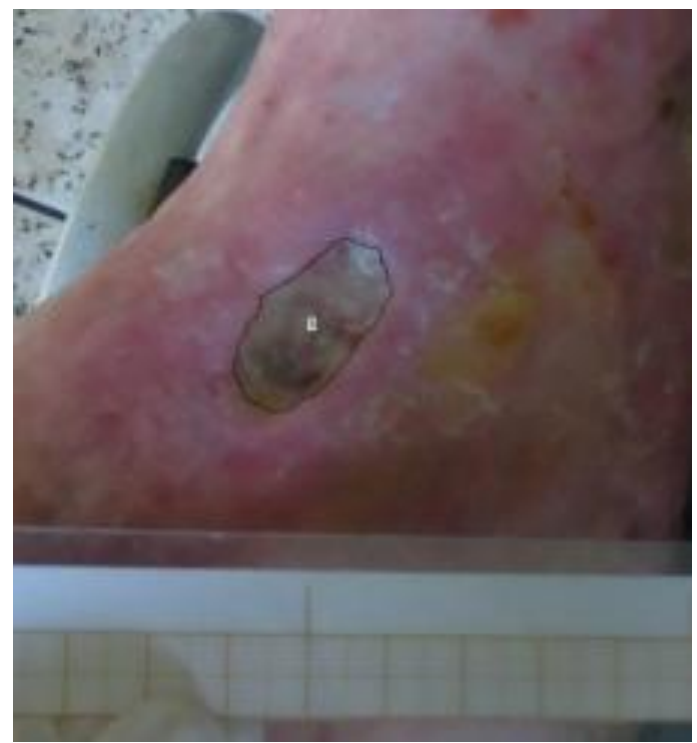

Figura 68: 60 dias após inicio do tratamento 
No final dos atendimentos houve aumento da área da úlcera e isso provavelmente ocorreu pelo fato do paciente ter sua diabetes descompensada e não apresentar higiene adequada, além do quadro infeccioso local que é indicativo de antibioticoterapia. Outro fator possivelmente relacionado a este resultado foi que a membrana de CB com própolis não teve grande aderência no local. É importante ressaltar que este caso foi tratado até 75 dias (área total de $4,034 \mathrm{~cm}^{2}$ ) e não até 90 dias como previsto, por impedimento médico (Figura 69).

Segundo Blumberg et al. (2012), o desenvolvimento de úlceras do pé diabético é resultado dos efeitos progressivos e acumulativos das complicações de um quadro diabético antigo.

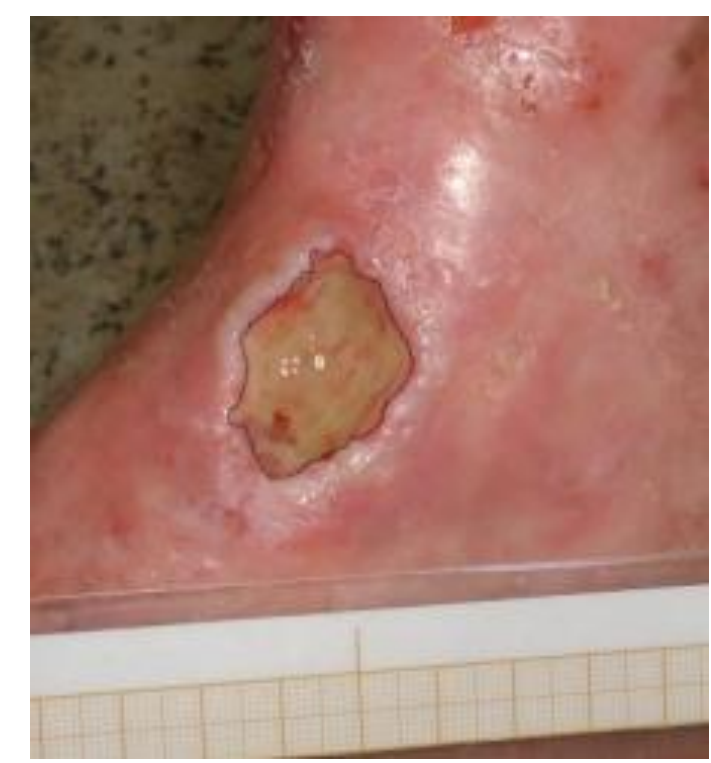

Figura 69: 75 dias após inicio do tratamento

Em indivíduos com diabetes mellitus, as úlceras permanecem num estado inflamatório crônico e obtém fracasso na sua cicatrização ordenada. O fluxo contínuo de células inflamatórias e a produção permanente de seus mediadores químicos causam desequilíbrio da protease e seus inibidores, o que dificulta a síntese e remodelamento da matriz extracelular que são essenciais para uma cicatrização normal. A diabetes prejudica a função dos neutrófilos e macrófagos, incluindo a aderência celular, a quimiotaxia, a fagocitose e a produção/secreção de citocina. Os queratinócitos e fibroblastos de úlceras diabéticas mostram capacidade de migração reduzida, resposta a fatores de crescimento diminuída e aumento da apoptose. A complexidade da fisiopatologia da úlcera do pé diabético é multifatorial 
e necessita de intervenção em vários níveis para acelerar sua cicatrização (BLUMBERG et al., 2012). Para efetividade do tratamento de úlceras diabéticas, é importante que haja controle dos fatores sistêmicos, como manutenção da glicemia ideal para evitar o surgimento e/ou piora da úlcera.

As características hidrofílicas e hidrofóbicas dos materiais são muito importantes nestas interações entre células e substrato (ANSELME, 2000). Geralmente, as células aderem mais fortemente a superfícies de materiais mais hidrofílicos (YANG; ZHAO; CHEN, 2002). A membrana de CB com própolis é hidrofóbica, e isso poderia explicar o fato da dificuldade de adesão ao leito da úlcera, já que esta pode, em muitos casos, estar coberta por exsudato inflamatório. A falta de adesão pode sugerir que a membrana de CB com própolis não teve sua atuação plena com relação aos seus efeitos antimicrobiano e anti-inflamatório.

Outro fator que pode ter influenciado o insucesso do tratamento e aumento da úlcera G5b, seria a própria aplicação do LBI, pois segundo o trabalho de Nussbaum et al (2003), o crescimento de algumas colônias de bactérias pode ser estimulado pelo LBI. Esses autores utilizaram laser de $810 \mathrm{~nm}$ com variação na irradiância de $0,015 \mathrm{~W} / \mathrm{cm}^{2}$ ou $0,03 \mathrm{~W} / \mathrm{cm}^{2}$ em uma única sessão, em bactérias gram-positivas e gram-negativas, com várias doses. Foi observado por esses autores que houve aumento no crescimento de Pseudomonas aeruginosa na irradiância de $0,015 \mathrm{~W} / \mathrm{cm}^{2}$ e diminuição em $0,03 \mathrm{~W} / \mathrm{cm}^{2}$, em dose de $1 \mathrm{~J} / \mathrm{cm}^{2}$ e com o Staphylococcus aureus, para ambas irradiâncias, o crescimento não foi diferente comparado com o controle em qualquer exposição. Esses dados podem sugerir ao presente trabalho que, neste caso específico, a aplicação do LBI estimulou o crescimento bacteriano na úlcera, aumentando sua área total.

\subsection{CONSIDERAÇÕES FINAIS}

A condição nutricional é um fator decisivo na evolução do processo cicatricial devido à especificidade de elementos. As proteínas favorecem a resposta inflamatória e a síntese de colágeno com a remodelação da úlcera; os carboidratos e as gorduras fornecem energia; a vitamina $\mathrm{K}$ atua no processo da coagulação; 0 complexo B favorece a ligação do colágeno; o zinco auxilia na proliferação celular e epitelização; e o manganês, o cobre, o magnésio e as vitaminas $A$ e $C$ também contribuem na síntese do colágeno (ALCANTARA; ALCANTARA, 2009). Desta 
forma, estes fatores nutricionais poderiam explicar o fato de que algumas úlceras apresentaram dificuldade de cicatrização (G1a, G4c e G5b), pois pôde-se notar que o tipo de alimentação destes indivíduos é sugestivo de não-ideal.

Os casos encontrados neste trabalho não tiveram a possibilidade de ser comparados entre os grupos por vários fatores: heterogeneidade das amostras, "n" insuficiente, tempo existente da úlcera diferente, tamanho variado das úlceras, etiologia variada e condições sistêmicas específicas. Não foi possível também realizar uma avaliação e/ou caracterização dos sintomas de dor local devido ao fato da maioria dos pacientes tratados apresentarem um estado de consciência mental confuso.

Também é importante mencionar que o tratamento de úlceras crônicas não se limita apenas a aplicação de determinado recurso ou agente cicatrizante. É necessário entender seu mecanismo de origem e tomar as devidas providências para que este seja anulado a fim de obter sucesso no tratamento.

A reparação de um tecido exige um ambiente propício para a formação de colágeno, angiogênese e epitelização da úlcera. Fatores sistêmicos e locais podem interferir nesse processo como: idade, doenças neurológicas que levam a imobilidade e falta de sensibilidade, doenças oncológicas, insuficiência renal, doenças vasculares e arteriais, diabete mellitus, estado nutricional pobre, sistema imunológico debilitado, tabagismo, falta de assepsia da úlcera, infecção e escolha equivocada do tratamento.

Antes de iniciar o tratamento de uma lesão, faz-se necessário realizar uma avaliação desta úlcera, pois toda e qualquer proposta de tratamento deve levar em conta não só a lesão a ser tratada, mas o paciente com suas características e necessidades. A escolha do tratamento para cada úlcera realizada neste estudo foi feita aleatoriamente, como proposto na metodologia, no entanto, no decorrer dos atendimentos, acompanhamento e experiência durante todo o período, foi possível notar as diferenças entre cada caso e sugerir medidas terapêuticas adequadas.

No quadro geral, houve cicatrização total de $67 \%$ das úlceras tratadas neste trabalho; uma úlcera teve sua área final aumentada provavelmente por fatores sistêmicos (diabete descompensada e infecção bacteriana) e o restante das úlceras acompanhadas apresentou reepitelização parcial, porém próxima à cura total.

Assim sendo, dentre os recursos utilizados neste estudo e os casos apresentados, pode-se sugerir um tratamento ideal para cada tipo de úlcera e perfil 
do paciente (condições sistêmicas). $O$ tratamento para úlceras arteriais sugere-se 0 tratamento com membrana de CB pura associado à aplicação do LBI para incremento da analgesia; o tratamento das úlceras venosas, a utilização da membrana de CB pura; no caso de úlceras de pressão que apresentam grande dificuldade na permanência da membrana de CB poderia ser mais efetiva a aplicação do LBI; casos de úlceras por trauma poderiam ser tratados tanto com membrana de CB pura ou CB com própolis ou ainda associados ao LBI. No caso de úlceras diabéticas estas poderiam ser tratadas através da associação da membrana de CB pura e LBI. Diante de algum evento infeccioso, poderia se optar pela associação entre membrana de $\mathrm{CB}$ com própolis e o $\mathrm{LBI}$, mas para esse fim, é necessário adequar a produção da $\mathrm{CB}$ com própolis a fim de melhorar sua flexibilidade e adesão ao leito da ferida.

Portanto, as membranas de CB pura e com própolis são materiais promissores no tratamento de úlceras crônicas de difícil cicatrização. Ainda, para um melhor resultado, sugere-se a associação do LBI às membranas de CB. $O$ uso exclusivo do LBI é consagrado na literatura e indicado para casos de úlceras crônicas.

Por fim, essas considerações enfatizam a importância de mais trabalhos com tratamentos tecnologicamente mais avançados para úlceras crônicas, como a membrana de celulose bacteriana associada a outros recursos curativos, já que não há na literatura trabalhos publicados com experimentação clínica desse tipo. 


\section{CONCLUSÃO}

Segundo os objetivos e a metodologia empregada podemos concluir que:

1. Todos os tratamentos (CB pura, $\mathrm{CB}$ com própolis, $\mathrm{LB}$, CB pura + $\mathrm{LBI}, \mathrm{CB}$ com própolis + $\mathrm{LBI}$ ) foram eficazes no incremento da cicatrização de úlceras crônicas;

2. Pode se sugerir que os curativos de membrana de celulose bacteriana pura e com própolis associados ao LBI são recursos promissores no tratamento de úlceras de diversas origens; o LBI também auxiliou o controle da dor local, segundo relatos.

Com base na avaliação detalhada da úlcera a ser tratada é necessário fazer a escolha adequada do recurso a ser utilizado, levando em consideração o paciente como um todo e suas condições sistêmicas.

São necessários mais estudos com testes da membrana de celulose bacteriana envolvendo seres-humanos com úlceras de pele para que seja possibilitada uma comparação entre os tratamentos aplicados. A perspectiva de novos curativos de celulose bacteriana também é real para o tratamento de úlceras crônicas de pele. 


\section{REFERÊNCIAS BIBLIOGRÁFICAS ${ }^{1}$}

1. ALBERTINI, R. et al. Anti-inflammatory effects of low-level laser therapy (LLLT) with two different red wavelengths $(660 \mathrm{~nm}$ and $684 \mathrm{~nm})$ in carrageenaninduced rat paw edema. Journal of Photochemistry and Photobiology B: Biology 89; 50-55, 2007.

2. ALBERTINI, R. et al. Effects of different protocol doses of low power galliumaluminum-arsenate (Ga-Al-As) laser radiation $(650 \mathrm{~nm})$ on carrageenan induced rat paw edema. J. Photochem. Photobiol. B 74 (2-3) 101-107, 2004.

3. ALCANTARA, C.; ALCANTARA, V.C.S. Healing process of wounds caused by erysipelas in a patient suffering from diabetes mellitus. Com. Ciências Saúde. 20(2):173-184, 2009.

4. ANSELME, K. Osteoblast adhesion on biomaterials. Biomaterials, v.21, n.7, p.667-681. 2000.

5. ATALLA, R.H. Cellulosis. Madison: [s.n], 1999. Cap 1, p. 529-598.

6. BÄCKDAHL, $H$. et al. Mechanical properties of bacterial cellulose and interactions with smooth muscle cells. Biomaterials, v.27, n.9, p.2141-9. 2006.

7. BANKOVA, V.; POPOV, S.; MAREKOV, N. On the chemical composition of some propolis fraction with antiviral action. Acta Microbiol. Bulg., 23: 52-57, 1988.

8. BERNARDES, C.H.A. et al. Clinical experience assessing 284 cases of erisipela. An bras Dermatol, Rio de Janeiro, 77(5):605-609, 2002.

9. BEVILACQUA M. et al. Natural resin associantion such incense and propolis in zootechnology. Agriculture, Ecosystems and Environment 62 247:252, 1997.

10.BLUMBERG, S.N. et al. The role of stem cells in the treatment of diabetic foot ulcers. Diabetes Research and Clinical Practice 96; 1-9, 2012.

11.BONVEHI, J.S.; COLL, F.V.; JORDA, R.E. The composition, active components and bacteriostatic activity of propolis in dietetics. JAOCS. 71: 529-532, 1994.

\footnotetext{
${ }^{1}$ De acordo com a Associação Brasileira de Normas Técnicas. NBR 6023.
} 
12.BROWN, R. M.; WILLISON, J.H.M.; RICHARDSON, C.L. Cellulose biosynthesis in Acetobacter xylinum: visualization of the site of synthesis and direct measurement of the in vivo process. Proc. Natl. Acad. Sci. USA., v. 73, p. 4565-4569, 1976.

13. CABRAL, L.M. et al. Experimental model of double wounds on the rats back, in order to study the skin cicatrization process on rat treated with cellulose coat. Acta Cir Bras [serial online] Vol 18 Special Edition, 2003.

14. CAETANO, K.S. et al. Phototherapy improves healing of chronic venous ulcers. Photomed Laser Surg. 27:111-8, 2009.

15. CALLAM, M. et al. Chronic Ulceration of the Leg: extension of the problem and provision of care. British Medical Journal 290 1855-1856, 1985.

16. CAMPANA, V. et al. Effects of diclofenac sodium and He:Ne laser irradiation on plasmatic fibrinogen levels in inflammatory processes. J. Clin. Laser Med. Surg., New York, v. 16, n. 6, p. 317-320, 1998.

17. CIZMARIK, J.; MATEL, I. Examination of the chemical composition of propolis. I. Isolation and identification of the 3,4-dihydroxycinnamic acid (caffeic acid) from propolis. Experientia. 26: 713, 1970.

18. CIZMARIK, J.; MATEI, I. Examination of the chemical composition of propolis. II. Isolation and identification of 4-hydroxy-3-methoxycinnamic acid (ferulic acid) from propolis. J. Apic. Res., 12: 63-65, 1973.

19. CZAJA, W. et al. Microbial cellulose - The natural Power to heal wounds. Biomaterials 27 145-151, 2006.

20.CZAJA, W. et al. In Cellulose: Molecular and Structural Biology; Brown, R.M.; Jr.; Saxena, I. M., Eds.; Springer Dordrecht : The Netherlands, 2007a.

21. CZAJA, W. et al. The Future Prospects of Microbial Cellulose in Biomedical Applications. Biomacromolecules 8(1):1-12, $2007 \mathrm{~b}$.

22. DEMIR, H. et al. Comparison of the effects of laser and ultrasound treatments on experimental wound healing in rats. Journal of Rehabilitation Research \& Development, 41(5):721-728, 2004. 
23. DONINI, I.A.N. et al. Biossíntese e recentes avanços na produção de celulose bacteriana. Eclet. Quím. vol.35 no.4 São Paulo, 2010.

24. ERASLAN G.; KANBUR M.; SILICI S. Evaluation of propolis effects on some biochemical parameters in rats treated with sodium flouride. Pesticide Biochemistry and Physiology 88. P.273:283, 2007.

25. EUROPEAN PRESSURE ULCER ADVISORY PANEL: Guidelines on treatment of pressure ulcers. EUPAP Review v. 1, p. 31-33, 1999.

26. FALCÃO, S.C.; NETO, J.E.; COELHO, A.R.B. Incorporation by host tissue of two biomaterials used as repair of defects produced in abdominal wall of rats. Acta Cirúgica Brasileira - v. 23 (1), p.01:06, 2008.

27.FRADE, M.A.C et al. Natural-biomembrane dressing and hypersensitivity. An Bras Dermatol.86(5):885-91, 2011.

28. FRADE, M.A.C et al. The vegetal biomembrane in the healing of chronic venous ulcers. An Bras Dermatol. 87(1):45-51, 2012.

29. FRANCO S.L. et al. Avaliação Farmacognóstica de própolis da região de Maringá. Rev. Bras. Farmacog.,v. 9, p. 1:10, 2000.

30.FRANKS, P.J. et al. Community Leg Ulcer Clinics: Effect on Quality of Life. Phlebology 9 83-86, 1994.

31. FURTADO, K.A.X. Úlceras de Perna - Tratamento baseado na evidência. Nursing Portuguesa, v.1, 2003.

32. GEYER, U. et al. Formation, derivatization and applications of bacterial cellulose. Int. J. Biol. Macromol., v. 16, p. 343-347, 1994.

33. GIMÉNEZ, J.C.M.; GUTIÉRREZ, M.G.; PUYA, R.J. Tratamiento de las úlceras crônicas. Actas Dermosifiliogr. 96(3):133-46, 2005.

34.GOMES, F.G; FRADE, M.A.C; FOSS, N.T. Skin ulcers in leprosy: clinical and epidemiological characteristics of patients. An Bras Dermatol. 82(5):433-7, 2007. 
35. GRANGE, J.M.; DARVEY, R.W. Antibacterial properties of própolis (bee glue). J R Soc Med v.83, p. 159-160, 1990.

36. GUARINI, L. et al. Growth inhibition and modulation of antigenic phenotype in human melanoma and glioblastoma multiforme cells by caffeic acid phenethyl ester (CAPE). Cell. Mol. Biol., v. 38, p. 513-27, 1992.

37. GUTKNECHT, N.; EDUARDO, C.P. A odontologia e o laser: atuação do laser na especialidade odontológica. $1^{\text {a }}$ ed. São Paulo: Quintessence editora, 2004. $320 p$.

38. GUZZARDELLA, G. A. et al. Laser stimulation on bone defect healing: an in vitro study. Lasers Med. Sci., London, v.17, n.3, p.216-20, 2002.

39. HELENIUS, G. et al. In vivo biocompatibility of bacterial cellulose. J. Biomed. Mater. Res. 76A, p. 431-438, 2006.

40. IKENO, K.; IKENO, T.; MIYAZAWA, C. Effects of propolis on dental caries in rats. Caries Res. v. 25, p. 347-351, 1991.

41. KARU, T. et al. Irradiation with He-Ne laser increases ATP level in cells cultivated in vitro. J. Photochem. Photobiol. B., Lausanne, v. 27, n. 3, p. 219 223, 1995.

42. KAYAOGLU, G. et al. Antibacterial Activity of Propolis versus Conventional Endodontic Disinfectants against Enterococcus faecalis in Infected Dentinal Tubules. JOE. v 37, n 3, 2011.

43. KAZEMI-KHOO, N. Successful treatment of diabetic foot ulcers with low-level laser therapy. The Foot 16, 184-187, 2006.

44. KEDZIA, A. Sensitivity of anaerobic bacteria to the ethanol extract of propolis. Phitotherapie, 6: 4-8., 1990.

45. KLEMM, D. et al. Bacterial Synthesized cellulose - artificial blood vessels for microsurgery. Progress in Polymer Science, v.26, p.1561:1603, 2001.

46. KLEMM, D. et al. Cellulose: Fascinating Biopolymer and Sustainable Raw Material. Angew CHem Int Ed Engl 30;44(22):3358-93, 2005. 
47.KOŁODZIEJCZYK, M.; POMORSKI, L. Final Report on the Realization of the Grant No. 7 from the Polish State Committee for Scientific Research (in Polish); 1999.

48. MENEZES, $\mathrm{H}$. et al. Antibacterial properties of propolis and products containing propolis from Brazil. Apidologie 28: 71-76, 1997.

49. MESTER, E. et al. The biomedical effects of laser application. Lasers Surg Med, New York, v. 5, n. 1, p. 31-39, 1985.

50.METZNER, J. et al. On the antimicrobial activity of propolis and propolis constituents. Pharmazie, 34: 97-102, 1979.

51. MINATEL, D.G. et al. Phototherapy promotes healing of chronic diabetic leg ulcers that failed to respond to other therapies. Lasers Surg Med. 41:433-41, 2009.

52.MORISON, M.; MOFFATT, C. A Colour Guide to the assessment and management of Leg Ulcers. Second edition. London: Mosby, 1994.

53. NEWAIRY, A.S.A. et al. Propolis alleviates aluminium-induced lipid peroxidation and biochemical parameters in male rats. Food and Chemical Toxicology. $\mathbf{P}$. 01:06, 2009.

54. NICOLAU, R. A. Effect of low-power GaAIAs laser (660nm) on bone structure and cell activty: an experimental animal study. Lasers Med. Sci., London, v.18, p. 89-94, 2003.

55. NUSSBAUM, E.L.; LILGE, L.; MAZZULLI, T. Effects of low-level laser therapy (IIlt) of $810 \mathrm{~nm}$ upon in vitro growth of bacteria: relevance of irradiance and radiant exposure. J Clin Laser Med Surg. 21(5):283-90, 2003.

56. OLIVEIRA R.C.S. et al. Biosynthetic cellulose induces the formation of a neoduramater following prenatal correction of meningomyelocele in fetal sheep. Acta Cirúrgica Brasileira - Vol 22 (3). p.01:08, 2007.

57.ONO, E.; WATABE, O.; YAMANAKA, S.; inventors; Ajinomoto Co. Inc., assignee. Substitution material for living body texture. Japanese patent, 1989, 27 Nov. Acessível em: http: //www. delphion.com 
58.PEREIRA, M.C.M.C. et al. Influence of $670 \mathrm{~nm}$ low-level laser therapy on mast cells and vascular response of cutaneous injuries. Journal of Photochemistry and Photobiology B: Biology 98; 188-192, 2010.

59. PRETEL, $H$. et al. Avaliation of wound healing using the laser and pomade of esther ricinoleic acid. J. Dent. Res., Chicago, v.81, sp. iss. B, p.B91, 2002.

60.RIBEIRO, M.A.G. et al. Morphological analysis of second-intention wound healing in rats submitted to $16 \mathrm{~J} / \mathrm{cm}^{2} \lambda 660-\mathrm{nm}$ laser irradiation. Indian $\mathbf{J}$ Dent Res, 20(3), 2009a.

61.RIBEIRO, M.A.G. et al. Immunohistochemical assessment of myofibroblasts and lymphoid cells during wound healing in rats subjected to laser photobiomodulation at $660 \mathrm{~nm}$. Photomedicine and Laser Surgery, 27:1, 2009b.

62.ROCHA; J.A.; MIRANDA, M.J.; ANDRADE, M.J. Abordagem terapêuticas das úlceras de pressão - Intervenções baseadas na evidência. Acta Med Port, 19:29-38, 2006.

63. ROCHA, L. et al. Otimização do processo de extração do própolis através da verificação da atividade antimicrobiana. Ver. Bras. Farmacog., v. 13, p. 71:74, 2003.

64. RUSSO , A.; LONGO, R.; VANELLA, A. Antioxidant activity of propolis: role of caffeic acid phenethyl Ester and galangin. Fitoterapia 73. 1:9, 2002.

65.SADER, H.S.; DURAZZO, A. Terapia antimicrobiana nas infecções do pé diabético. J Vasc Br vol 2, nํ 1, 2003.

66. SAMSON, D.J.; LEFEVRE, F.; ARONSON, N. Wound-Healing technologies: low-level laser and vaccum-assisted closure. AHRQ Publication, n 111, 2004.

67.SANTOS, F.A. et al. Antibacterial activity of Brazilian propolis and fractions against oral anaerobic bacteria. J. Ethnopharmacology, p.1:7, 2002.

68.SANTOS, J.B. et al. Avaliação e tratamento de feridas - Orientações aos profissionais da saúde. Hospital das Clínicas de Porto Alegre - RS. Disponível em: http://www.lume.ufrgs.br/bitstream/handle/10183/34755/000790228.pdf?sequence=1 
69. SCHINDL, A. et al. Diabetic neuropathic foot ulcer: successful treatment by lowintensity laser therapy. Dermatology. 198(3):314-6, 1999.

70.SCHNEIDEWIND, E.M. et al. Identification of isolated from propolis, antimicrobial active ingredient. Pharmazie, 34: 103-106., 1979.

71.SILVA, J.C et al. Antimicrobial activity, phenolic profile and role in the inflammation of própolis. Food and Chemical Toxicology 50. 1790-1795, 2012.

72.SKOPIN, M.D.; MOLITOR, S.C. Effects of near-infrared laser exposure in a cellular model of wound healing. Photodermathology, Photoimmunology e Photomedicine, 25:75-80, 2009.

73. THEIN, H. et al. Health status utilities and the impact of pressure ulcers in longterm care residents in Ontario. Qual Life Res. 19:81-89, 2010.

74.THIRUGNANASAMPANDAN, R.; RAVEENDRAN, S.B.; JAYAKUMAR, R. Analysis of chemical composition and bioactive property evaluation of Indian própolis. Asian Pacific Journal of Tropical Biomedicine. 651-654, 2012.

75. VANHAELEN, M.; VANHAELEN-FASTRÈ, R. Propolis I. Origine, micrographie, composition chimique et activity therapeutique. J. Pharm. Belg., 34: 253-259, 1979.

76. VOWDEN, K.R.; VOWDEN, P. Arterial disease: reversible and irreversible risk factors. Journal of Wound Care. 5(2) Feb 89-90, 1996.

77.WILLIAMS, D.F.; ALI, S.A.M.; DOHERTY, P.J. Molecular biointeractions of biomedical polymers with extracellular exudate and inflammatory cells and their effects on the biocompatibility in vivo. Biomaterials, v. 15, n. 10, 1994.

78.WOISKY, R. G.; SALATINO, A. Analysis of própolis: some parameters and procedures for chemical quality control. J Apicultural Res, v. 37, p. 99:105, 1998.

79.YANG, X.; ZHAO, K.; CHEN, G.Q. Effect of surface treatment on the biocompatibility of microbial polyhydroxyalkanoates. Biomaterials, v.23, n.5, p.1391-7. 2002. 
80. Yasukawa, A.; Ohrui, H.; Koyama, Y.; Nagai, M.; Takakuda, K. The effect of low reactive-level laser therapy (LLLT) with Helium-Neon laser on operative wound healing in a rat model. J. Vet. Med. Sci. 69(8): 799-806, 2007. 


\section{APÊNDICE A - Termo de Consentimento Livre e Esclarecido}

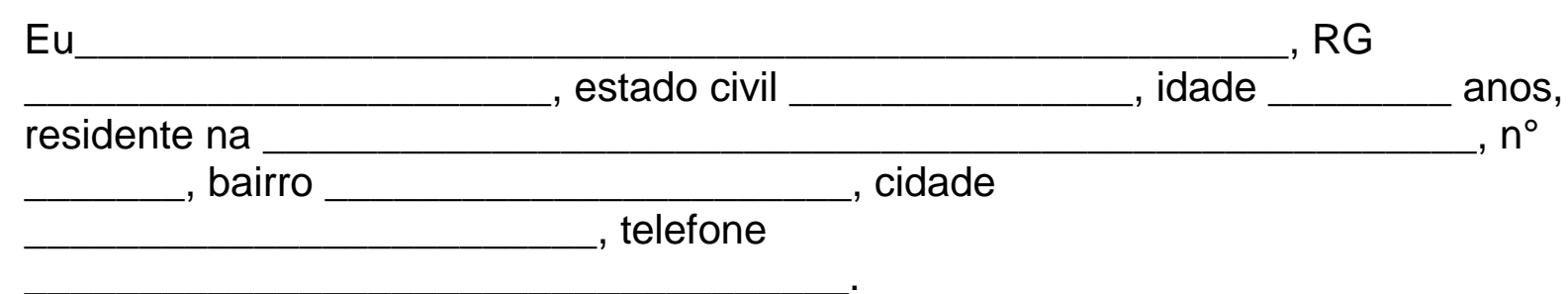

\section{Declaro ter sido esclarecido sobre os seguintes pontos:}

1. O trabalho tem por finalidade testar qual dos curativos a seguir é o mais eficaz no tratamento de úlceras que são difíceis de serem curadas: Membrana de Celulose Bacteriana (CB) Pura ou com Própolis, associados ou não com o laser de baixa intensidade (LBI).

2. Ao participar desse trabalho estarei contribuindo para testar qual tratamento é melhor para ajudar na cura da minha úlcera;

3. Para essa pesquisa, não terei que doar nenhum tipo de material biológico, e somente serei submetido a aplicação de (a escolha do tratamento será feita pelo pesquisador);

4. A minha participação como voluntário deverá acontecer até o fechamento da úlcera ou até no máximo 90 dias;

5. Os riscos que corro são muito pequenos, que incluem: desconforto ou pequeno inchaço na região da aplicação do tratamento, pequena reação alérgica e/ou infecção do local. Fui esclarecido que o pesquisador tomará todos os cuidados para que nada disso ocorra, mas se qualquer situação desse tipo ocorrer, ele irá interromper a aplicação e tomará os devidos cuidados para restabelecer minha saúde;

6. Os curativos de membrana de CB utilizados serão esterilizados e os materiais utilizados para a aplicação dos curativos serão descartáveis. A aplicação do laser será feita sem haver contato com a úlcera;

7. Deverei voltar ao ambulatório todas as vezes em que houver solicitação dos pesquisadores desse projeto; 
8. Os procedimentos aos quais serei submetido não provocarão danos morais, físicos, financeiros ou religiosos;

9. Não terei nenhuma despesa ao participar desse estudo;

10.Poderei deixar de participar do estudo a qualquer momento, avisando os pesquisadores, sem nenhum prejuízo ou piora da úlcera;

11. Meu nome será mantido em sigilo, assegurado assim a minha privacidade e se desejar, deverei ser informado dos resultados dessa pesquisa;

12. Permitirei que as fotografias de minha úlcera sejam divulgadas no trabalho, afim de demonstrar a evolução do tratamento;

13. Qualquer dúvida ou solicitação de esclarecimentos, poderei entrar em contato com a equipe científica pelo telefone: (16) - 92280522 (Fernanda Sanchez).

Diante dos esclarecimentos prestados, concordo em participar do estudo "Avaliação do processo de reparação tecidual em úlceras crônicas utilizando curativos de Celulose Bacteriana associados ou não à Laserterapia", como voluntário.

Se houver inabilidade por parte do paciente em assinar esse termo, algum responsável o fará:

Nome do responsável:

$\mathrm{RG}$ anos, residente na

$\mathrm{n}^{\circ}$ , bairro telefone estado civil , idade cidade de. de 20 


\section{ANEXO A - Parecer de Aprovação do Comitê de Ética em Pesquisa com Humanos}

\section{Centro Universitário de Araraquara}

\section{COMITÊ DE ÉTICA EM PESQUISA}

Parecer do projeto sob o protocolo no 1096/10 de 19 de abril de 2010.

Título do Projeto: “Avaliação do processo de reparação tecidual em úlceras crônicas utilizando curativos de Celulose Bacteriana Pura ou com Própolis associados ou não à Laserterapia".

Pesquisadora responsável: Fernanda Sanchez

Orientadora:

Profa. Dra. Ana Maria Minarelli Gaspar

\section{PARECER}

0 projeto apresentado tem o objetivo comparar a eficácia da aplicação de membrana de celulose bacteriana, isoladamente ou em mistura com própolis, associadas ou não a aplicação de laser de baixa intensidade, em pacientes portadores de úlceras de pressão. A amostra experimental constará de 50 voluntários, na faixa etária de 20 a 50 anos. Os curativos contendo a membrana bacteriana pura ou associada com própolis serão substituídos semanalmente, até o momento da cura das úlceras ou até o período máximo de 90 dias. 0 número de aplicações do laser será calculado para cada paciente. O período de intervalo entre as seșsões será de 72 horas. No projeto foram relacionados todos os riscos previstos aos sujeitos da pesquisa e benefícios.

A análise do projeto demonstra sua adequação às diretrizes do Conselho Nacional de Saúde/Ministério da Saúde, regulamentadoras das pesquisas envolvendo seres humanos.

Assim, sou de parecer favorável à execução do projeto conforme apresentado para análise, considero-o APROVADO para execução.

Ao seu término os responsáveis deverão apresentar relatório final, conforme modelo padronizado pelo CEP-UNIARA.

Araraquara, 06 de maio de 2010.

Relator/Parecerista

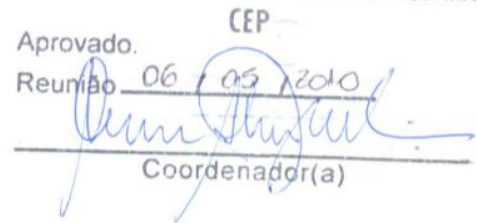

